\title{
NINETEENTH QUARTERLY PROGRESS REPORT \\ BASELINE GAS TURBINE DEVELOPMENT PROGRAM
}

JULY 31, 1977

COMPILED AND EDITED BY:
This report was prepared as an account of work sponsored by the United States Government of work United States nor the United States Deparither the Energy, nor any of their employees, Department of contractors, subcontrecton, or their employy of their any warranty, express or implied, of assumees, makes liability or responsibility for the accuracy a somes legal ot usefulness of any information, appacy, completeness process disclosed, or represents that its use product or infringe privately owned rights.

\section{CONTRACT NO. EY-76-C-02-2749.A0O4}

PREPARED FOR

ENERGY RESEARCH AND DEVELOPMENT ADMINISTRATION

DIVISION OF TRANSPORTATION ENERGY CONSERVATION

SUBMITTED TO

DAVID G. EVANS, DEPUTY MANAGER

GAS TURBINE PROJECT OFFICE

NASA LEWIS RESEARCH CENTER

$\sum \beta$ 


\section{DISCLAIMER}

This report was prepared as an account of work sponsored by an agency of the United States Government. Neither the United States Government nor any agency Thereof, nor any of their employees, makes any warranty, express or implied, or assumes any legal liability or responsibility for the accuracy, completeness, or usefulness of any information, apparatus, product, or process disclosed, or represents that its use would not infringe privately owned rights. Reference herein to any specific commercial product, process, or service by trade name, trademark, manufacturer, or otherwise does not necessarily constitute or imply its endorsement, recommendation, or favoring by the United States Government or any agency thereof. The views and opinions of authors expressed herein do not necessarily state or reflect those of the United States Government or any agency thereof. 


\section{DISCLAIMER}

Portions of this document may be illegible in electronic image products. Images are produced from the best available original document. 
Progress is reported for a program whose goals are to demonstrate an experimental Upgraded gas turbine powered automobile which meets the 1978 Federal Emissions Standards, has significantly improved fuel economy, and is competitive in performance, reliability, and potential manufacturing cost with the conventional piston engine powered, compact-size American automobile.

Activity during this nineteenth program quarter has continued to emphasize development towards correcting a power deficiency in the Upgraded Engine. Tests using a higher reaction compressor turbine wheel design improved power $7 \%$. Accordingly, overall power deficiency has now been reduced to $25 \%$ from an original value of $43 \%$. Up to $5 \%$ further improvement is expected from modifications to compressor components now in progress. However. the achievement of program goals will require a modification to the original compressor turbine design constraints and an overall redesign. Similar action may also be required of the power turbine section. Action on the compressor turbine is currently underway. Other progress items of significance during this past quarter include a thorough documentation of engine operating characteristics by testing of the NASA instrumented engine, and initiation of regenerator flow uniforming efforts. 


\section{TABLE OF CONTENTS}

Page

Introduction

Progress Summary

Detailed Progress Statement by Task

Task 3.1 Support to ERDA

Car 624

3

Car 667

3

Car 671 - Baseline

Public Interest Cax - Car 649

Task 3.2 Support to NASA 4

Engine Test

NASA Rigs

Task 5.7 Hydromechanical Transmission 5

Task 7.2-7.3 Upgraded Engine Procurement and Assembly 5

Procurement

Assembly status

Summary Test Iog

Engine 1

Engine 4

Task 7.5 Corrective Development

Compressor

Compressor-Tuxbine

Power Turbine Interstage and Exhaust Diffuser

Overall Turbine Section Assessment 20

Turbomachinery Test Rigs . 20

Power Turbine Test Rig 20

Non-Regenerative Engine Rig $\quad 21$

Vortex-Nozzle Flow Analysis Rig 22

Regenerator Flow Distribution $\quad 22$

Engine Combustors $\quad 23$

Gas Bearing Development $\quad 24$

Integrated Control System 25

Optional P.T.N. Actuator $\quad 26$

V.I.G.V. Actuator 26 
TABLE OF CONTENTS (COn't)

Task 8.2 Build Upgraded Vehicles

Car 130

Car 385

Vehicle - Systems Procurement

Car 386

Task 10 Improved Automotive Gas Turbine (IAGT)

Design Study

Task 10.1 Establish Near Term Technology

Task 10.3 Development of Sinterable Silicon Carbide Technology

Task 10.4 Evaluation of Ceramic Materials Having Potential for High Temperature Turbine Engine Applications

Future Activities
Page

26

26

26

26

26

27

27

28

28

29

iv 


\section{INTRODUCTION}

This Baseline Gas Turbine Development Program is being sponsored by the Heat Engine Systems Branch, Division of Transportation Energy Conservation (TEC) of the Energy Research and Development Administration (ERDA) - ERDA was established in January, 1975, in accordance with the Energy Reorganization Act of 1974. Prior to this reorganization. TEC had been the Advanced Automotive Power Systems Division (AAPSD) of the Environmental Protection Agency (EPA).

The overall mission of AAPSD, which resulted in the generation of this particular program, had been to evaluate, develop and demonstrate automotive powerplant concepts potentially superior, in the area of emissions control and fuel economy, to the standard spark ignition reciprocating engine. A principal area of activity has been the automotive gas turbine. Programs were first initiated in this area early in 1971 when several contracts were let for the development of low emissions combustion, and for studies related to cycle optimization, engine arrangement, and cost to manufacture. Additionally, EPA enlisted NASA for technical support to these programs through an inter-agency agreement.

This Baseline Engine program was implemented on November 22, 1972, with the signing of a contract between EPA and Chrysler Corporation. Specific goals of this program were to demonstrate in 1976 an experimental gas turbine powered automobile which would meet the 1978 Federal Emissions Standards, have significantly improved fuel economy and be competitive in performance, reliability and potential manufacturing cost with the conventional piston engine powered, standard-size American automobile.

Structurally, this program was made up of three parts: documentation of the existing automotive gas turbine state-ofthe-art; (2) conduction of an extensive component improvement program; and (3) utilization of the improvements in the design, and building of an Upgraded Engine capable of demonstrating program goals.

Because this program was relevant to the mission of ERDA's TEC Division, the program remained intact following the change in administration from EPA to ERDA. 
Chrysler Corporation's Sixth Genexation Gas Turbine Engine, having been selected as representative of the state-of-the-art at the beginning of this program, was used as the Baseline Engine. This was a 4:1 pressure ratio regenerative engine with variable power turbine nozzles which meets the $.4 \mathrm{HC}, 3.4 \mathrm{CO}, 3.0 \mathrm{NOx}$ grams $/ \mathrm{mile}$ original 1975 emissions standards. The Baseline vehicles were intermediate-size, 4mdoor sedans modiried to accept the turbine engines.

As is shown in the detailed Program Plan (Appendix B), Baseline documentation (Tasks 1 and 2) was accomplished early in the program. Also as shown, the Baseline Engine improvement work (Tasks 5 and 6) has been completed except for a small Task 5.7 effort for verifying an MTI hydromechanical CV transmission concept. Efforts still to be completed include building and testing Upgraded Engines and vehicles, Task 7 anc 8 , and a recently implemented improved automotive gas turbine design study, Task 10.

With respect to Tasks 7 and $8_{\theta}$ initial running of the Upgraded Engine took place on July 13, 1976. This engine, though mechanically sound, started out about $43 \%$ deficient in power. The principal problem has been low exficiencies of the aerodynamic subsystems resulting from compromises made to satisfy packaging/ interface and other design constraints. Changes in the compressor and compressor turbine along with some reductions in leakage and pressure drop have currentily reduced the power deficiency to about 25\%. ERDA is continuing to support corrective development of this engine to provide a sound base for their advanced engine programs. Current efforts continue to focus on the design and testing of modified compressor and compressor turbine components.

Chrysler Corporation efforts on this program are being managed and coordinated by the Research section of the Engineering Office. Those who have contributed directly in writing this report include C. Belleau, A. Billington, Bo Chapman, J. Corwin, F. Dosenberger, C. Elliott, Jo Engel, T。Golec, J. Gross, Jo Gumaer, F. Hagen, E. Kohl, Jo Lewakowski, C. Mader, Do Musgrave, T. Nogle, R. Pampreen, L. Pritchard, No Sparks, R. Swiatek, and E. Trieskey. 
- A special bodied 2-door coupe and an Upgraded Engine is being prepared as a public interest car.

- Power Plant 5-4 was completed, checked-out at Chrysler and installed at NASA where fully instrumented engine tests were started.

- The initial installation of a ceramic regenerator and seals was made in the NASA regenerator test rig.

- Chrysler testing of the pump-motor module of the MTI hydromechanical transmission has been concluded. Analysis of the data is nearing completion.

- Purchase orders for the three remaining vehicle engines have been placed except for those parts expected to be significantly changed in the corrective development tests.

- Upgraded Engines 1, 2, and 4 are undergoing various corrective development tests on the dynamometer. Engine power at $80 \%$ speed is now about $75 \%$ of program goal.

- Tests using a higher reaction compressor turbine wheel design improved power $7 \%$ 。

- An initial determination was made of the non-uniformity of flow through the low pressure regenerator.

- Material studies for the improved automotive gas turbine (IAGT) desigh study are nearly complete. 
TASK 3.1 SUPPORT TO ERDA

Car 624 - Baseline

Deactivated and stored.

\section{Car 667 - Baseline}

This vehicle continued in service at ERDA headquarters, Washington, D.C. until early June at which time it was replaced by Car 671 . The replacement was prompted by reported low oil pressure. Routine maintenance was performed on both the engine and vehicle. The gas generator compressor flowpath areas were dirty with soot and were cleaned.

The low oil pressure experienced in the car was traced to the pump housing. Bench checking revealed that the regulator was bypassing at $60 \mathrm{psi}$ instead of $90 \mathrm{psi}$ which is typical. A replacement housing was installed. The engine oil cooler exhibited high pressure drop and was also replaced.

The oil sump rebuild included the replacement of a worm wheel due to excessive weax. Indications are that hot oil temperature may have been the cause of wear.

\section{Car 671 - Baseline}

The vehicle was reactivated as a replacement for car 667. Engine removal was required to service the steering system, and during this interim, the engine was reconditioned. The vehicle is in service at ERDA headquarters, Washington, D。C.

\section{Public Interest Car - Car 649}

A Chrysler LeBaron 2-Door Coupe, scheduled as the fourth prom gram vehicle, was modified and an Upgraded Engine mock-up was installed. The front-end sheetmetal and grill are being replaced with distinctively styled fiberglass parts. These represent a design concept in which the extremities would be made of soft energy absorbing materials. Figure 1 shows the clay modeling in 
process on the actual vehicle. Styling modifications will be completed on August 22 with the engine installation to be finalized about the third week of September. The vehicle is scheduled for display at the october 3 rd coordination meeting.

Because the Upgraded Engine premixed combustor control is not yet fully developed, a "Baseline" style diffusion flame combustor will be used to insure reliable starting.

\section{TASK 3.2 SUPPORT TO NASA}

\section{Engine Test}

Assembly of Power Plant 5-4 was completed and the engine was installed in Chrysler Cell $12 \mathrm{~S}$ for, initiai shakedown and evaluation of all instrumentation. In the meantime, Power Plant 3-1 from $12 \mathrm{~S}$ was delivered to NASA-Lewis for use in completing their test cell installation and initial cell shakedown. During the week of June 27, Power Plant 5-4 was delivered to NASA-Lewis and Power Plant $3 \times 1$ was returned to Chrysler.

During this period, a complete ECU system with diagnostic panel break-out box and turbine control panel and cabling were delivered to and discussed with NASA personnel. The unit allowed NASA to run the loaned engine. Power Plant 3-1, to check out their facilities.

Technical support to NASA by Ultra has been provided for within the existing contract. One service call to NASA-Lewis was required this quarter to troubleshoot an abort start condition on the Chrysler engine. The problem was identified as ignition noise impressed on the fuel feedback signal. The start fuel schedule is closed loop and this exceptionally high ficticious signal resulted in a false metering valve signal that shut off fuel. The problem could be circumvented by unplugging the fuel flow feedback sensor which allowed the engine to start and run on open loop fuel command. Rerouting of the ignition wires solved the problem. The problem reappeared with the NASA engine, Power Plant 5-4, when it replaced Power plant 3-1. NASA is, therefore, running open loop during starting until the problem is again resolved.

\section{NASA RigS}

A visit was made to NASA-Lewis to make the initial installation of a ceramic regenerator and seals in the regenerator test rig. 
Parts are being assembled for shipment to NASA for use in their Upgraded Engine gas generator and power turbine test rigs. These include three each of compressor turbine and power turbine wheel castings, a burner vortex, a compressor turbine nozzle and a set of power turbine nozzle components.

\section{TASK 5.7 HYDROMECHANICAL TRANSMISSION}

Research Laboratory testing of the pump-motor module of the MTI hydromechanical transmission has been concluded. The data has been submitted to Chrysler's Performance Analysis Engineering Department for their evaluation of the effect of this transmission on the acceleration and the EPA composite cycle economy of a $38951 \mathrm{lb}$. test weight vehicle. A preliminary study based on MTI module data indicated that the CV hydromechanical transmission offers only a $4 \%$ Urban Cycle economy gain and about 2\% Composite Cycle improvement when compared with a standard three-speed automatic transmission with torque converter lockup. Four-speed automatics with T/C lockup promise greater economy than these MTI CV transmission results. However, the economy potential of the CVT is believed to be somewhat better than indicated in the initial analysis and a reevalua. tion is now in progress using some additional data taken to more accurately define low power operating characteristics.

Typical module performance characteristics are shown in Figure 2 which indicates that efficiencies above $85 \%$ are attainable over a wide range of input speedmpower combinations. Most efficient operation results with both pump and motor set for maximum displacement ( $1: 1$ module ratio), although performance declines were not serious when module ratios were held in the $0.4: 1$ to 2.0:1 range. Module efficiencies under 20 to $60 \mathrm{mph}$ road load conditions fell in the 61 to $65 \%$ range, but overall road load transmission efficiencies were much higher (75 to 90\%) because of the split hydraulicmechanical power transmitting design.

Tape recordings have been made of module vibration character istics covering a wide range of speed load combinations including road load and Urban Cycle accelerating conditions. Frequency analysis of these tapes is in progress.

TASK 7.2 to 7.3 UPGRADED ENGINE PROCUREMENT AND ASSEMBLY

Procurement

All parts for the three additional vehicle engines have been ordered with deliveries due to be completed in mid-August. Some 
parts, vortex and compressor cover, have not been ordered" due to possible design changes resulting from the corrective development program.

Delivery of engine housing castings continues to be slow due to metallurgical deviations. Three castings were delivered in May. Although zyglo and x-ray were acceptable, the castings were scrap due to an unacceptable nodular count. Two additional housings (from a pour of four) are acceptable and will be machined. Four more castings are scheduled to be delivered the first week in August.

\section{Assembly Status}

The Figure 3 tabulation summarizes the status of power plant assemblies. Because no new machined engine housings were received since the last report, the display engine housing had to be used for the Chrysler regenerator flow fixture program. Assembly of Power Plant 8-10 for the Pubiic Interest Car has begun.

The Figure 4 tabulation shows the parts and delivery schedule for the corrective development program.

\section{Summary Test Log}

For the purpose of reference documentation, following is a log of the various tests run during this reporting period:

\section{Engine 1 (Power Plant 3al)}

During this quarter, five builds of this power plant were evaluated with 22 full sets of data recorded. Total engine time is now 160.0 houxs, with 18.2 hours logged this quarter. This includes 2.9 hours of testing at the NASA-Lewis Research Center. Test highlights are as follows:

\section{Builds AI and $A J$ Runs 345 to 358}

Tested axial inlet. Starting accomplished by impinging shop air on impeller vanes. About onehalf point compressor efficiency improvement (see Task 7.5 Compressor) 。 Burner flashback occured at 95\% speed. 
Build AK, Runs 359 to 361

An assembly of non-critical available parts was made for shipment to NASA-Lewis to check out their new engine cell. However, engine surge at $80 \% \mathrm{Ngg} 100^{\circ} \mathrm{F}$ under match, due to use of 14-channel $+4^{\circ}$ taper enlarged throat diffuser, precluded shipping.

Build AL, Runs 362 to 366

Reassembled with standard $14^{\circ}$ diffuser and documented performance to $90 \%$ speed where burner/fuel control operated slightly unstable, but schedule did not permit time to correct. Engine delivered to NASA-Lewis on May 13, 1977.

\section{Build AM (NASAnLewis Cell Checkout)}

The checkout of the NASA-Lewis facility was successfully concluded after a total of 2.9 hours of testing.

When returned to Chryslex, the engine was completely disassembled ( 160 total running hours). Aside from some areas of loose or eroded insulation, and a worn worm wheel, it was in good condition. On rebuild, the basic engine housing is being adapted for a fully instrumented interstage. Its designation is now Power Plant 3-9 (engine housing 3 - housing assembly 9). Instrumentation will include three each of P6T, T6T, P63T, P6.3S, P7T, and 6P7S. In addition, a grid with eight thermocouples will measure exhaust diffuser $\{T 7.5)$ temperature distribution, and eight static pressure taps will be placed at the exhaust diffuser discharge. Also, extensive compressor diffuser static tap instrumentation will be monitored with a 24-channel manual Scanivalve system now being completed. An oil jet is being added for the regenerator drive worm.

Engine 2 (Power Plant 2-3)

During this quarter, 16 engine builds were tested with 191 sets of data recorded. Engine time is now 161.8 hours, of which 54.9 were logged this quarter. Test highlights are as follows: 
Build T, Runs 161 to 164

Standard engine build to check out new P6T probes.

Build $U_{2}$ Runs 165 to 173

Tested machined .8 scale Baseline CT wheel; signi-

ficant improvement (see Task 7.5. Compressor Turbine).

Builds $V, W$ and $X$ Runs 161 to 285

Conducted power turbine parasitic loss tests. Using the engine dynamometer in the driving mode, driving power versus speed was determined with a dummy power turbine shaft (no disc) and with a shaft and ribbed disc (no blades).

Tests were conducted cold and with the engine operating, except for power turbine blading. The results shown on Figures 5, 6, and 7 , indicate that the losses, including the ribbed windage are not excessive.

Builds $Y$ and $Z$, Runs 286 to 290

Tested an inlet bowl with the hub of the inlet flow path removed. Resulted in flow instability (see Task 7.5. Compressor) . Burner flashback encountered at $90 \%$ speed. Detailed $80 \%$ speed data taken from 1200 to 2000 rpm prop shaft speed.

Build AA, Runs 297 to 310

Original inlet reinstalled; 28 channel tl, $4^{\circ}$ taper. tandem de-swirl impeller. .8 scale Baseline wheel. Mod I nozzle retained. Data recorded up to $95 \%$ speed without surge or flashback. Sinop air added to regenerator cover at $90 \%$ but unable to reach design $\mathrm{P}_{6}$ total without surge. During repeat tests, flashback occurred at 95\%. At the completion of the testing, green chrome oxide dye was injected into the $\mathrm{P}_{4}$ cavity at $80 \%$. On teardown, a light radial impeller rub and a moderate turbine tip rub were found. These were attributed to the surges at $90 \%$ combined with tight build clearances of $.006^{\prime \prime}$ and $.007 "$ " respectively. 
Build $A B_{,} A C$ and $A D$ Runs 311 to 329

A gas generator was installed with standard parts except for the 14-channel compressor diffuser being modified with a $4^{\circ}$ taper to the throat (Mod 2 taper) and with cut-back deswirl vanes. Also installed was an extended burner, a view-port burner cap, and a zirconia-lined burner tube. The cut-back deswirl ring improved the surge margin of this particular diffuser, but no signiricant power increase was noted. Burner wall temperature was reduced and the turbine inlet temperature profile improved. Several minor changes were made to the burner to reduce flashback (see Task 7.5 Combustor)。

\section{Build AE}

An attempt was made to check out a NASA experimental burner discharge temperature grid. Even with a slow cool start ( 28 seconds, $1715^{\circ} \mathrm{F}$ max vortex $\mathrm{T}_{5}$ ), the environment proved too severe with one thermocouple melting and the grid buckling.

Build $A F_{2} A G$ and $A F_{\text {R }}$ Runs 330 to 346

Initial test of a one piece all-aluminum impeller; no improvement (see Task 7.5 Compressor) assembled with corrective development hardware - Mod 1 CTN, Mod 1 CTW, 28 channel $+1^{\circ}$ diffuser with $4^{\circ}$ taper and tandem deswirl. Burner extension still installed. The all-aluminum impeller required special proximity pickups in place of the magnetic speed pickups normally used. The burner extension was removed and the burner leaned out to reduce burner tube temperature and allow high speed testing. Shop air was added to the regenerator cover to obtain surge points. It was found that, at higher speeds, substantially less added cycle air was required to induce surge, and at $95 \%$ the engine surged without added air, even $50^{\circ}$ under T8 match (see Task 7.5 Compressor).

Build AI Runs 347 to 351

Twenty-eight channel $+1^{\circ}$ diffuser replaced with 14 channel S/N 5, with Mod 2 taper and cut-back single 
deswirl stage. Surge margin again improved (Reference Build $A B$ ), but surge was still encountered at $95 \%$. Performance comparable to previous build with the 28 channel $+1^{\circ}$ diffuser/deswirl. This onepiece diffuser/deswirl is now being reworked to permit its evaluation in tandem assembly and with 28-channel diffusers. On disassembly, the Mod 1 machined CTW was found to have two blades with a short crack in the trailing edge near the blade root. The trailing edges of both blades were ground away and blade profiles re-contoured.

This engine is currently being rebuilt with essentially the same components as Build $\mathrm{AH}$, except for substitution of a standard compressor turbine nozzle installed in place of the Mod 1 CTN. In support of vehicle development, this build will also be used to determine power turbine nozzle braking characteristics. Other items scheduled for near term testing include the machined Mod 1.1 and Mod 2 nozzles, the cast Mod 1 nozzle, and the 18-18 splitter impeiler.

\section{Engine 4, (Power Plant 5-4)}

The NASA engine was received on May 14, 1977, installed and successfully started May 24, 1977. To protect the engine from possible damage due to melted instrumentation (see Power plant 2-3, Build $A E$, above), a new non-instrumented burner tube and cap were installed. Because the required number of pressure and temperature readings exceeded the test cell readout capability, the engine was tested three full times, each with different instrumentation. Details of the instrumentation are listed on Figure 8. Total engine time was 34.2 hours. Test highlights were as follows:

Builds A to E, Runs 1 to 19

"A" instrumentation. Burner successively developed until engine ran successfully to $100 \%$ speed. Power was typical of other engines prior to installation of corrective development hardware $(26.23 \mathrm{HP}$ at $80 \%)$. 
Build F, Runs 20 to 29

"B" instrumentation

Build G, Runs 30 to 36

"C" instrumentation

Overall performance of this engine is shown on Figure 9. Details of predicted versus measured pressures are shown on Figures 10 and 11. A 50\% speed regenerator hot and cold side temperature map are shown on Figures 12 and 13, respectively.

The engine was removed from the test cell and returned to NASA on June 25, 1977.

\section{TASK 7.5 CORRECT IVE DEVELOPMENT}

The development status of the Upgraded Engine as shown on Figure. 14 has progressed to where power at $80 \%$ speed is about $75 \%$ of program goal. Following is a summary listing of progress to date along with future projections for the three turbomachinery areas:

$$
\text { Date } \Delta \eta
$$

I Compressor Efficiency

- Goal

- 1.26 scale rig

- First engine build

$3 / 76$

1. Fill in inducer-impeller

$8 / 76$

$12 / 76+.01$ gap

2. Single to tandem deswirl vanes

3. 14 to 28 channel diffuser

$2 / 77+.005$

- Current level

$$
3 / 77+.015
$$

4. 24 full blade to 18-18 splitter impeller

5. 2 row axial-l row axial cascade diffuser

$$
9 / 77 \quad(0-.015)
$$

$9 / 77 \quad(0-.015)$

- Future projection 
Date

$\Delta \eta$

$\eta$

I Compressor Turbine Efficiency

- Goal

- First engine build

$8 / 76$

.85

1. Nozzle recontoured to

$4 / 77 \quad 0-.01$ accommodate measured vortex flow I

2. Higher reaction wheel;

$6 / 77 \quad .03-.04$ .8 scale of Baseline

- Current level.

3. Recontoured nozzle II

4. Scaled Baseline nozzle

5. New stage with lower inlet velocities, lower through flow velocities, higher reaction

- Future projection

$\begin{array}{rl}8 / 77 & 0-.03 \\ 10 / 77 & 0-.03 \\ 3 / 78 & .03-.05\end{array}$

$.84=.86$

III Power Turbine Efficiency

- Goal

- First engine build

$8 / 76$

.75

1. Improvement due to gas

$6 / 77 \quad 0-.03$

.63 generator improvements

- Current status

$\begin{array}{ll} & .63-.66 \\ 0-.02 & .59-.68 \\ +.09 & \end{array}$

$\begin{array}{lll}\text { 2. Recontour exhaust diffuser } 11 / 77 & 0-.02 \\ \text { 3. Recontour entire section } 2 / 78 & +.09\end{array}$ for lower through flow velocities

- Future projection

To assure that the corrective designs reflect state-of-the-art technology, use is being made of outside consultants.

Progress details for the various corrective development areas are discussed in the following sections. 


\section{Compressor}

- Inlet

To determine the sensitivity of compressor performance on inlet arrangement, tests were conducted with (I) an axial inlet and (2) a modification to the standard air intake assembly. These configurations are shown in Figure 15. For the axial inlet tests, the standard intake assembly was replaced with a bellmouth-type inlet and bullet nose, similar to the compressor test rig. For the other test, the modification to the standard air intake consisted of removel of the hub-piece of the inlet flowpath. The purpose was to see if this piece was interfering with the entry-flow instead of providing controlled guidance as intended.

The results on compressor efficiency are shown in Figure 16. For the axial inlet, there was less than 0.5 point increase in efficiency from $60 \%$ to $80 \%$ speeds; except at $70 \%$ speed, where the increase was 0.8 point. The trend was similar to that found when clearance was varied in the rig.

For the modified intake, there was less than 0.5 point increase at all speeds tested, but the results were clouded by the fact that the inlet pressure measurements were unstable. The results were further obscured by data uncertainty, with the standard intake measurements varying from 0.1 to 0.6 point in efficiency.

- Impeller

Testing began with an all aluminum integral-bladed impeller. The standard impeller is a two-piece assembly with the major part aluminum but with a short inducer section at the inlet made of steel to withstand the erosive effect of water injection. A gap at the front to rear blading interface has been plugged with silastic since early in the program when testing showed a gain of 1 point in efficiency due to sealing the gap. Uncertainties in blade mating and the quality of the blade shape after sealing led to a decision to establish more clearly the efficiency difference from an integral-bladed impeller. Preliminary data analysis shows no difference in performance between that obtained with the gap filled and the integral impeller. 
As described in the eighteenth quarterly report, power turbine performance has been investigated by injecting shop air downstream of the compressor. Evaluation of power turbine performance near design operating and inlet conditions is made possible by this artificial means of decreasing compressor turbine pressure ratio. In carrying out these tests, however, compressor mass flow is reduced, thereby yielding compressor operating range data. Figure 17 shows surge points encountered with the 28-channel diffuser ( $+1^{\circ}$ : setting) in compaxison with non-surge data taken with the standard 14 -channel diffuser $\left(+1^{\circ}\right.$ setting). The data at $80 \%$ and $100 \%$ speeds indicate that the 28 -channel diffuser should probably be used with the $+2^{\circ}$ setting angle to achieve the intended surge margin. This will be investigated on a future test.

Both the $1.26 \mathrm{x}$ size compressor rig and the engine compressor incorporate the same radial/axial diffuser. However, as reported in the seventeenth quarterly, the rig showed a .795 overall efficiency with an integral impeller whereas the comparable engine compressor efficiency (two-piece impeller with axial gap filled) was .769; with one major difference being the collector configuration. The rig has a large uniform collector while the engine is constrained to the somewhat constricted threelobe arrangement.

Two approaches are being studied to minimize the influence of the collector on the diffuser:

1. reducing the Mach number going into the radial-toaxial bend.

2. shortening the axial diffuser to decrease any collector wall interference effect.

To lower the Mach number in the bend, rectangular and conical channel diffusers and a double-row cascade diffuser were studied.

The results showed that the lowest Mach number before the bend would be obtained with the cascade diffuser. The Mach numbers were $0.32 ; 0.31$ and 0.28 , for the rectangular, conical and cascade diffusers, respectively. The swirl-removing capability of the cascade diffuser permits lower Mach numbers to be achieved than with the channel configurations. The exit swirl is 
$61^{\circ}$ and $53^{\circ}$ for the channels and cascade diffuser, respectively. Also, the cascade diffuser presents less blockage to the bend. Complete diffusion in a single channel is not possible because of the size limitation of the collector. Complete diffusion down to the required collector inlet Mach number (.05 to .l) would require a channel diffuser twice as long as the present channel. The size limitation makes it necessary to have deswirl vanes beyond the bend, regardless of diffuser configuration. The cascade study showed the possibility of completing the diffusion with a single deswirl vane row. This places the diffuser exit aimost twice as far from the collector wall.

On the basis of lower Mach number and swirl to the bend and the increased distance from the compressor exit to the collector wall, a cascade diffuser design was initiated and completed. The cascade configuration is shown in side and front views in Figure 18. The diffuser consists of a tandem vane-row in the radial direction followed by a bend to axial with a third vane-row. The first two rows have 20 vanes each, with solidities of 1.17 and 1.02 respectively。 The combined solidity is 1.96 . The solidities are based on the linear chord in the radial plane and the spacing at the average radius between leading edge and trailing edge. The solidity of the third row is 2.0 . The diffuser exit plane is 8.9 exit-plane heights from the plenum. wall, contrasted to 3.23 heights for the original design. The radial-plane vane profiles are conformally transformed NACA 65-series sections. The first-row vanes are NACA 65-(04) 04 sections, and the second-row vanes are NACA 65-(08) 04 sections. The third-row vanes are $65-(21) 10$ sections.

Compressor-Turbine

- .8x Scale Baseline Wheel Tests

It was stated in the last quarterly report that an $0.8 x$ scale of the Baseline Engine compressor-turbine rotor was being prom cured as an alternate test configuration. This move was based primarily on the comparison of the flow visualization results at $80 \%$ speed for the Upgraded and Baseline Engine rotors. The results of chrome oxide injection showed heavy deposit on the suction surface of the Upgraded Engine rotor and virtualiy none on the Baseline Bngine rotor. The fundamental difference between the two rotors is that the Baseline wheel has a mianradius reaction of $42 \%$ while that of the Upgraded wheel is $23 \%$. The specification of low reaction for the original Upgraded 
design was made to minimize the Mach number and swirl into the power turbine section. As described in the twelfth quarterly. this velocity must remain relatively low for VIGV power augmentation to be effective. Blademtomblade calculations showed mean-radius values of suction surface diffusion parameters of 0.195 and 0.247 for the Upgraded and the Baseline rotors, respectively. Although the diffusion parameters are comparable and within a generally recommended limit of 0.25 , the meanradius diffusion gradient ${ }^{l}$ values were 0.721 and 0.433 for the Upgraded and Baseline rotors, respectively. With the generally recommended limit being 0.5 , it was presumed that the dye deposit reflected the high rate of diffusion.

Test results showed an average powex increase of $14 \%$ over an engine built with a standard rotor. The maximum change was $19 \%$ at $50 \%$ speed and a minimum of $9 \%$ at $70 \%$ speed. The turbine pitchline-based efficiency improved an average of 4 points. The maximum change was 5 points at $60 \%$ speed, and the minimum was 3 points at $80 \%$ speed. The inconsistencies can probably be attributed to differences in leakage and data scatter, based on overall observation of the test results.

The reduction of the mean-radius diffusion gradient is presumed to be the major reason for performance improvement. Vector diagram analysis reflecting the lack of nozzle endwall turning discussed in the eighteenth quarterly report showed, however, that further improvements might be gained. Specifically, this showed a mean-radius incidence angle of $5^{\circ}$ and values near the tip near $8^{\circ}$. At the hub the incidence was computed to be $-8^{\circ}$. It was felt that less positive and negative values of incidence angle would slightly improve efficiency. In addition, the previous blade-to-blade analysis showed diffusion gradients of 1.6 and 1.0 at the hub and tip, respectivelyo for the $0.8 \times$ scale rotor. The values for the Upgraded rotor were computed to be 0.9 and 1.5 at the hub and tip. respectively. consequently, it was felt a need existed to design a stage with a lower diffusion gradient and incicence angle over the entire span as the next step in this sequence.

Reference 1: The Design and Performance Analysis of AxialFlow. Turbines. Volume I - Theory and Practice of Design Report No. 1174-1. Northern Engineering and Research Corporation. 
The rotor design was begun, completed, and is currently being reviewed. The nozzle design was just being completed at the time of this report. A blade-shape and channel comparison with the other rotors is shown in Figure 19. A table of design parameters is shown in Figure 20 and the vector diagrams are shown in Figure 21. The design is characterized by a spanwise variation in work caused by lack of endwall turning, an increase in solidity (througin increased axial chord) and a vector diagram suitable for augmentation, and a small relaxation of allowable polar moment of inertia.

\section{- Engine Pitchline Data Analysis}

A summary of pitchline efficiency data available to date for the compressor-tuxbine is plotted in Figure 22. The efficiency is based on overall. work and ideal work at the mean radius. The overall work is computed from compressor and parasitic power and turbine weight flow infered from turbine inlet temperature and pressure, nozzle exit static pressure and nozzle flow characteristic from calibration in a flow rig. The ideal work is computed from the upstream total pressure measured in the vortex chamber and three meanmradius values of exit total pressure.

Overall, pitchline data shows little correlation with improvement in engine power. When leakage was arbitrarily assumed constant, the correlation improved.

The data of Figure 22 show an efficiency loss of about 4 points with the Mod 1 nozzle. In contrast, an engine power gain of 2.1 horsepower was measured on another set of data, not included in Figure 22. This result was obtained by comparing the test results of engine Power Plant 3-1 AB (Standard Nozzle) versus Power plant 3-1 AG (Mod I Nozzle, Bent). This was the only comparison availabie with virtualiy the same compressor configuration (tapered versus untapered versions of the 28-channel diffuser). Unfortunately, no efficiency comparison was available since pitchline total pressures were not measured on these engine builds. In another comparison, an average increase of 3.7 horsepower was achieved with the $0.8 x-s c a l e$ rotor of the Baseline Engine (Power Plant-2-3, Build U 
versus Build Q). This represents an increase of 2.5 points; the average change in "pitchline" exficiency was 3.7 points. These results are much more consistent than those for the change in nozzle design.

The Mod 1 nozzle vane was installed with the trailing edge located circumferentially a half-pitch distance away from the trailing edge of the standard nozzle vane. For a further attempt to resolve the data inconsistencies, the circumferential position of the three fixed total pressure probes was measured and related to nozzle trailing edge position. The results are shown in Figure 23. At two positions, the probes are in line with the standard nozzle trailing edges and the third probe is in line with the Mod 1 nozzle trailing eage. such positioning suggests that, relative to wake pitch spacing, high efficiency data could come from between-wake sampling and low-efficiency data could come from near-wake sampling. During the analytical calculations, it was found that a change of $0.67 \mathrm{psi}$ in rotor-exit total pressure changes efficiency by 4 points. Since it is likely that the circumferential variation of efficiency is more than 4 points (cf. Reference 2, for instance), direct comparison of efficiency levels of the two nozzle designs tends to be suspect.

In summary, it is not possible with the data available to date to precisely determine the efficiency of the compressor-turbine from pitchline total-pressure measurements alone. A circumferential sampling will be needed to make this evaluation and to accurately reflect efficiency changes with design modifications. Even the use of the tip static pressures to estimate efficiency is no better than the accuracy of the pitchline total-pressure sampling. Taking the average of the data sets in Figure 22, the efficiency could be anywhere from 0.77 to 0.81 . An accurate value will require more engine instrumentation (a pitchline wake-rake at least) or rig resting. Even though an accurate value of efficiency cannot be established. the data suggests that the stage could be 3 to 6 points below program goal at $80 \%$ speed.

Power Turbine Interstage and Exhaust Diffuser

Instrumentation installed on the NASA engine, Power Plant 5-4. permitted an evaluation of the static-pressure-recovery and loss-coefficient charactexistics of the interstage duct and exhaust diffuser. The results for the interstage duct are shown on Figure 24. Comparison with off-design estimates is also shown in each figure.

2. Okapuu, U.: Some Results from Tests on a High Work Axial Gas Generator Turbine. ASME Paper 74-GT-81. 
The interstage duct is about 16\% below recovery goals, but this may be the result of higher blockage than anticipated as evidenced by higher Mach numbers for the test results compared to the off-design estimates. The off-design estimates were based on the expectation of achieving the recoveries reported by Sovran and Klomp for straight wall annular diffusers. An improvement in recovery would be expected when exit blockage is reduced through development of the compressor turbine stage.

The results for the exhaust diffuser are shown in Figure 25, as a function of gas generator speed. The static pressure recovery is only about $28 \%$ of program goal. The loss data show that this must be primarily due to excessive losses. The absolute loss if 2.5 times the estimated value; the loss coefficient is over 5 times the estimated value. This is consistent with lower-than-design exit Mach number, which is due to the power deficiency.

These results may be pessimistic, as shown by Figure 25, which is a plot of diffuser characteristics with power turbine speed for conditions at $80 \%$ gas generator speed. The figure shows that the effectiveness and recovery increase significantly up to the intended peak-power rotaticnal speed (44,500 RPM) and as design swirl is approached (dashed lines). The swirl values were computed from an off-design analysis from Run 41. However, the maximum values are still much lower than the off-design estimates.

These estimates were based on the creare tests of a Chrysler A-907 in-house exhaust diffuser design. Those results showed recovery values of 0.56 at zero swirl to 0.47 at $35^{\circ}$ swirl for the Mach number levels shown in Figure 26. The area ratio for the A-907 diffuser was 2.2 and for the Upgraded Engine is 2.1. The recovery of the A-907 diffuser dropped below 0.3 at $30^{\circ}$ swirl for a single-sided exit. This nay be part of the reason for the miss in recovery of the Upgraded Engine exhaust diffuser.

Preliminary test results from Creare for the Upgraded Engine exhaust diffuser show a recovery of 0.24 at zero swirl with and without a free runner. The results are close to engine values for $10^{\circ}$ of swirl. The engine values may be lower due to blockage differences between rig and engine. It is notable that the recovery measured in the Creare tests did not depend on the presence of wakes from the free runner, up to 20,000 rpm. Tests will be conducted up to 40,000 rpm to further confirm these results. 


\section{Overall Turbine Section Assessment}

Following discussions by Chryslex, NASA and various consultants, it was concluded that to bring the compressor turbine stage up to design goals:

1. A significantly lower velocity vortex or dump plenum inlet should be used to minimize endwall effects entering the first stage nozzle and rotor.

2. The annulus area of the stage be increased at least 15 percent, probably requiring a relaxation of the stress criteria originally imposed.

3. The velocity trianges be modified to increase discharge swirl from $-5^{\circ}$ to about $-20^{\circ}$, thereby allowing a higher reaction wheel design.

4. Blading be designed within conservative diffusion limits and utilizing an efficiency distribution in line with typically measured endwall decrements.

A corrective action program in line with these conclusions is currently being formulated.

Discussions and assessments with respect to the power turbine area are currently in progress.

\section{Turbomachinery Test Rigs}

As discussed in the Eighteenth Quarterly Report, three turbomachinery test rigs are being built at Chrysler in support of the corrective development program:

1. A regenerative power turbine rig

2. A non-regenerative engine rig

3. A vortex nozzle flow test rig

\section{Power Turbine Test Rig}

The need for an accurate assessment of overall power turbine performance is crucial to the corrective development program. A power turbine test rig would provide early identification of problem areas, and a test bed for development work. This 
performance assessment cannot be accomplished with engine test data since gas generator performance is deficient, degrading power turbine inlet conditions. The choice of a regenerative rig was both so as to be able to provide a proper non-symmetrical downstream exhaust diffuser discharge and for expediency, since use could be made of a standard engine housing. greatly reducing design and procurement time.

An early installation of the rig made during test cell modifications is shown in Figure 27. A cross section of the rig is illustrated in Figure 28. Final assembly of the rig has been delayed because of a procurement delay of the inlet swirl vane assembly. This part is currently due in on August 17. 1977, and, after it clears inspection, final buildup and rig installation can comnence.

The combustor of this rig is an as-released unit mounted axially ahead of the interstage. An extra $61 \mathrm{~mm}$ of length is added between the dilution holes and the interstage inlet to insure uniform distribution.

The H.P. 305A data acquisition system has been incorporated into the regenerative power turbine rig test cell. The system has been programmea to acquire data (minimam on line reduction) and prepare it for detailed reduction. A program has been written to perform the detailed data reduction. Routines to compute leakage and mechanical losses will be integrated into the program when rig data becomes available.

\section{Non-Regenerative Engine Rig}

This rig will provide a compressor and compressor turbine test bed (full scale) for additional diagnostic and aerodynamic development. Information obtained from this rig will resolve differences in performance between rig (1.26 scale) and engine compressors. The uncertainty of regenerator leakage, experienced with engine tests, will be eliminated with this non-regenerative rig. Provisions will be made for more detailed instrumentation, which should allow more prem cise component evaluation.

Materials needed for longalead procurement have been purchased. Layout and detail work are continuing. Figure 29 illustrates the non-regenerative test rig configuration.

The released combustor is not satisfactory for this fixture because it must operate with a cold air inlet (which would 
not vaporize the fuel). Therefore, it is being designed with a "Baseline" type of dropletmdiffusion burner which should need only minimal development for this application.

\section{Vortex-Nozzle Flow Analysis Rig}

This rig will allow exploration of circumferential and radial gradients not possible in the proposed rigs or the engine. More detailed data will be possible than present capabilities permit, and the influence of the vortex configuration on nozzle performance can be carefully analyzed.

Procurement of long lead items is in progress. Detailing is nearly complete.

Figure 30 is a schematic of the cold flow rig. Probe radial setting (from hub) is controlled with an adjusting wheel。 Probe yaw and circumferential position are set using actuators. This rig should be operational by November. 1977.

\section{Regenerator Flow Distribution}

- High Pressure Side Flow Rig

The fixture schematic is shown on Figure 31 . It consists of an engine housing with blockec opening for the variable nozzle, a. gas generator without rotating components placed in the first stage cavity and a ceramic regenerator with seals. A regenerator cover closes the circuit. Since only the high pressure side $\left(P_{3}-P_{4}\right)$ of the regenerator is being investigated, the air is allowed to escape out of the $P_{4}$ zone to the atmosphere. The air is pumped by an electric blower such as to duplicate engine Reynolds number (also $\Delta P / P_{v}$ ). Typically, data surveys are being taken at conditions duplicating idle, $80 \%$ and $100 \% \mathrm{~N}_{\mathrm{GG}}$.

The explorations instrumentation consists of plug probes on the downstream surface of the core measuring the stagnation pressure at the upstream core surface. An initial survey indicated difficient flow near the rim. Modifications to the cover to uniform the flow are being worked out using modeling clay as a filler. 
Testing began on a scale model of the IP side of the regenerator core. This testing is being conducted to investigate core flow distribution as well as exhaust diffuser recovery. The early test data show the majority of flow in the area of the exhaust diffuser shadow on the regenerator core. Preliminary results are shown in Figure 32 .

The top of the figure shows contours of local velocity relative to an average velocity computed from the mass flow, local density and flow area. The bottom of the figure shows the variation of mass flow distribuiion with radius. The mass flow percentages indicate the local percent of mass flow passing through a ring of width 0.101 inch at any given radius.

The plots indicate improvement in core flow distribution as swirl angle (as shown in Figure 33) increases. Test results show no change with or without a free runner at the inlet to the exhaust diffuser. However, the results do show an increase of exhaust diffuser recovery from about 0.20 to about 0.30 in the absence and presence of the runner, respectively. Full review of the data is in progress.

\section{Engine Combustors}

Modifications to burner cover insulation contour. premixer inner swirler, and fuel injector details appears to have greatly reduced the tendency to flash back into the premixer. However, a 3\% pressure drop is still necessary to maintain sufficiently lean operation to avoid excessive burner liner temperatures at $100 \%$ speed. Work will continue, on a low priority basis, toward achieving the goal of $2 \%$ pressure drop.

An 8.75 inch long burner extension was tested on Power Plant 2-3. Seven gas thermocouples at the extension discharge into the vortex showed typical spreads ( $T_{\text {Maximum }}-\mathrm{T}_{\text {Minimum }}$ ) of $50^{\circ} \mathrm{F}$ at idle up to $100^{\circ} \mathrm{F}$ at $80 \% \mathrm{~N}_{\text {gg }}{ }^{\circ}$ However, because of the additional mixing permitted by the extension, the spread between the three nozzle inlet $\mathrm{T}_{5}$ thermocouples was reduced from $125^{\circ} \mathrm{F}$ to $30^{\circ} \mathrm{F}$ at $80 \%$.

A redesign of the torch nozzle support has greatly improved the purging at shut-down and eliminated soft-soot formation 
which had been shorting the spark pling. service on NASA Power Plant 5 4 and Car 386, with retrofit parts on order for all engines.

Quotes have been received from several vendors for ceramic burner tubes. No orders have been initiated pending evaluation of price, material, and delivery time quoted.

\section{Gas Bearing Development}

Funding has been authorized for Phase 3, Tasks 1-4 of the extended MTI program. Also included were funds for bearing procurement under Phase 5. The Phase 3 tasks cover studies to establish oil bearing damper clearance and air bearing clearance tolerances, work with elastomer spring arrangements, and evaluation of new air bearing lubricants.

Testing resumed at MTI with runs up to design speed with .006 oz.in imbalance and $200^{\circ} \mathrm{F}$ oil temperature on an assembly incorporating a standard quad-section elastomer ring, whereas previously the omings had to be scalloped to reduce spring rate. During a subsequent run; the oil bearing damper orbit increased from .0002 to $.0004 \mathrm{in}_{\mathrm{n}}$, and the rotor orbit near the gas bearing also increased and the oil bearing seized. Disasembly showed the gas bearing to be in good condition, but contact had occurred on both the thrust and journal surfaces and pieces of elastomer material from the rings were noted lodged in some of the oil passages of the bearing. The pieces had apparently been cut from the rings during assembly while the rings were passing over a hole for instrumentation wires. It is felt the pieces of elastomer may have interfered with the oil supply to the bearing and caused the failure.

Development work on improved coatings for the gas bearing journal on the gas generator rotor is progressing. Based on engine bearing inspection reports by MTI as covered in the Eighteenth Quarterly and studies by Chrysler, it was determined that a prime factor in journal bearing wear is journal roughness which is a result both of waviness from grinding and coating porosity. Talysurf traces and SEM photomicrographs of the Metco $8 I V F-N$, $\mathrm{Cr}_{3} \mathrm{C}_{2} / 25 \% \mathrm{NiCr}$ coating forming the journal surfaces, were used in these studies and are described below.

Figure $34(a)$ and the photomicrographs on Figure 35 show the large, deep pores in a journal surface coated by a local Chrysler vendor. This surface is typical of that used in Upgraded Engines. The deep voids which would tend to scrape away the soft Mos $_{2}$ coating from the bearing foils are obvious. 
Figure $34(\mathrm{~b})$ and the photomicrographs on Figure 36 show the same coating on the MTI simulator journal as applied by an MTI vendor using a detonation process. This surface is better than that run on engines, but deep voids are still present.

Figure $34(c)$ and the photomicrographs on Figure 37 show coating sample of the same powder as above, plasma sprayed in the Chrysler materials research facility. It is apparent that most of the pores in the denser Chrysler coating are not nearly as deep as those in either the MTI or Chrysler vendor coatings. Talysurf traces and average microfinish numbers bear out this conclusion.

The same Chrysler applied chrome carbide coating described above will be used as a base for "improved Lubricant Studies" to be undertaken under Task 3, Phase 3 of the extended subcontract. Tungsten carbide/cobalt will be a principle candidate for the alternate journal coatings to be evaluated in Task 3 and aluminatitania will also be considered.

\section{Integrated Control System}

The programmable units for the test cells continue to function satisfactorily. However, one unit was replaced when an unexplained shut-down occurred at part throttle. A borderline integrated circuit was replaced and the system bench checked and eventually placed back into service.

All existing PROM boards have been fitted with a new type socket which has superior contact capabilities. Some problems with bridged connections due to this retrofit has caused some delay in putting these boards in service. Additional factory boards are forthcoming which will allow greater flexibility in readily changing test programs for both cell and fixture installations.

One ECU was modified for use with a proximity pickup to allow testing of an all aluminum impeller in Power plant 3-2.

The program for Car 386 was modified to alleviate cold start abort problems experienced when the vehicle returned from the April ERDA Symposium. 
The unit is operating satisfactorily.on the test bench. Development of a suitable control program is in progress.

\section{V.I.G.V. Actuator}

A unit made by Carter will be converted to a two position device to provide power and idle vane positions.

\section{TASK 8.2 BUILD UPGRADED VEHICLES}

Car 130

No activity this period due to other priorities.

Car 385

This vehicle is no longer available for static display as the mock-up engine and vehicle parts were used for system simulation in the Public Interest Car, Car 649. See Task 3.1

Vehicle - Systems Procurement

Ordering of the remaining cars is being delayed. The additional vehicle system parts will be ordered on a lower priority basis.

\section{Car 386}

Transient performance and control data have been documented on the Chassis Rolls. One series of tests to check rotor response gave spurious data and will be remrun after the instrumentation is corrected. The purpose was to gather' as released' rotor acceleration data.

A second series of tests investigated open and closed loop acceleration fuel governing. Closed loop (on fuel flow) had been a proposed method of limiting turbine inlet temperature during rotor accelerations only. The tests showed similar gas generator response on open and closed loop. Some instability on closed loop occurred in trying to increase the response rate of fuel governing. This is due to characteristics of the fuel flow sensor signal as used by the control program. The car control 
program is presently in open loop configuration. Closed loop fuel governing and alternate $\mathrm{T}_{5}$ limiting projects have been postponed.

Some provisions for vehicle/engine systems evaluations have been made. The heater/AC system awaits testing and no major problems are foreseen. The oil cooling system capacity based on informal checks is marginai. Quantitative investigations and improvements will be made as time permits. The air inlet system's noise attenuation is very good the present underhood ventilation provided for E.C.U. cooling allow inlet temperatures up to $10^{\circ} \mathrm{F}$ over ambient at curb idle. The brake servo system functions well but is too sensitive. A solution to this will be pursued.

Lab experience with the present burner systems shows some driveability problems; specifically, inconsistent light ofofs, possible torch/main flameouts, and an unfamiliar characteristic burner noise.

\section{TASK 10 IMPROVED AUTOMOTIVE GAS TURBINE (IAGT) DES IGN STUDY}

Task 10.1 Establish Near Term Technology

- Superalloy - Base Materials

The rough draft of the Task 10.1 study comparing the high temperature properties of the best conventional superalloys with directionally solidified eutectic alloys, axide dispersion strengthened alloys and refractory fiber reinforced superalloys has been written and is being reviewed.

\section{- Refractory Alloys}

The first draft of the state-of-themart review of refractory alloys is being reviewed and edited. Graphs presenting some of the numerical data are being finalized.

- Ceramic Materials Candidates - Property Characterization

High density ceramic material candidates for use in an allceramic gas turbine engine have been characterized. These include silicon carbide, silicon nitride and sialon and their fabrication techniques. A review has been written comparing the high density forms of silicon carbide and silicon nitride produced by hot pressing, sintering, chemical vapor deposition (for SiC) and 
hot isostatic pressing (for $\mathrm{Si}_{3} \mathrm{~N}_{4}$ ). Those materials emerging having the highest potential are sinterable alpha-silicon carbide, and hot isostatically pressed silicon nitride.

Literature survey work to characterize those medium density ceramic candidates is proceeding well. Generilly, these include reaction bonded and recrystallized silicon carbides, reaction sintered silicon nitride, and sialon materials.

Task 10.3 Development of Sinterable Silicon Carbide Technology

Task 10.1 has identified sinterable $\alpha$-silicon carbide as a material with considerable potential in high temperature turbine components. Under Task 10.3 some initial efforts shall be made to develop sinterable $\alpha$-silicon carbide technology with emphasis on the following:

1. Development of fabrication process technology using simulated turbine engine shapes.

2. Characterization of the properties of sintered $\alpha$-silicon carbide.

Most of this effort will be performed by carborundum under subcontract.

Task 10.4 Evaluation of Ceramic Materials Having Potential for High Temperature Turbine Engine Applications

This task will be directed toward the study of promising high temperature material candidates other than Carborundum's sintered $\alpha-S i c$, which have been selected for further characterization. 
In the next quarter, it is anticipated that:

- The public interest car will be completed.

- The NASA testing of the Upgraded Engine and the regenerator rig will be well under way.

- The final analysis report for the MTI transmission will be written.

- Corrective development of the Upgraded Engine will be continuing.

- Upgraded vehicle ceveiopment will be continuing.

- Cycle studies for the IAGT will be well under way. 


\section{EIGURE}

\section{LIST OF FIGURES}

Clay Model for Public Interest Car

Pump-Motor Module Efficiency

Engine status

Corrective Development Parts

Power Turbine windage and Churn Losses - $100^{\circ} \mathrm{F}$ oil Inlet

Power Turbine Windage and Churn Losses - $150^{\circ} \mathrm{F}$ oil Inlet

Power Turbine Windage and Churn Losses - $200^{\circ} \mathrm{F}$ oil Inlet

NASA Engine Instrumentation

BSFC vs. Output Horsepower - Power Plant 5-4

Upgraded Engine - Power Turbine Stage Total and Static Pressures

Upgraded Engine - Power Turbine Stage Total and Static Pressures

Regenerator outlet Grid Station 4 and Regenerator Inlet Grid Station 8

Regenerator outlet Grid Station 9 and Regenerator Inlet Grid Station 3

BSFC vs. Output Horsepower - Power Plant 2-3

Compressor Inlet Tests

Upgraded Engine - Compressor Efficiency Change With Air Inlet Configuration

Upgraded Engine - Static Pressure Ratio

Upgraded Engine Compressor - a. Cascade Diffuser Design

Compressor Tuxbine Rotor - Blade-Shape and Channel Comparisons

Upgraded Engine - Compressor Turbine Redesign 100\% Speed Rotor Characterization

Upgraded Engine - Compressor Turbine Redesign 100\% Speed Vector Diagram

Upgraded Engine - Variation of Measured "Pitchline" Efficiency with Gas Generator speed for Various Engine Builds 
LIST OF FIGURES - Continued

FIGURE

Upgraded Engine - Compressor Turbine Nozzle Positions of Rotor Exit

Upgraded Engine - Turbine Interstage Duct Static Pressure Recovery and Loss Characteristics

Upgraded Engine - Power Turbine Exhaust Diffuser Static Pressure Recovery and Ioss Characteristics

Upgraded Engine - Power Turbine Exhaust Diffuser Variation of Recovery and Loss with $\mathrm{N}_{\mathrm{pt}}$ Early Regenerative Power Turbine Test Rig Installation Cross Section of Regenerative Power Turbine Test Rig Non-Regenerative Engine Test Rig Vortex-Nozzle Cold Flow Test Rig Regenerator Flow Distribution Fixture Upgraded Engine - IP Regenerator Core Flow Distribution Upgraded Engine - Section Through Exhaust Collector Gas Bearing Journal Surface Profiles Gas Bearing Journal Surface - Ground New Journal Gas Bearing Journal Surface - Unworn Section of Used Ground Journal

Gas Bearing Journal Surface - Sample Ground on 600 Grit SiC Paper 


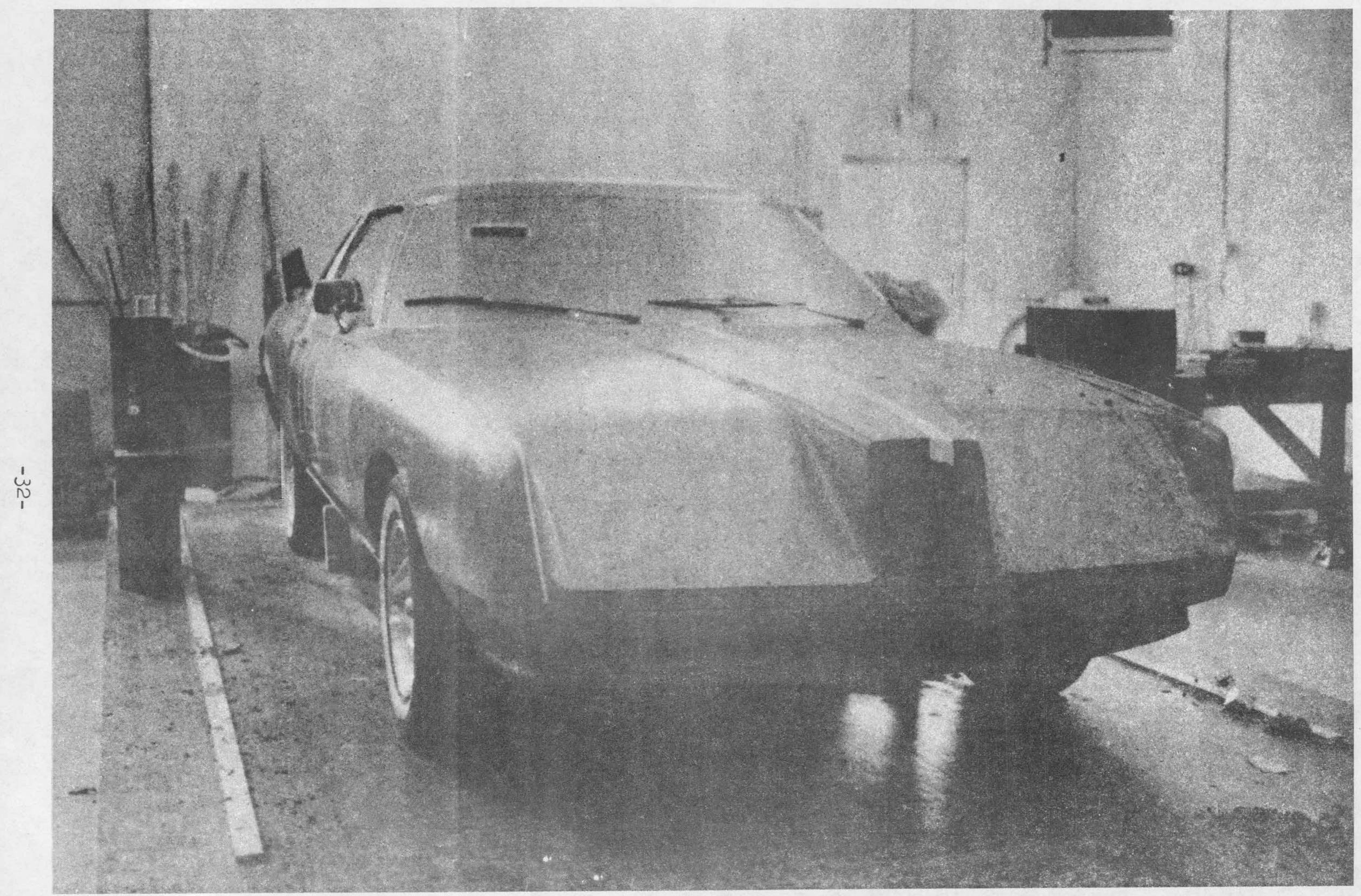

FIGURE 1

CLAY MODEL FOR PUBLIC INTEREST CAR 


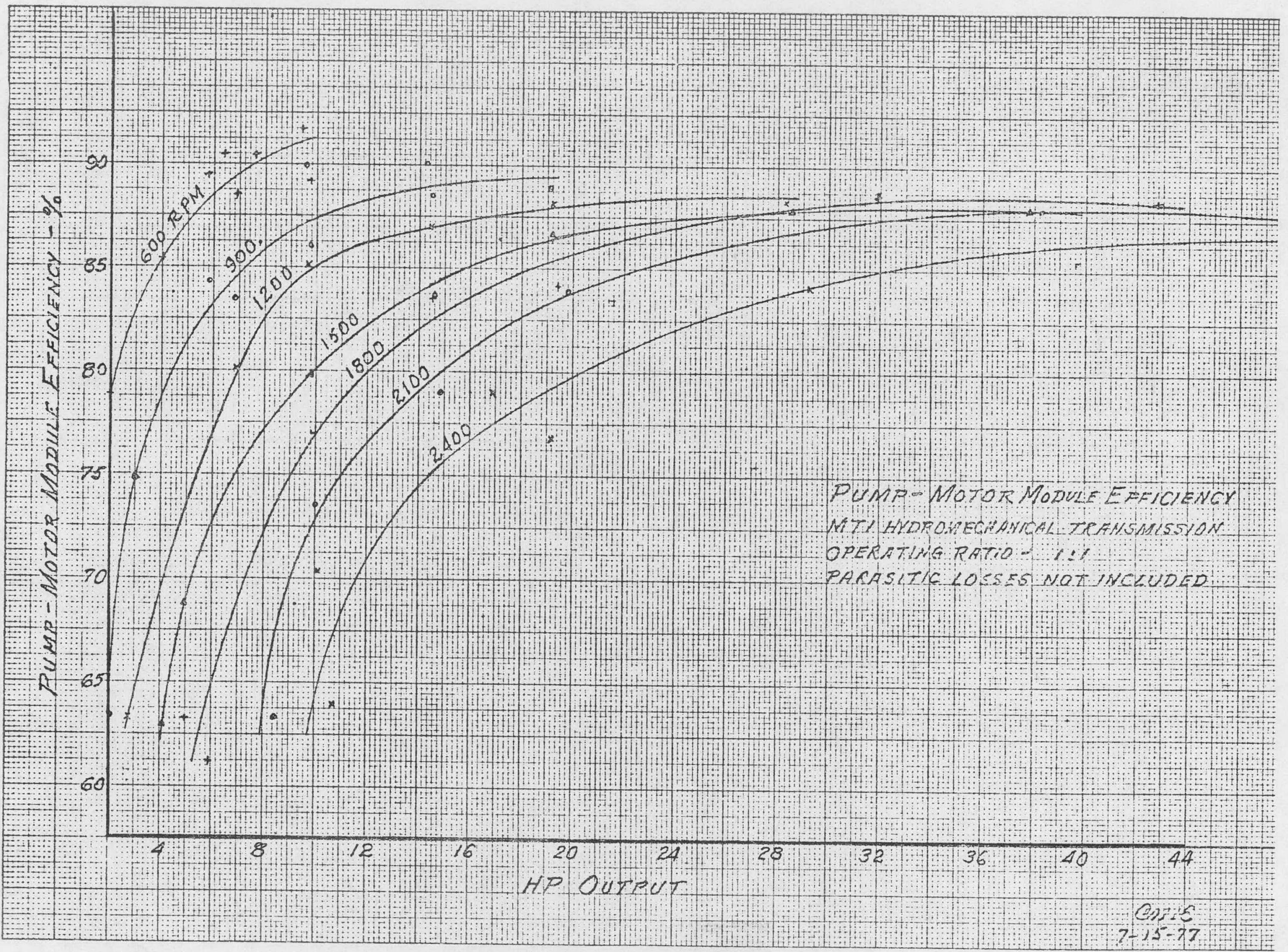


ENGINE STATUS

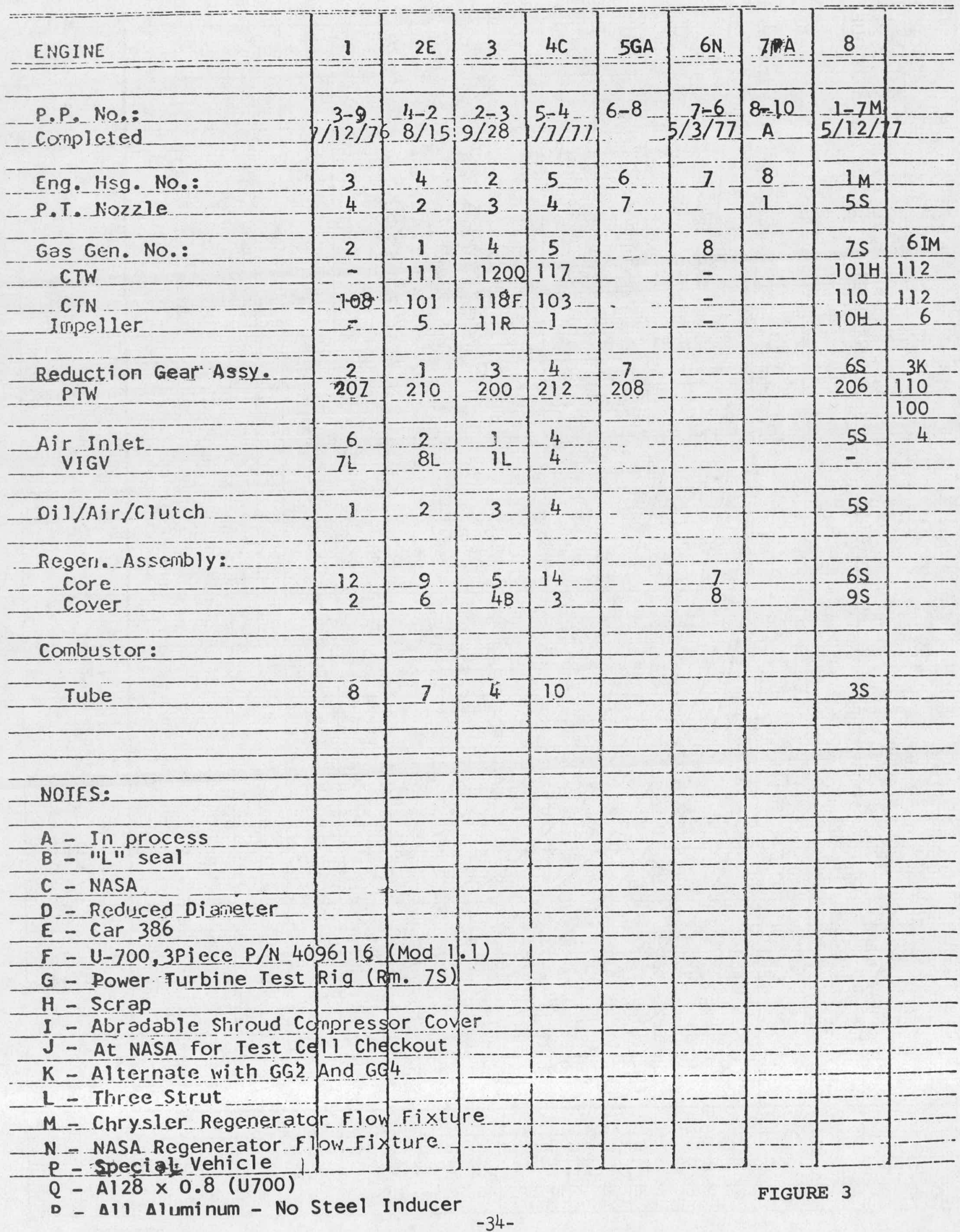


PART NAME

CTN Shroud - Outer Front

CTN Shroud - Outer Front (Steel)

CTN Shroud - Outer Rear

CTN Shroud - Quter Rear (Steel)

CTN - Mod 1 (Casting)

CTN - Mod 1.1 (Mach)

CTN - Mod 1.1 (Mach Steel)

CTN - Mod 2 (Mach)

CTN - Mod 2 (Mach Steel)

CTW - $128 \times 0.8$ (Mach)

CTW - $128 \times 0.8$ (Casting)

Impel ler-Splitter -

NASA $\times 0.8$

Ring - Deswirl Vane

Support - VIGV (Plastic)

Plate - Diffuser/Deswirl Assy 28 Channel, $+10,4^{\circ}$ Taper

Plate - Diffuser, 28 Vane Nominal

$+1^{\circ}$
$+2^{\circ}$
PART NO. QUANTITY

3814971

SK -21741

3814972

SK -21742

3814975

3814977

SK-21729

4096151

SK- 21730

3814966

3814996

4096125

3814958

3813883

SK-19988

四
4096120

4096121

4096122
4

2

4

4

2

3

3

1

1

2

2

1

1

6

2

2

20

2

(4)

\begin{tabular}{|c|c|}
\hline PROGRAM & DUE \\
\hline Component Development & Received \\
\hline NASA Cold Flow & Received \\
\hline Component Development & Received \\
\hline NASA Cold Flow & Received \\
\hline Component Development & Received \\
\hline Component Development & $8 / 3$ \\
\hline NASA Cold Flow & $8 / 11$ \\
\hline Component Development & $7 / 25$ \\
\hline NASA Cold Flow & $8 / 8$ \\
\hline Component Development & $8 / 12$ \\
\hline Component Development & $2-8 / 3, \quad 4-8 / 30$ \\
\hline Component Development & $8 / 15$ \\
\hline Component Development & Received \\
\hline Component Development & $B / P$ in process \\
\hline Component Development & $8 / 1$ \\
\hline $\begin{array}{ll}\text { NASA } & \text { Rig } \\
\text { NASA } & \text { Rig } \\
\text { NASA } & \text { Rig }\end{array}$ & $\begin{array}{l}7 / 18 \\
7 / 18 \\
7 / 18\end{array}$ \\
\hline
\end{tabular}

Component Development

Received

eived

Received

$8 / 3$

$8 / 11$

$2-8 / 3,4-8 / 30$

Component Development

$7 / 18$ 

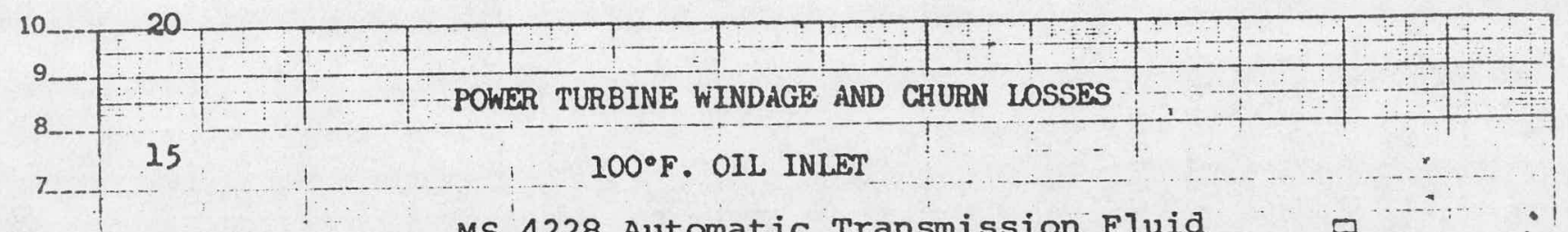

MS 4228 Automatic Transmission Fluid

PP $2-3 \mathrm{~V}-\mathrm{W}$

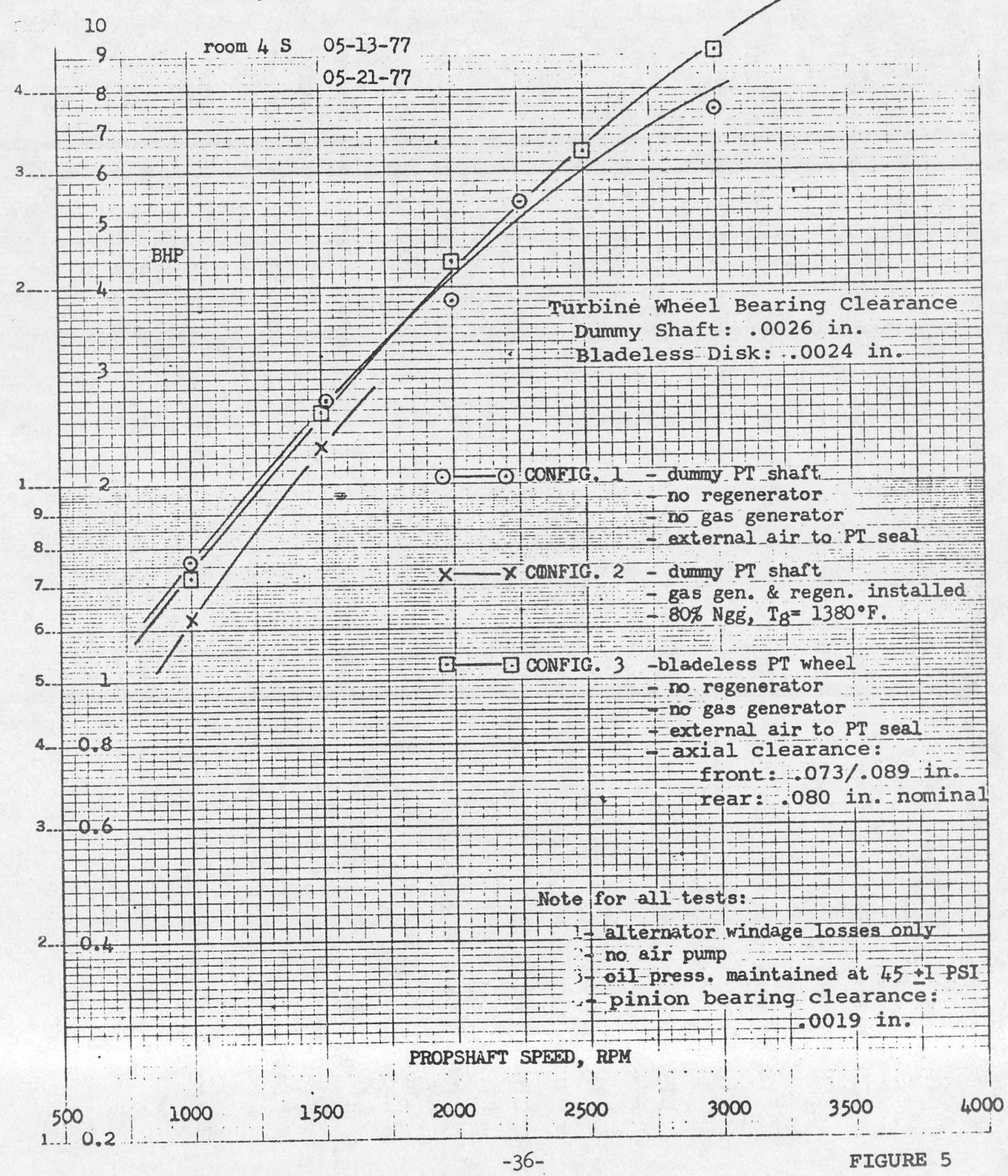



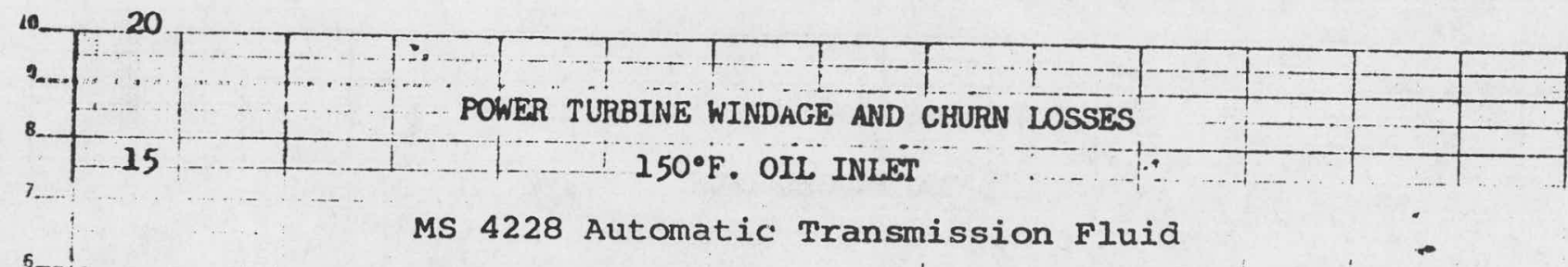

MS 4228 Automatic Transmission Fluid






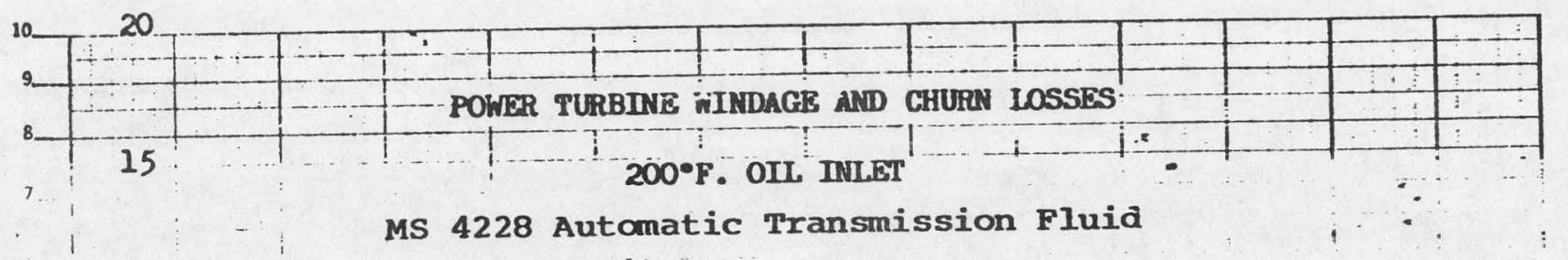

PP 2-3 V-id

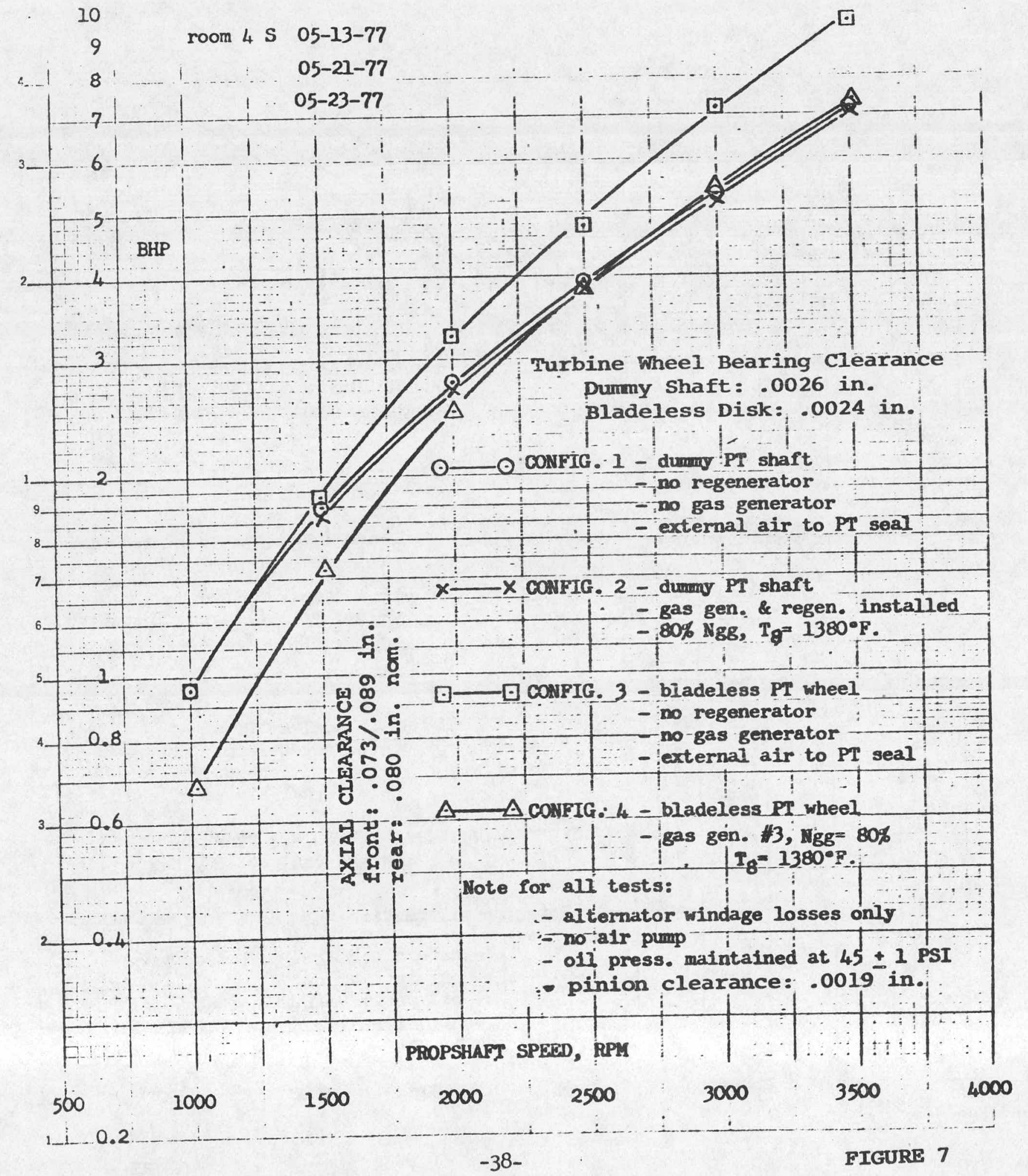




\begin{tabular}{|c|c|c|c|c|c|}
\hline $\begin{array}{l}\text { NASA } \\
\text { STATION }\end{array}$ & $\begin{array}{l}\text { TOTAL } \\
\mathrm{Nn} . \\
\end{array}$ & $\begin{array}{c}\mathrm{TCST} \\
\mathrm{A}\end{array}$ & $\begin{array}{c}\text { TEST } \\
B \\
\end{array}$ & $\begin{array}{c}\text { TEST } \\
\mathrm{C} \\
\end{array}$ & RTMARKS \\
\hline 0.0 & 2 & $A^{*}$ & $A$ & A & \\
\hline 0.5 & 2 & A & A & A & \\
\hline 1.0 & 2. & A & $A$ & A & \\
\hline 1.1 & 5 & 5 & A & A & Rake \\
\hline 1.5 & 4 & 4 & A & A & \\
\hline 1.9 & 4 & 4 & $A$ & A & \\
\hline 2.0 & 6 & 6 & A & A & \\
\hline 3.0 & 16 & $A$ & 16 & A & Grid \\
\hline 4.0 & 16 & A & 16 & A & Grid \\
\hline 5.2 & 2 & 2 & A & $A$ & Match Reference \\
\hline 6.0 & 3 & 3 & A & A & \\
\hline 6.0 & 3 & 3 & A & A & \\
\hline 6.3 & 3 & 3 & A & A & \\
\hline 6.3 & 3 & 3 & $A$ & A & \\
\hline 7.0 & 3 & 3 & A & A & \\
\hline 7.0 & 3 & 3 & A & A & \\
\hline 7.5 & 3 & 3 & A & A & Match Reference \\
\hline 8.0 & 16 & A & A & 16 & Grid \\
\hline 9.0 & 16 & A & A & 16 & Grid \\
\hline Exh. & 2 & 2 & 2 & 2 & \\
\hline$\overline{-}$ & 114 & 51 & & & \\
\hline
\end{tabular}

* Letter "A" designates thermocouples wired in parallel for average reading.

NASA

PAST
NO.
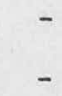

8-9

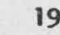

20-22

24-26

239-242

243-251

55-60

61-63

64-66

75-77

78-80

252-253

81-83

84-86

87-89

90-92

93-95

28-30

96-98

99-101

-

102-103
Filter Inlet

Filter outlet

VIGV Inlet

VIGV nut let Total

Diffuser Mid-Channel Total

Deswirl Outlet Total

Compressor Collector Outlet Total

Regenerator Inlet (Air Side)

Regenerator Outlet (Air Side)

CT Nozzle Inlet Total

CT Wheel outlet Total

CT Wheel outlet Outer Sisroud Wall

Pr Nozzle Inlet Total

PT Nozzle Inlet Outer Shroud Wall

PT Wheel Outlet rotal

PT Nozzle Outlet Outer Shroud Wall

PT Exhaust Diffuser outlet

Regenerator Inlet (Gas Side)

Regenerator Outlet (Gas Side)

Regenerator Cover Exhaust $\mathrm{Fl}$ ange

TOTAL.

\begin{tabular}{|c|c|c|c|c|}
\hline $\begin{array}{l}\text { STATION } \\
\text { NO. } \\
\end{array}$ & $\begin{array}{c}\text { TEST } \\
\text { A }\end{array}$ & $\begin{array}{l}\text { TEST } \\
B \\
\end{array}$ & $\begin{array}{l}\text { TEST } \\
\mathrm{C} \\
\end{array}$ & REMARKS \\
\hline - & 1 & 1 & 1 & $\begin{array}{l}\text { Test cell Instru- } \\
\text { mentation. }\end{array}$ \\
\hline - & 1 & 1 & 1 & $\begin{array}{l}\text { Test cell Instru- } \\
\text { mentation. }\end{array}$ \\
\hline 0.0 & 2 & 2 & 2 & $\begin{array}{l}\text { Port No's supplied } \\
\text { by Chrysler. }\end{array}$ \\
\hline 0.5 & 1 & 1 & 1 & \\
\hline 1.0 & 3 & $A^{*}$ & A & \\
\hline 1.0 & 3 & A & A & \\
\hline 1.1 & 4 & A & A & \\
\hline 1.9 & A & 9 & A & \\
\hline 2.0 & A & 6 & A & \\
\hline 3.0 & A & A & 3 & Grid \\
\hline 4.0 & A & A & 3 & Grid \\
\hline 5.2 & 3 & A & A & \\
\hline 5.2 & 3 & A & A & \\
\hline 5.3 & 2 & A & A & \\
\hline 6.0 & 3 & A & A & \\
\hline 6.0 & 3 & A & A & \\
\hline 6.3 & A & A & 3 & \\
\hline 6.3 & A & A & 3 & \\
\hline 7.0 & A & A & 3 & \\
\hline 7.0 & A & A & 3 & \\
\hline 8.0 & A & 3 & 3 & Grid \\
\hline 9.0 & A & 3 & 3 & Grid \\
\hline - & 1 & 1 & 1 & $\begin{array}{l}\text { Test Cell Instru- } \\
\text { mentation. }\end{array}$ \\
\hline
\end{tabular}

* Letter "A" designates pressure linns connected ill parallel for average reading. 
BSFC VS. OUTPUT HORSEPOWER

PP $5-4$

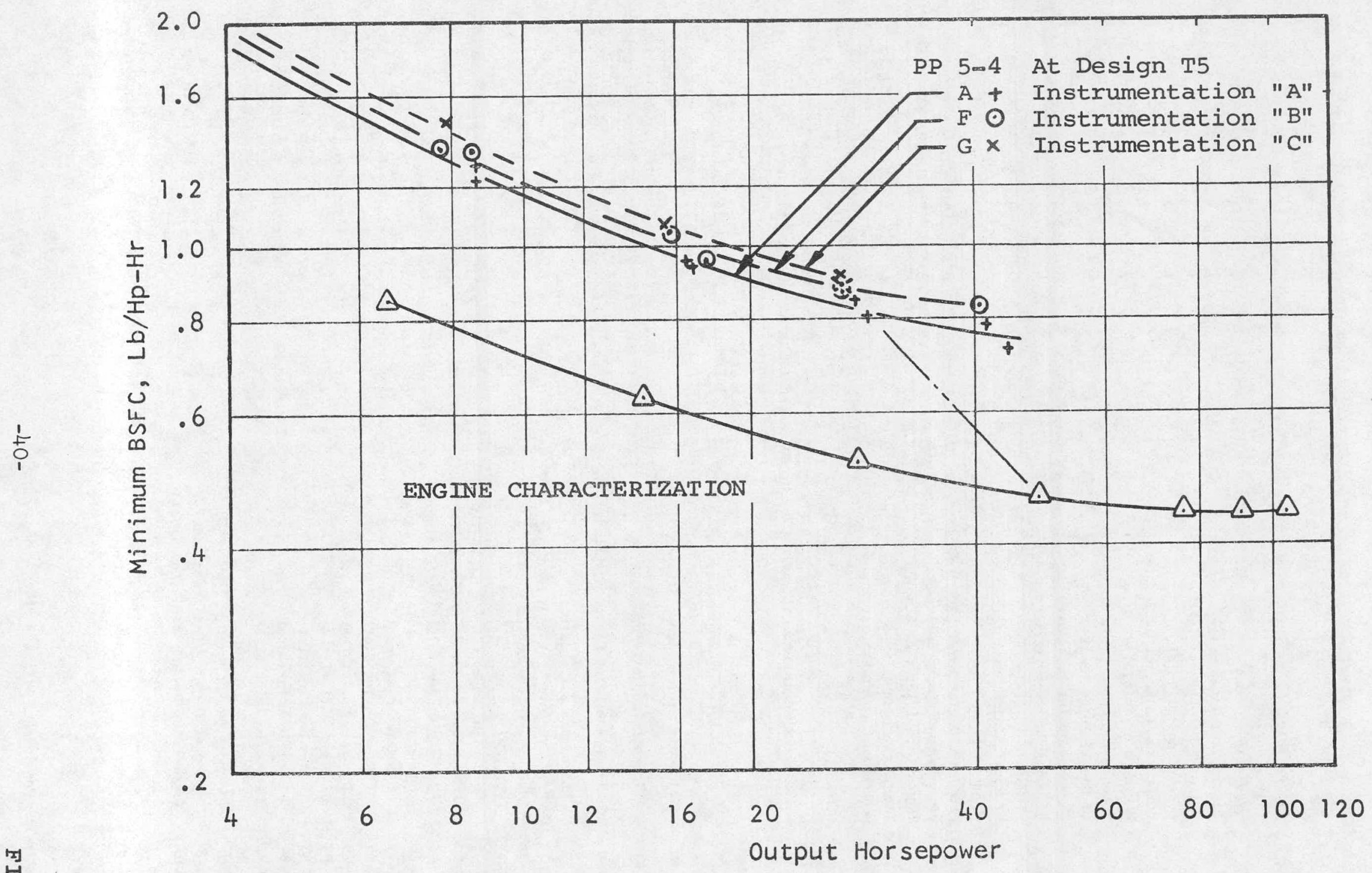

国 

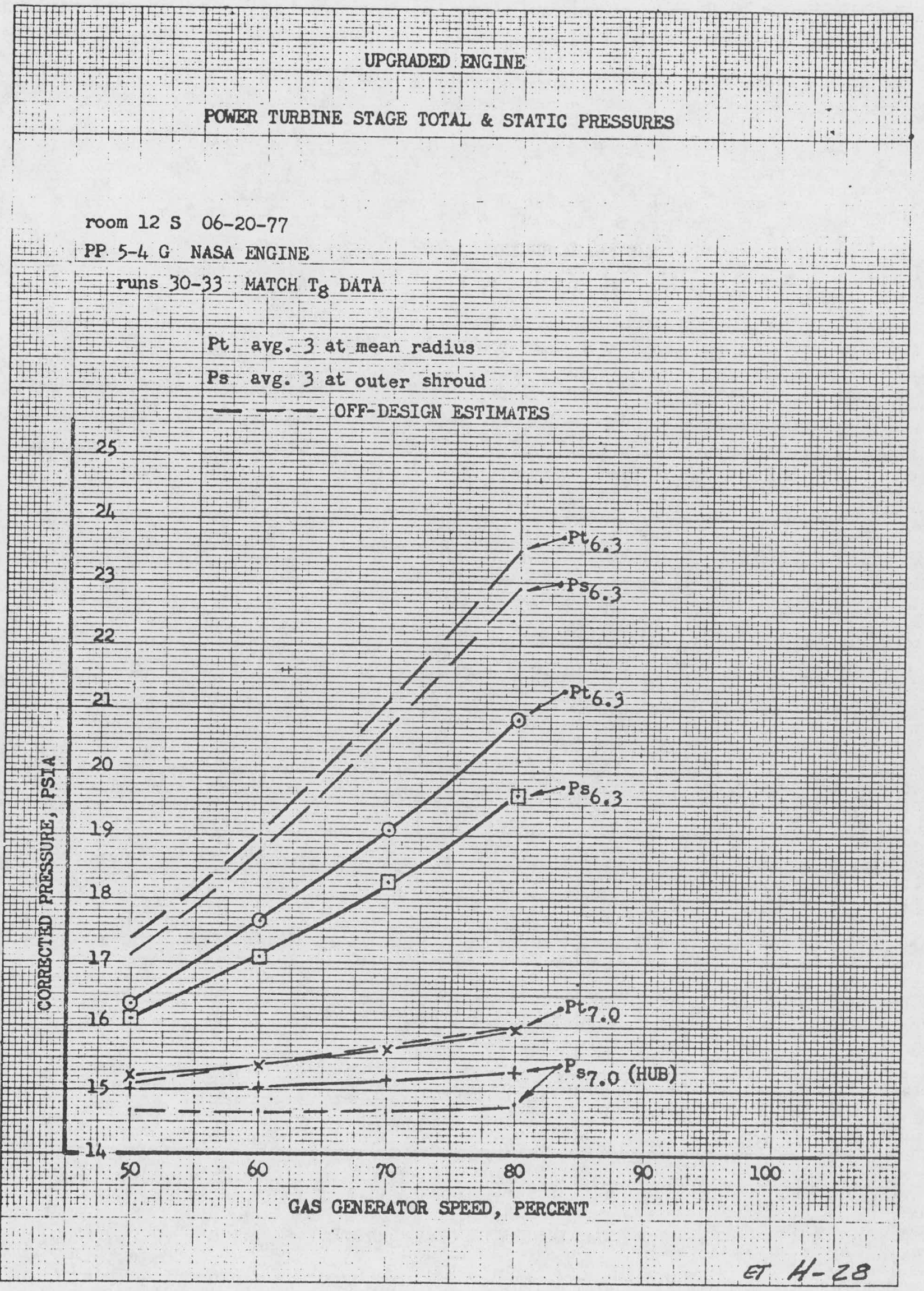

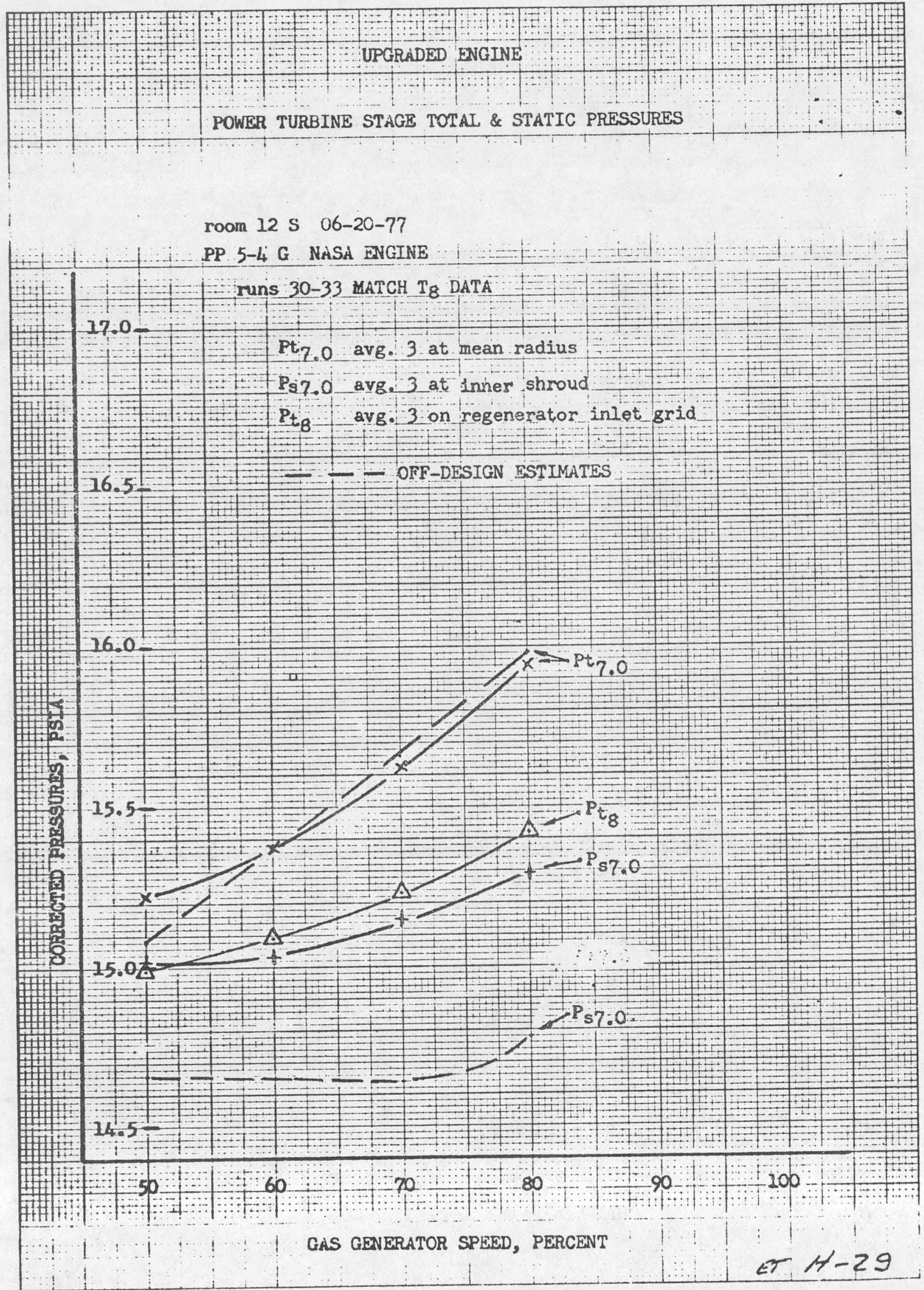
HIGH PRESSURE SIDE

RHGENERATOR OUTLET GRID STATION
LOW PRESSURE STDE

REGENIERATOR INLET GRID STLITION 8

$50 \% \mathrm{Ngg}$

.00ㅍ 12 s 06-14-77

गP 5-4 F Jur: 22 match $T_{8}$

NASA instrumentation " $B$ "

$\stackrel{t}{\ddagger}$

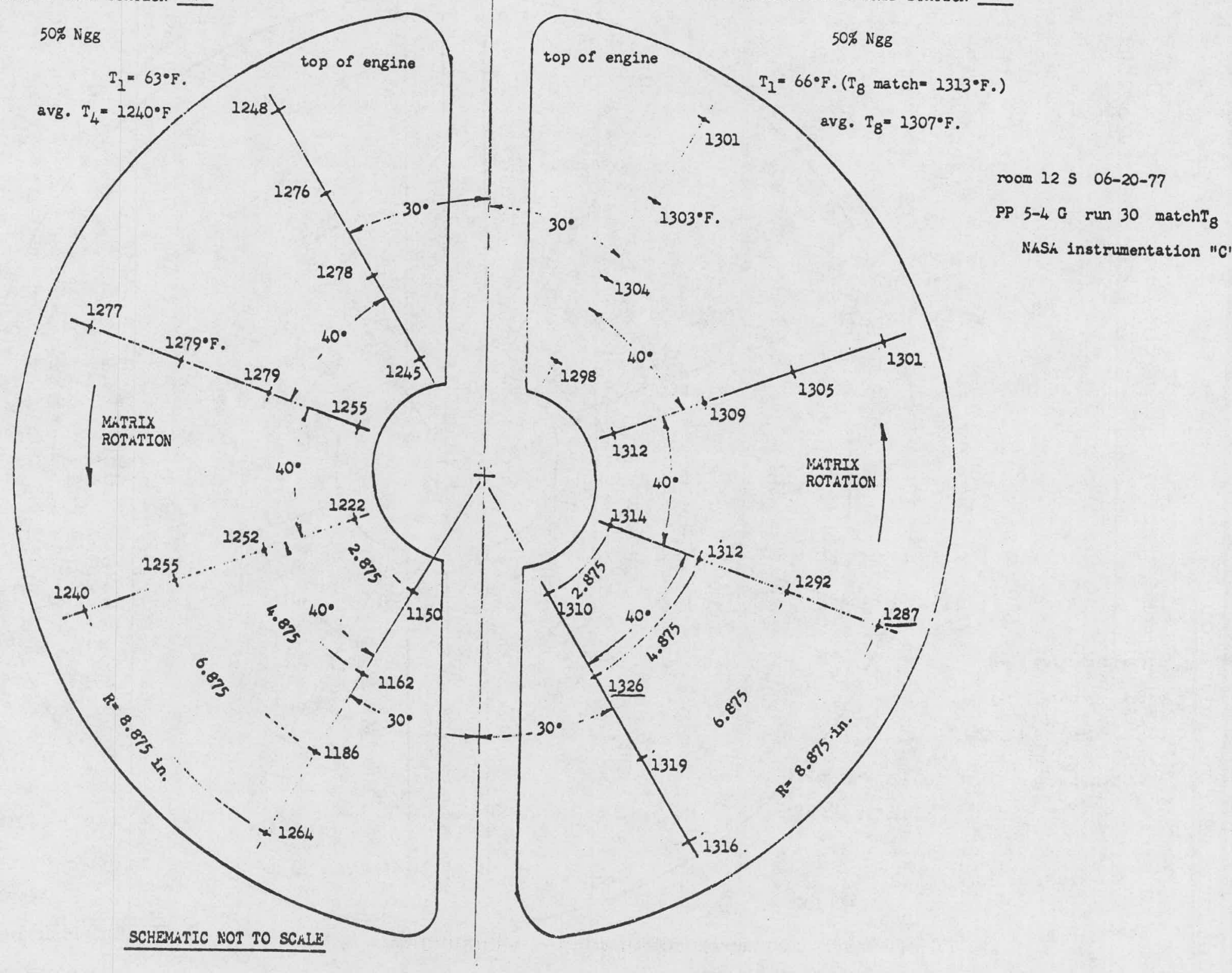


LOW PRESSURE SIDE

REGENERATOR OUTLET GRID STATION 9

room 12 s 06-20-77

PP 5-4 G $\min 30$ match $\mathrm{T}_{8}$ NÁSÁ instrumentation "C"

\section{HIGH PRESSURE SIDE}

REGERERRATOR INLET GRID STATION 3

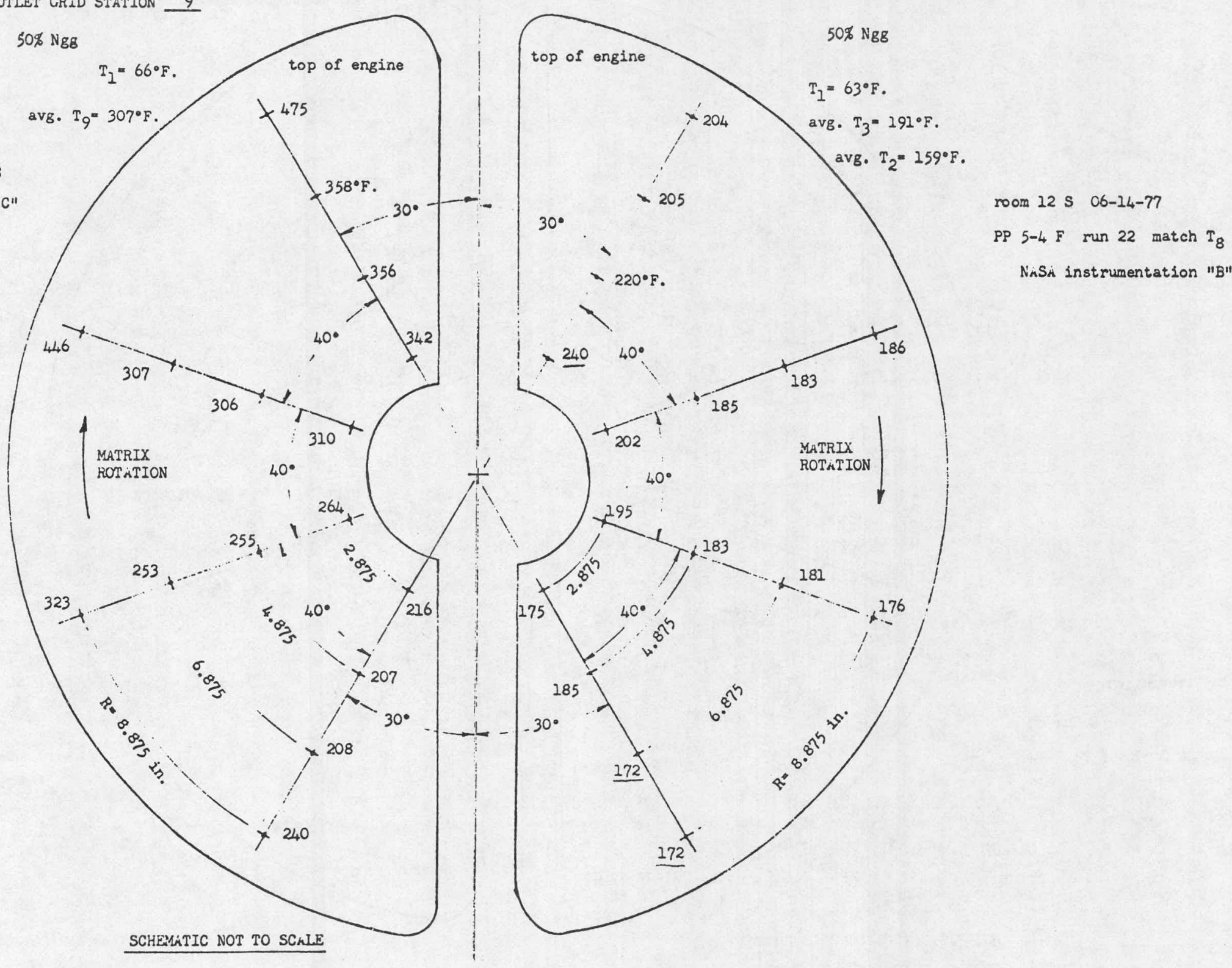


BSFC VS. OUTPUT HORSEPOWER

PP 2-3
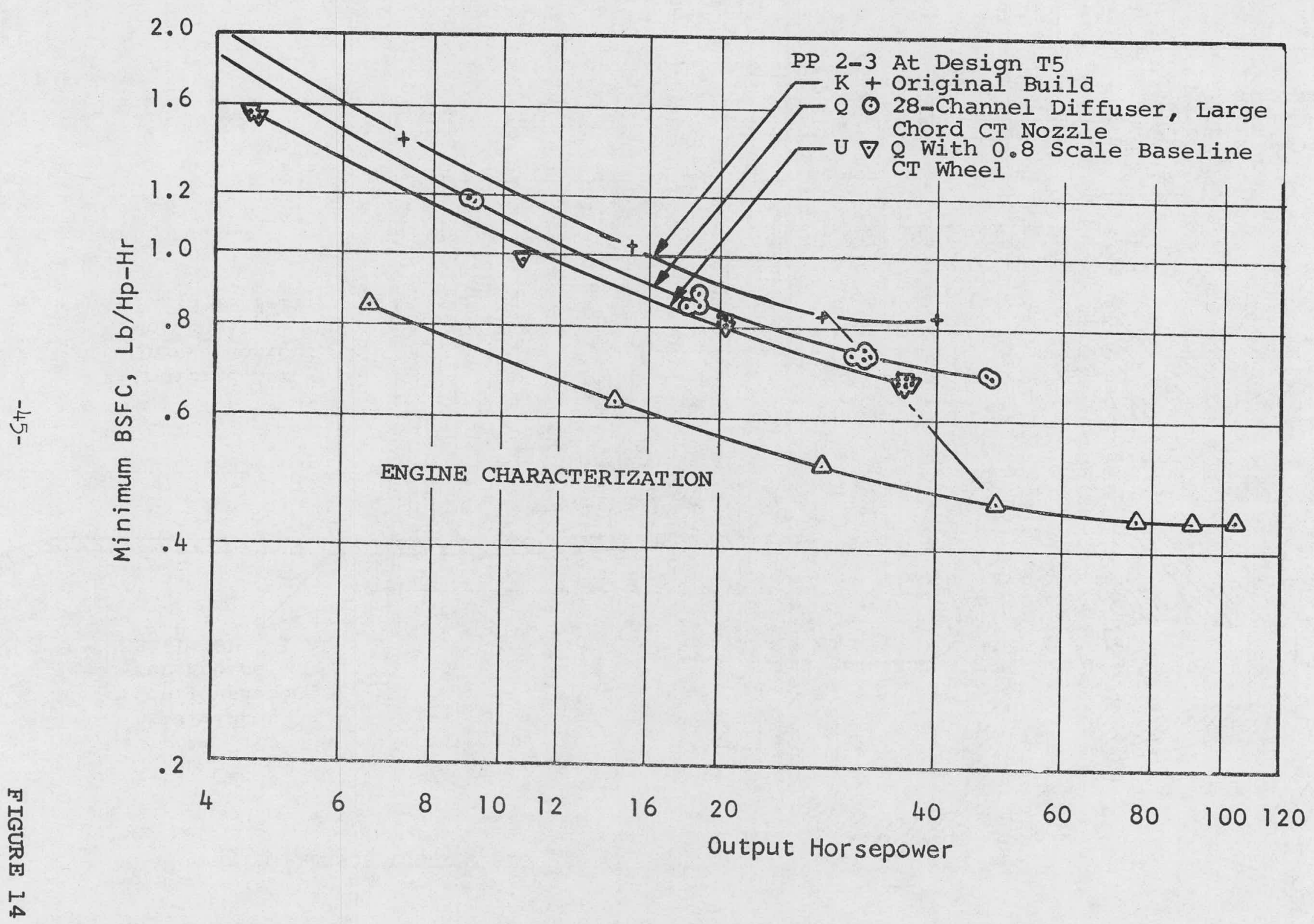
COMPRESSOR INLET TESTS

Axial Inlet

Configuration

For Engine

8

Build PP 3-1 AI

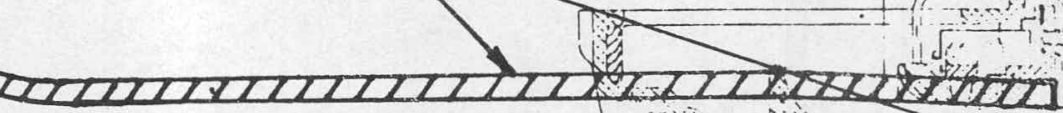

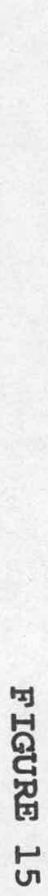

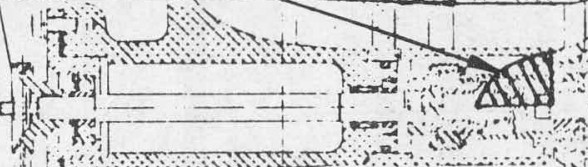

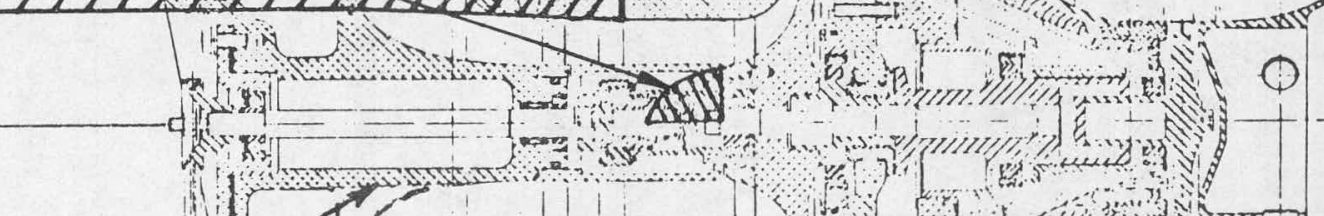

$c_{\Gamma}$

$>$

Modified Air

Intake Contour

For Engine

Build PP 2-3Y

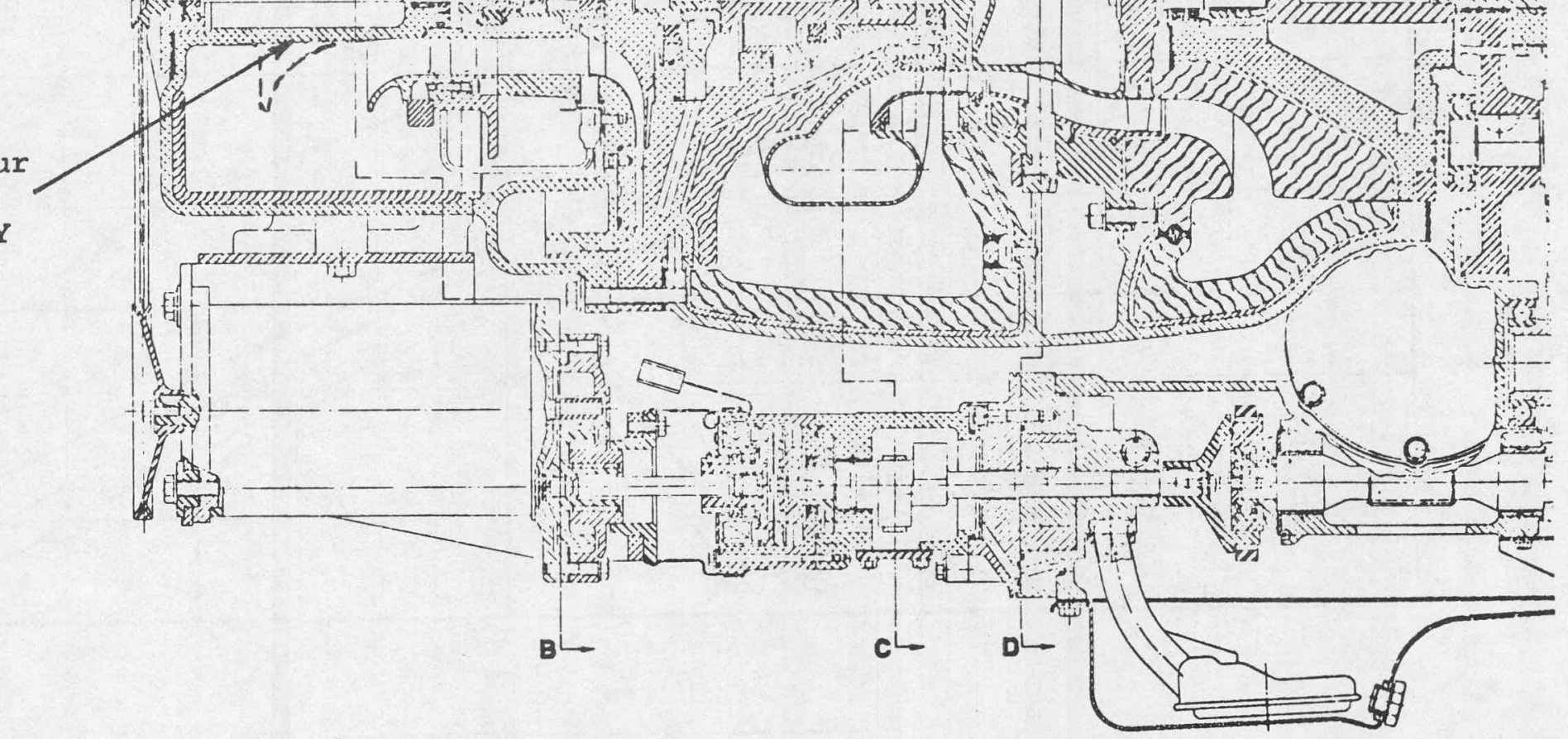




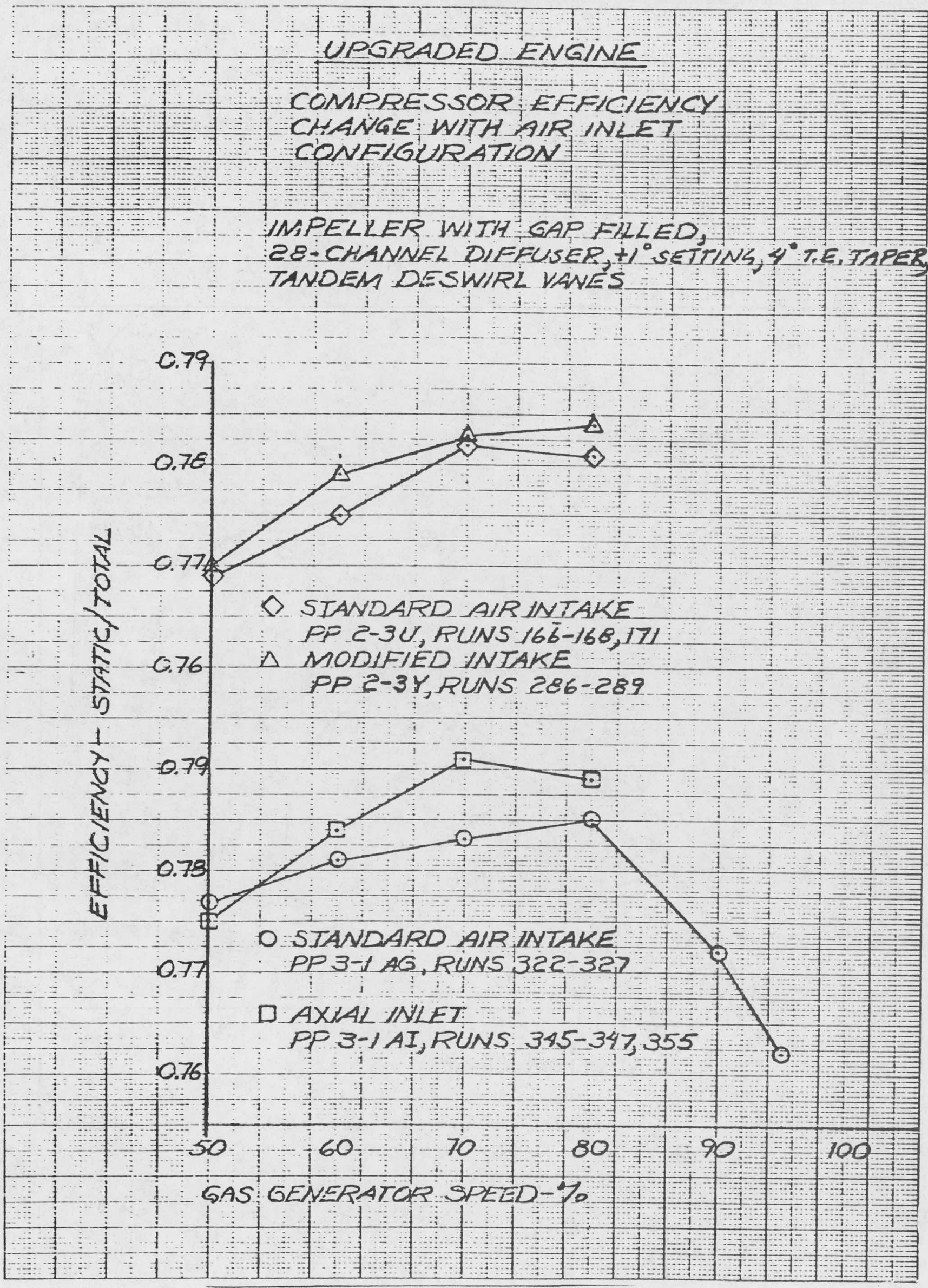




\section{UPGRADED ENGINE}

- RIG DATA 14 channel, $+1^{\circ}$ diffuser

$\odot$ STD. DIFFUSER $\left(14\right.$ channel, $\left.+1^{\circ}\right)$ NON-SURGE DATA

$\diamond \quad 28$ channel, $+1^{\circ}$ diffuser

SURGE DATA

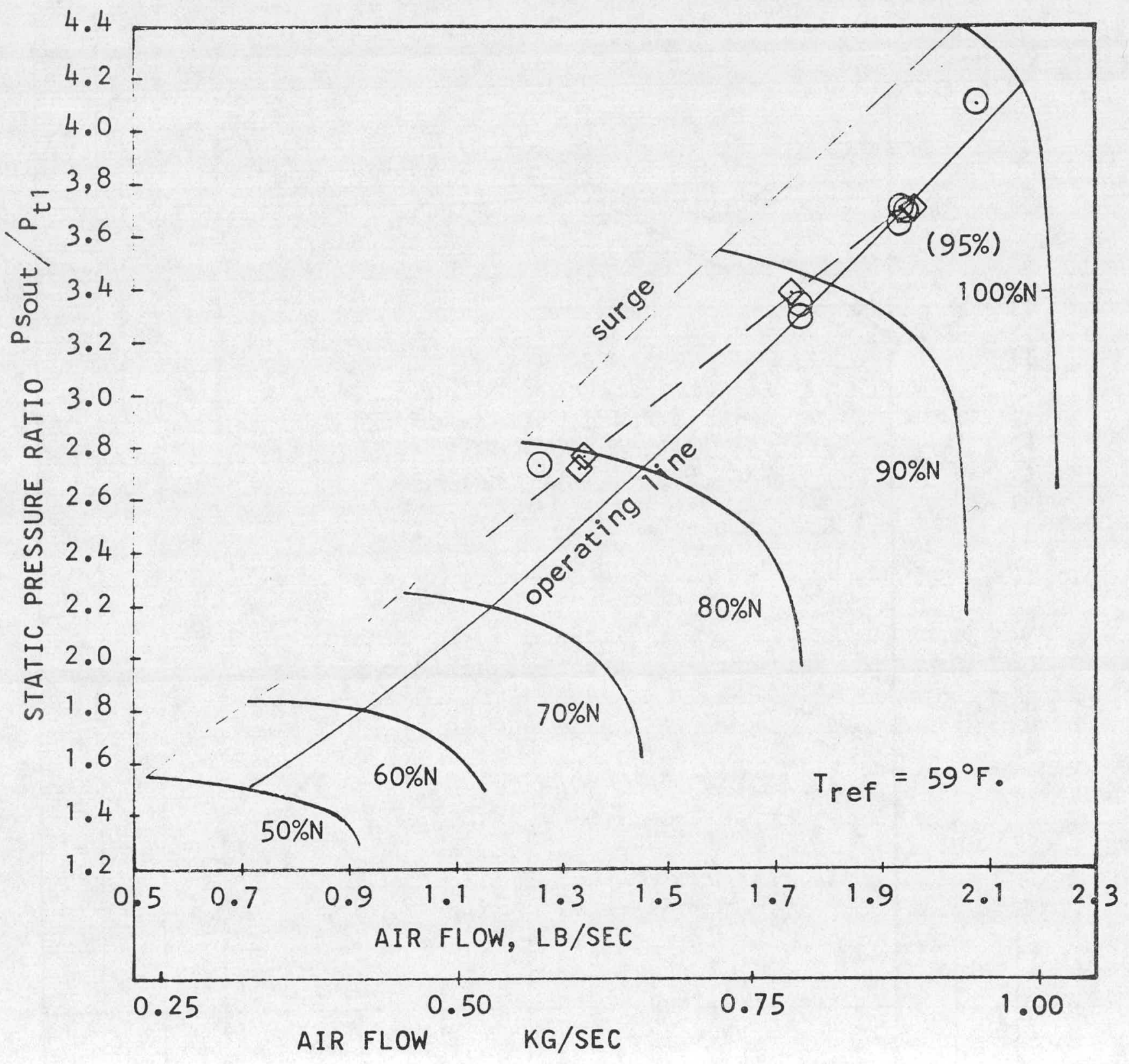




\section{UPGRADED ENGINE COMPRESSOR}

\section{a. CASCADE DIFFUSER DESIGN}

VARIATION OF MACH NUMBER, FLOW ANGLE AND DIFFUSION FACTOR ALONG FLOWPATH

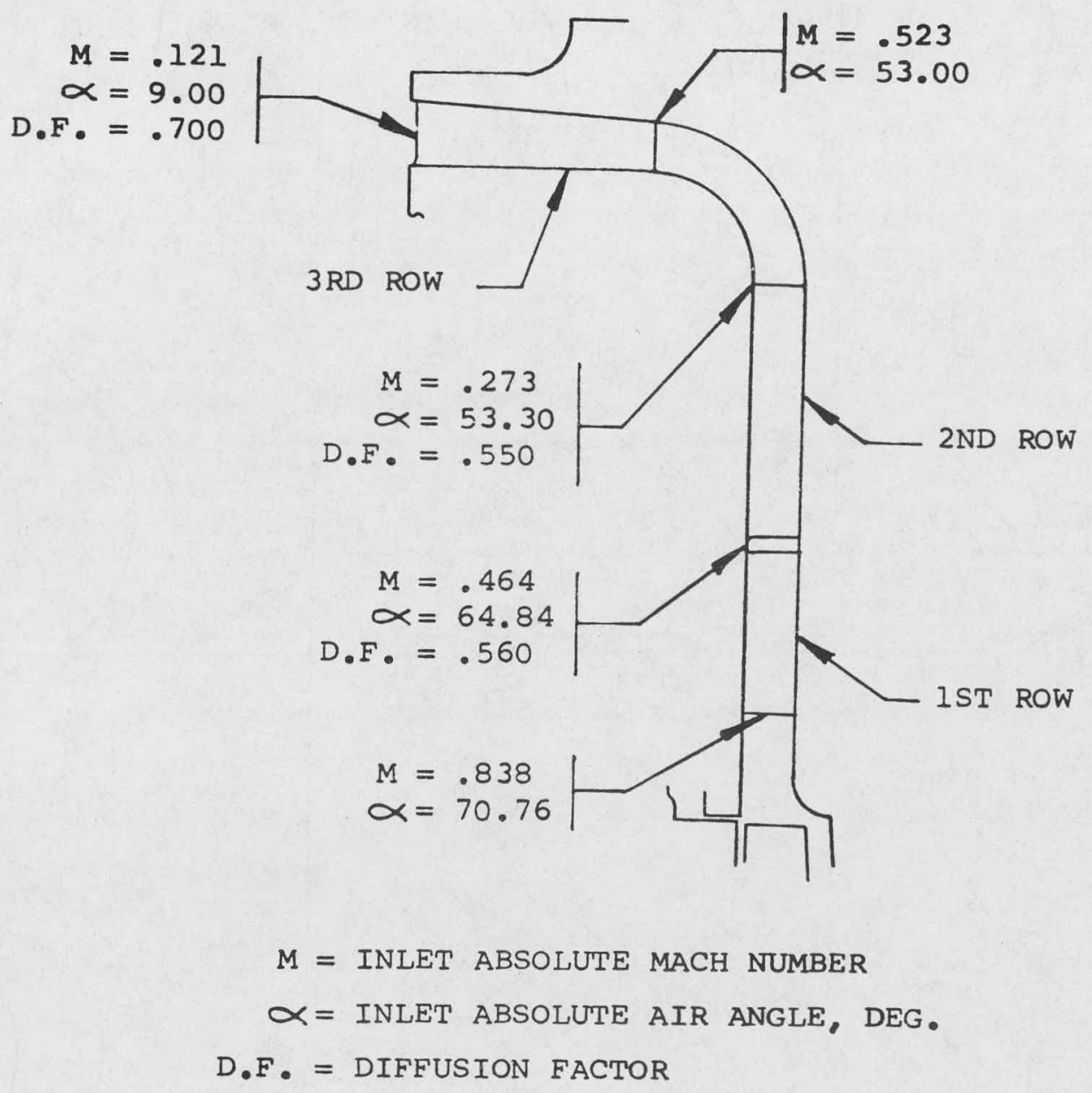

\section{b. FRONT VIEW OF RADIAL DIFFUSER}

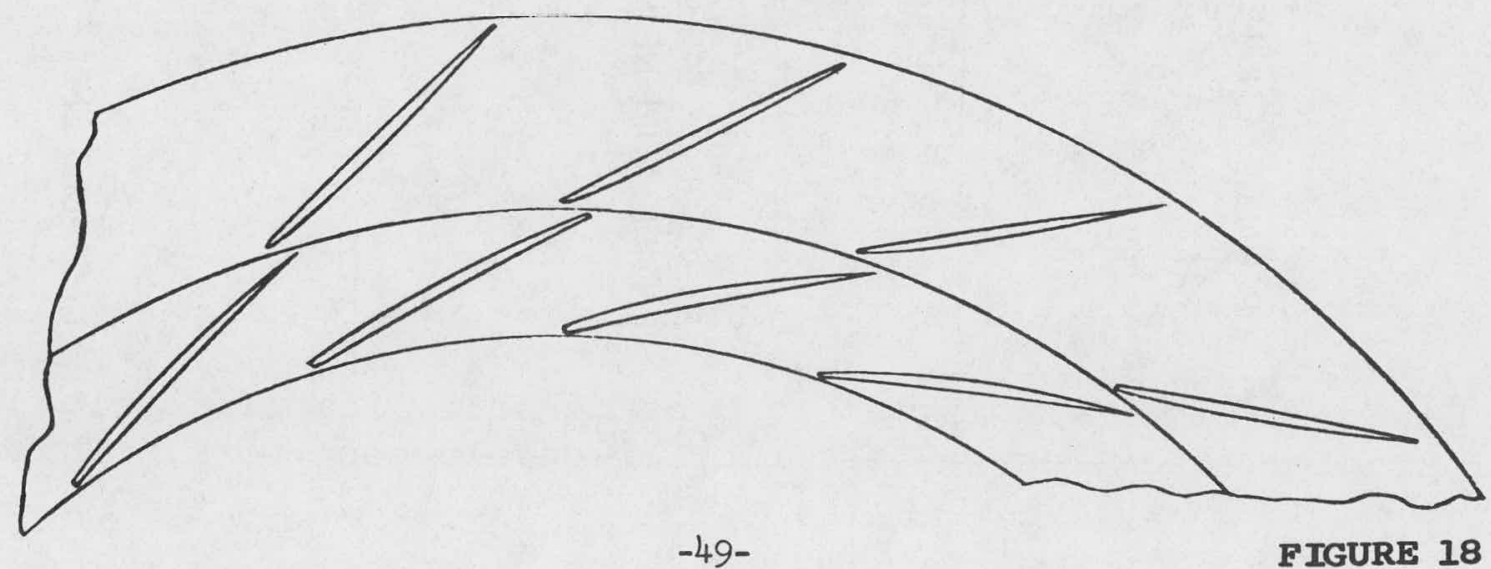




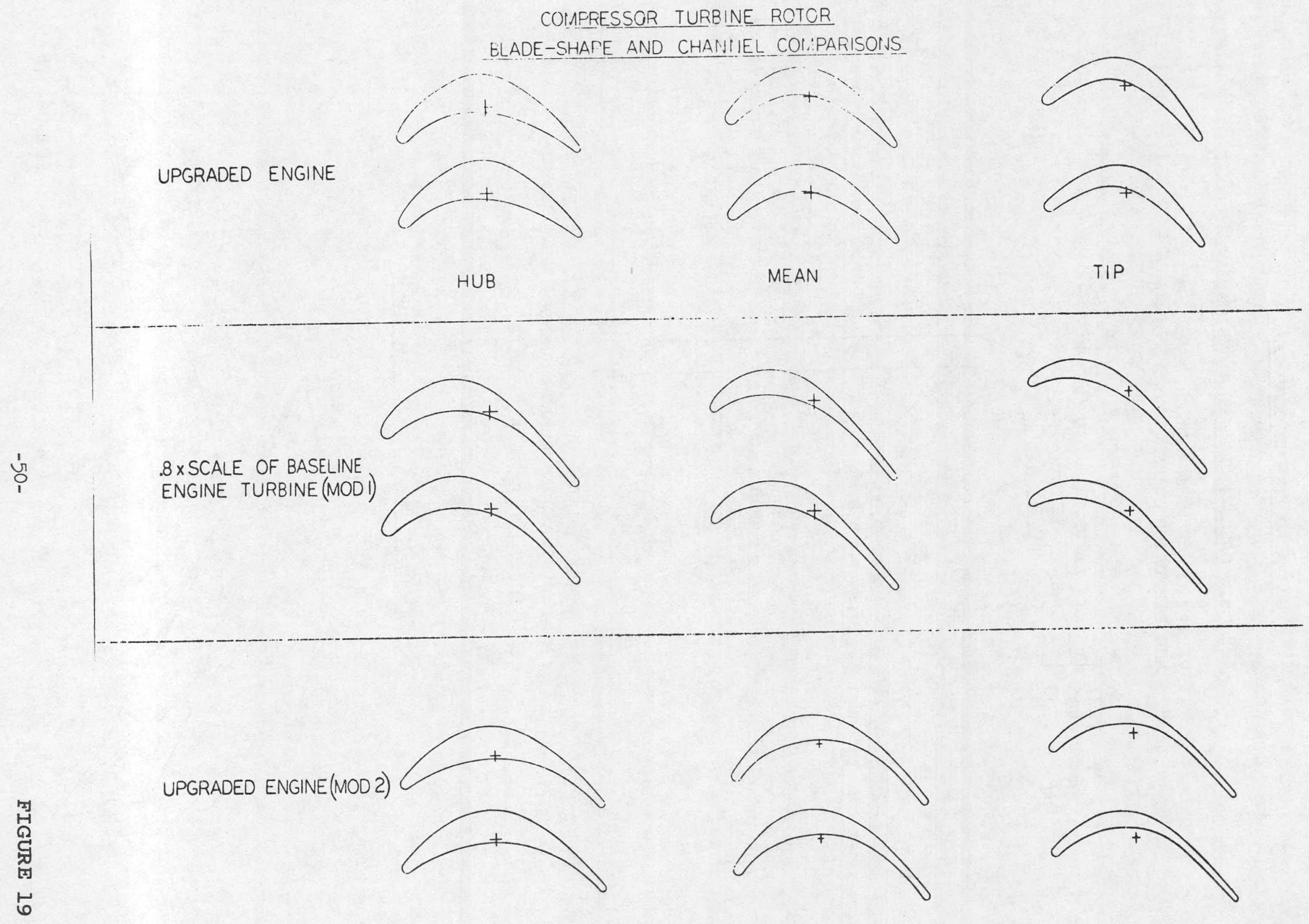




\section{UPGRADED ENGINE}

Compressor Turbine Redesign

100\% Speed Rotor Characterization

\begin{tabular}{|c|c|c|c|}
\hline Radius, in & 1.75 & 1.97 & 2.19 \\
\hline Pitch, in & .17735 & .19964 & .22194 \\
\hline Chord, in & .4278 & .4141 & .4013 \\
\hline Axial Chord, in & .4244 & .4097 & . 3880 \\
\hline Solidity & 2.412 & 2.074 & 1.808 \\
\hline Axial Solidity & 2.393 & 2.052 & 1.748 \\
\hline Stagger Angle (rel. to axial) & $6.4^{\circ}$ & $8.7^{\circ}$ & $15.0^{\circ}$ \\
\hline Inlet Blade Angle (rel. to axial) & $41.0^{\circ}$ & $54.0^{\circ}$ & $40.0^{\circ}$ \\
\hline Incidence Angle & $-1.0^{\circ}$ & $-4.2^{\circ}$ & $-4.8^{\circ}$ \\
\hline Exit Blade Angle (rel. to axial) & $51.0^{\circ}$ & $50.8^{\circ}$ & $50.3^{\circ}$ \\
\hline Deviation Angle & $6.3^{\circ}$ & $7.7^{\circ}$ & $6.8^{\circ}$ \\
\hline Camber Angle & $92.0^{\circ}$ & $104.8^{\circ}$ & $90.3^{\circ}$ \\
\hline Deflection Angle (rel. to moving blade) & $84.7^{\circ}$ & $92.0^{\circ}$ & $78.7^{\circ}$ \\
\hline Leading Edge Radius, in & .0110 & .0110 & .0100 \\
\hline Trailing Edge Radius, in & .0080 & .0078 & .0060 \\
\hline Maximum Blade Thickness, in & .0674 & .0521 & .0359 \\
\hline Profile Crossectional Area, in ${ }^{2}$ & .0205 & .0157 & .0106 \\
\hline Throat, in & .1077 & .1166 & .1377 \\
\hline Reaction, Enthalpy-Based & -.141 & .131 & .129 \\
\hline Reaction, Static-Pressure-Based & .032 & .126 & .210 \\
\hline Zweifel Loading coefficient & .772 & 1.118 & .996 \\
\hline Unguided Turn & $12.0^{\circ}$ & $11.9^{\circ}$ & $7.7^{\circ}$ \\
\hline Suction Surface Diffusion Parameter, $D_{p}$ & .143 & .165 & .107 \\
\hline Suction Surface Diffusion Parameter, $D_{r}$ & .193 & .290 & .401 \\
\hline Pressure Surface Diffusion Parameter, $\frac{1}{D_{p}}$ & .168 & .125 & .190 \\
\hline Pressure Surface Diffusion Parameter, $D_{r}$ & - 404 & .271 & .498 \\
\hline Enthalpy Drop, Btu/Lbm & -83.0 & $-90 \cdot 6$ & -73.0 \\
\hline Flow Coefficient, $V_{x} / U$ & & 1.07 & \\
\hline Specific Speed & & 86.0 & \\
\hline Blade - Jet Speed Ratio U/V nte & & .433 & \\
\hline $\begin{array}{l}\text { Aspect Ratio } \\
\text { Blade Number }\end{array}$ & & 1.074 & \\
\hline & & 62 & \\
\hline $\begin{array}{l}\text { Taper Ratio } \\
\text { Blade Height, in }\end{array}$ & & $\begin{array}{c}1.934 \\
.44\end{array}$ & \\
\hline Radius Ratio & & 0.84 & \\
\hline Blade Inertia, in-lbf-sec ${ }^{2}$ & & .0000206 & \\
\hline Tip Clearance, in & & .008 & \\
\hline
\end{tabular}

Diffusion Parameters

$\mathrm{D}_{\mathrm{p}}=\frac{\mathrm{M}_{\max }-\mathrm{M}_{\min }}{\mathrm{M}_{\max }}$

$$
\begin{aligned}
M_{\max }= & \text { Maximum Surface Mach Number } \\
M_{\text {min }}= & \text { Minimum Surface Mach Number } \\
s= & \text { Distance along blade surface over } \\
& \text { which diffusion occurs }
\end{aligned}
$$$$
\text { s = Distance along blade surface over }
$$$$
\text { which diffusion occurs }
$$$$
D_{r}=\frac{\frac{M_{\max }-M_{\min }}{M_{\min }}}{\frac{s}{S_{\text {tot }}}}
$$ 


\section{UPGRADED ENGINE}

COMPRESSOR TURBINE REDESIGN

100\% SPEED VECTOR DIAGRAM

TIP

$r=5.563 \mathrm{~cm}$

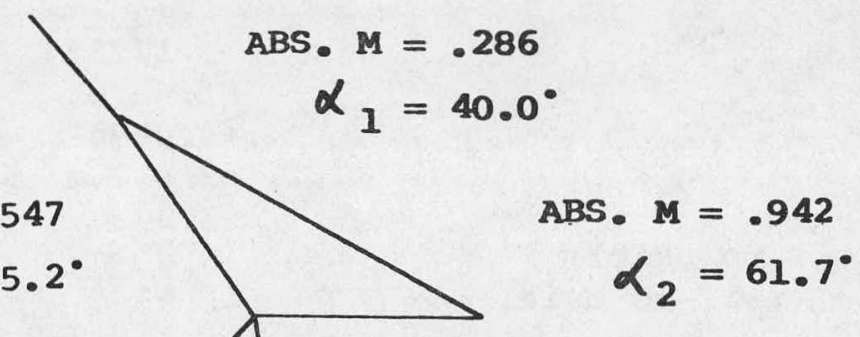

$$
\text { REL. } \begin{aligned}
M & =.636 \\
\beta_{3} & =-43.6^{\circ}
\end{aligned}
$$

ABS. $M=.468$

$\alpha_{3}=9.8^{\circ}$

$$
U=340.8 \mathrm{~m} / \mathrm{sec}
$$

MEAN

$r=5.041 \mathrm{~cm}$

$$
\text { ABS. } M=.355
$$

REL. $M=.691$

$$
\alpha_{1}=49.1^{\circ}
$$

$$
\beta_{2}=49.8^{\circ}
$$

REL. $M=.787$

$$
\beta_{3}=-42.2^{\circ}
$$

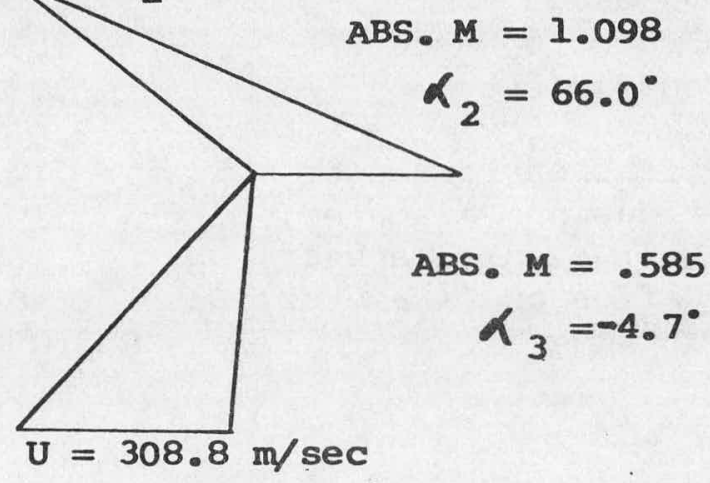

HUB

$r=4.445 \mathrm{~cm}$

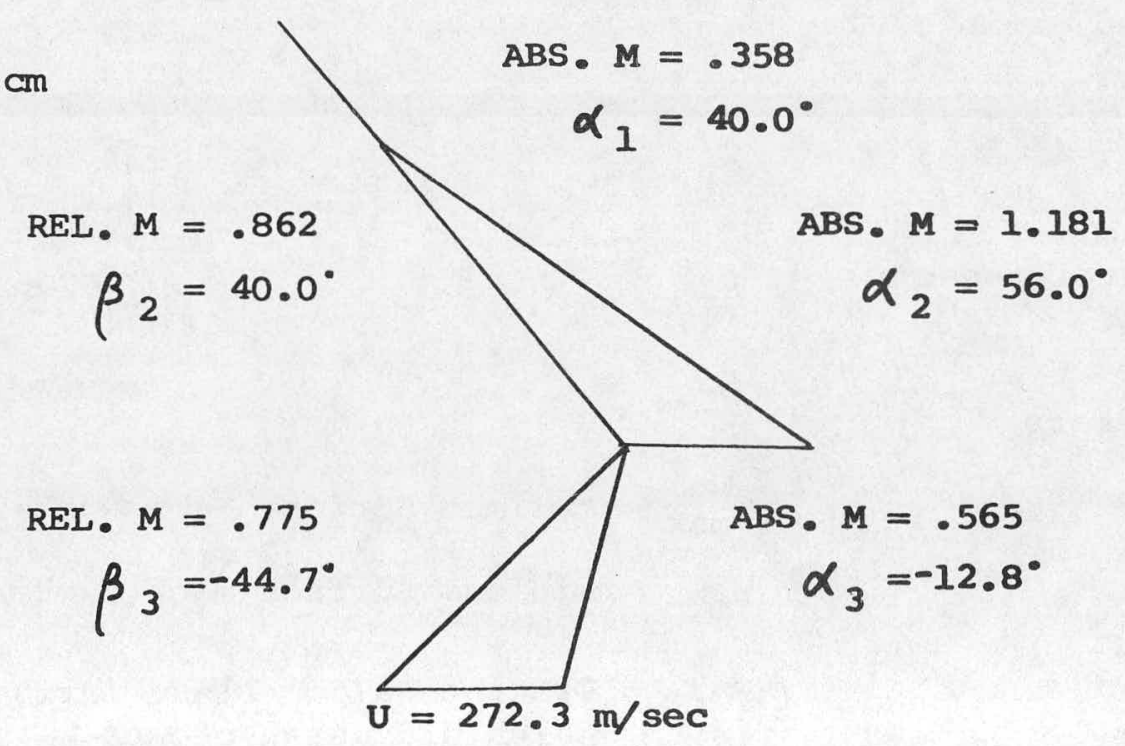

FIGURE 21 


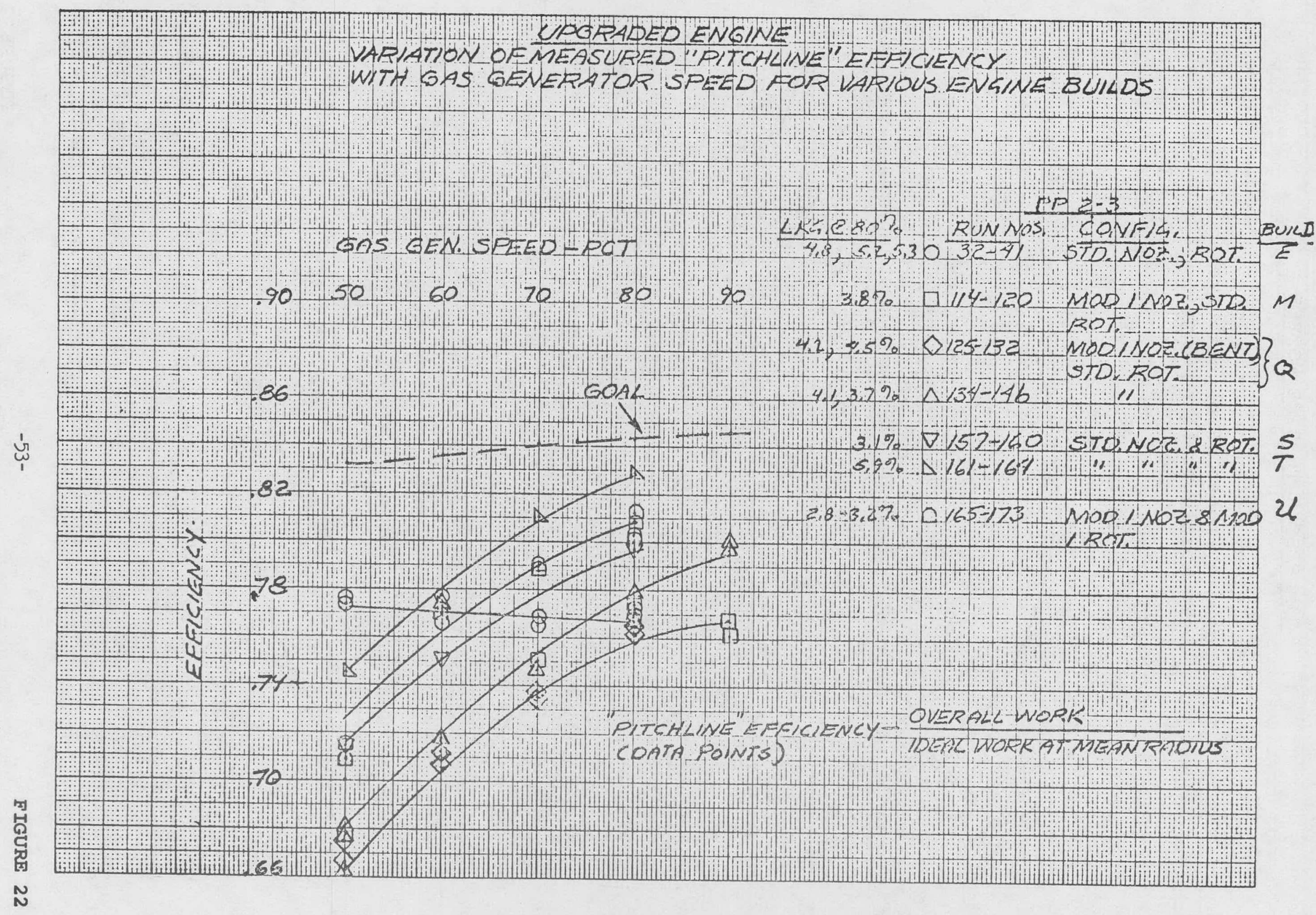




\section{UPGRADED ENGINE}

\section{COMPRESSOR TURBINE NOZZLE}

Positions of Rotor Exit Total Pressure Probes (PT6) Relative To Nozzle Trailing Edge

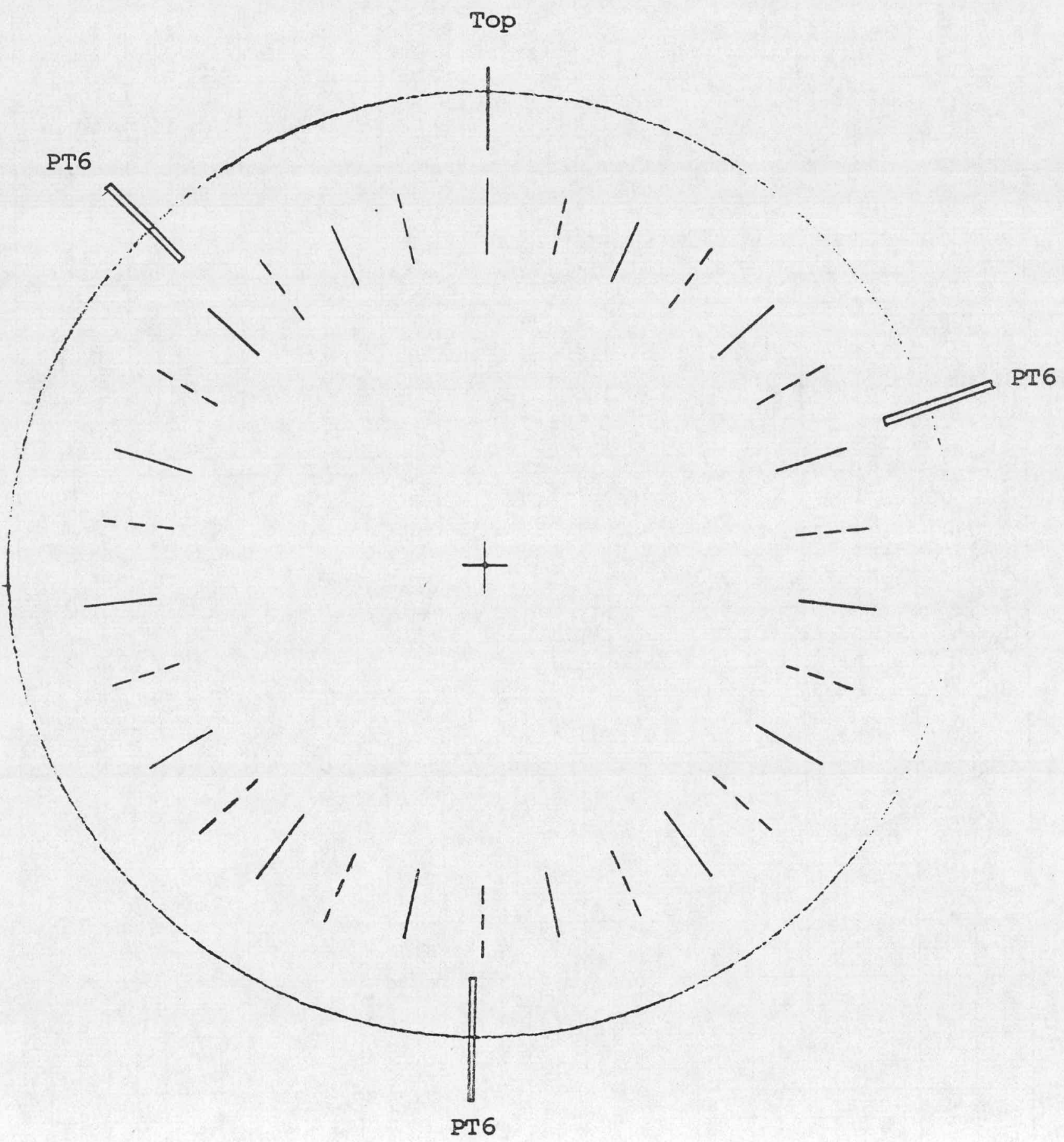

- Standard $S / N 108$

$\ldots$ Mod 1 (Bent) $\mathrm{S} / \mathrm{N} 117$ 


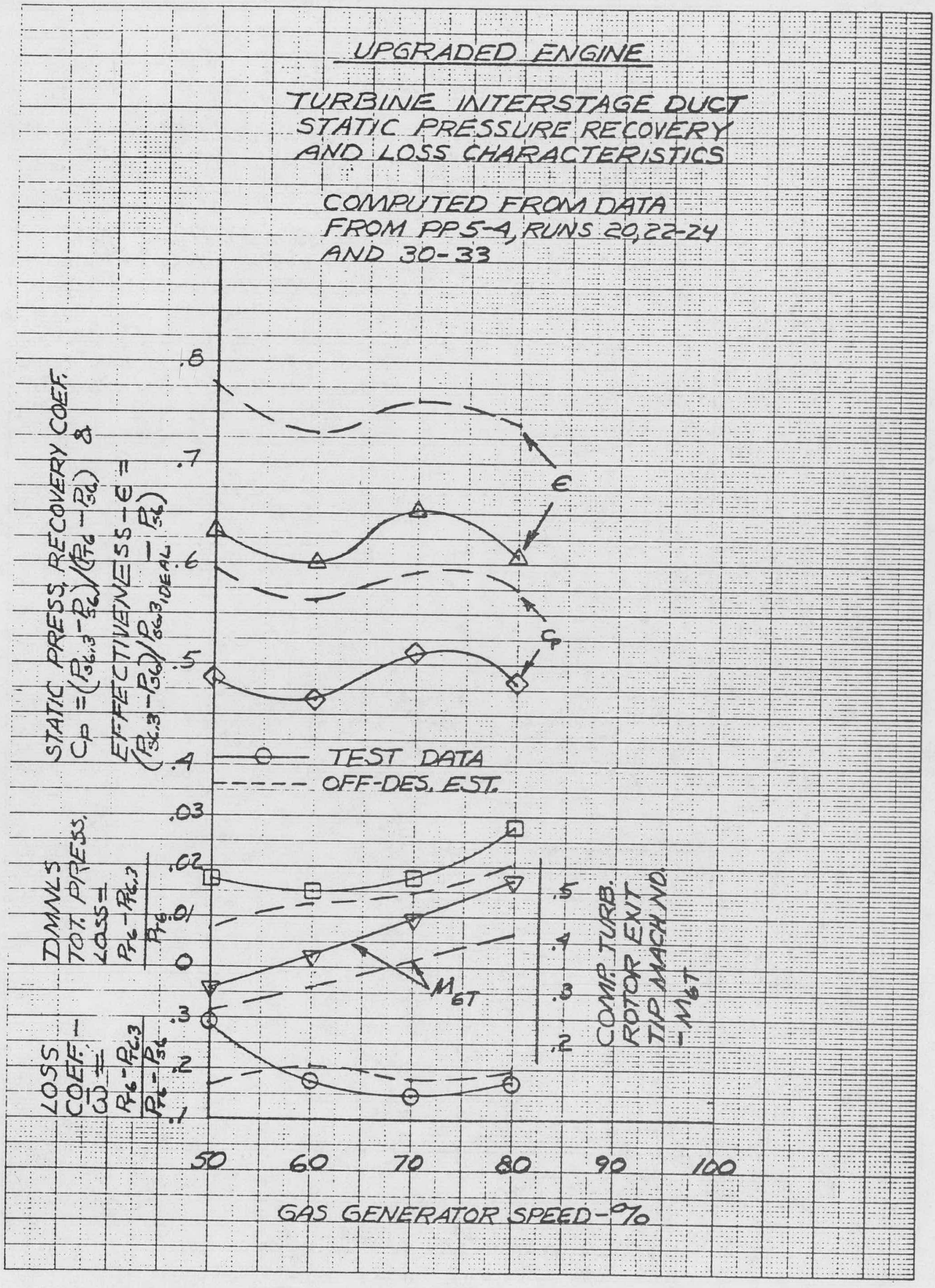




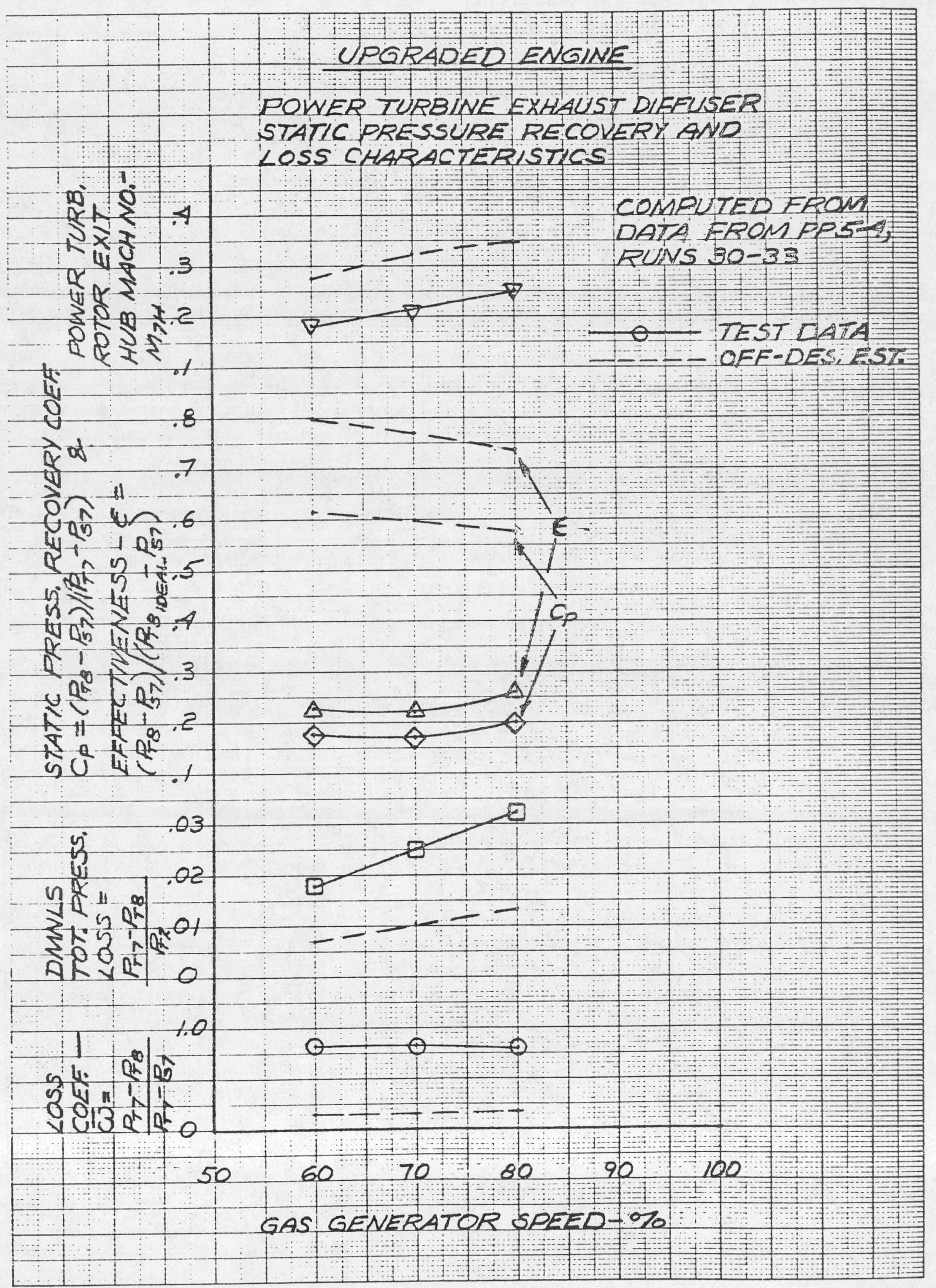




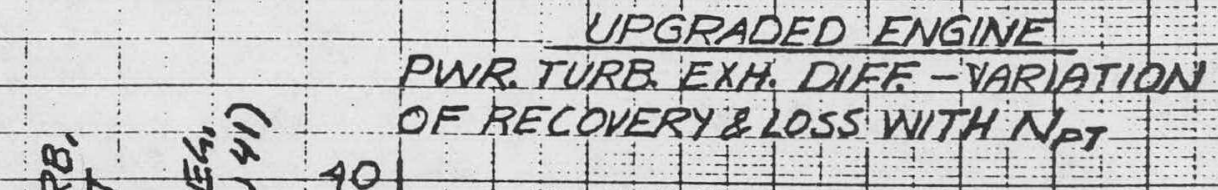

Q $3 \frac{1}{4} \cos ^{2} 40$

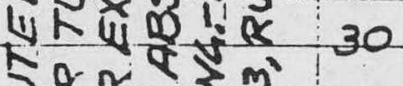

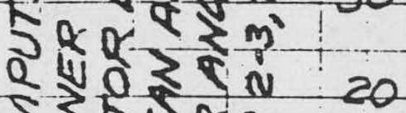

प0रे स⿺

m. $2: .4$

काषे

रㅏㄹ

कर

पx $x$

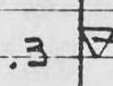

2

1

4

प्र क 11.6

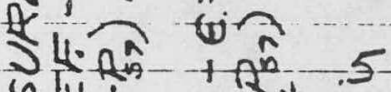

ज) 0 is

प.

सेति सू०

U1 से 3

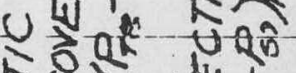

कe III 12 Su $\frac{4}{4} x^{\circ}$
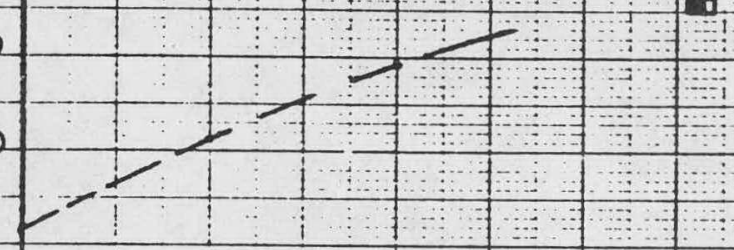

a.

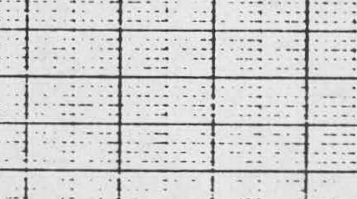




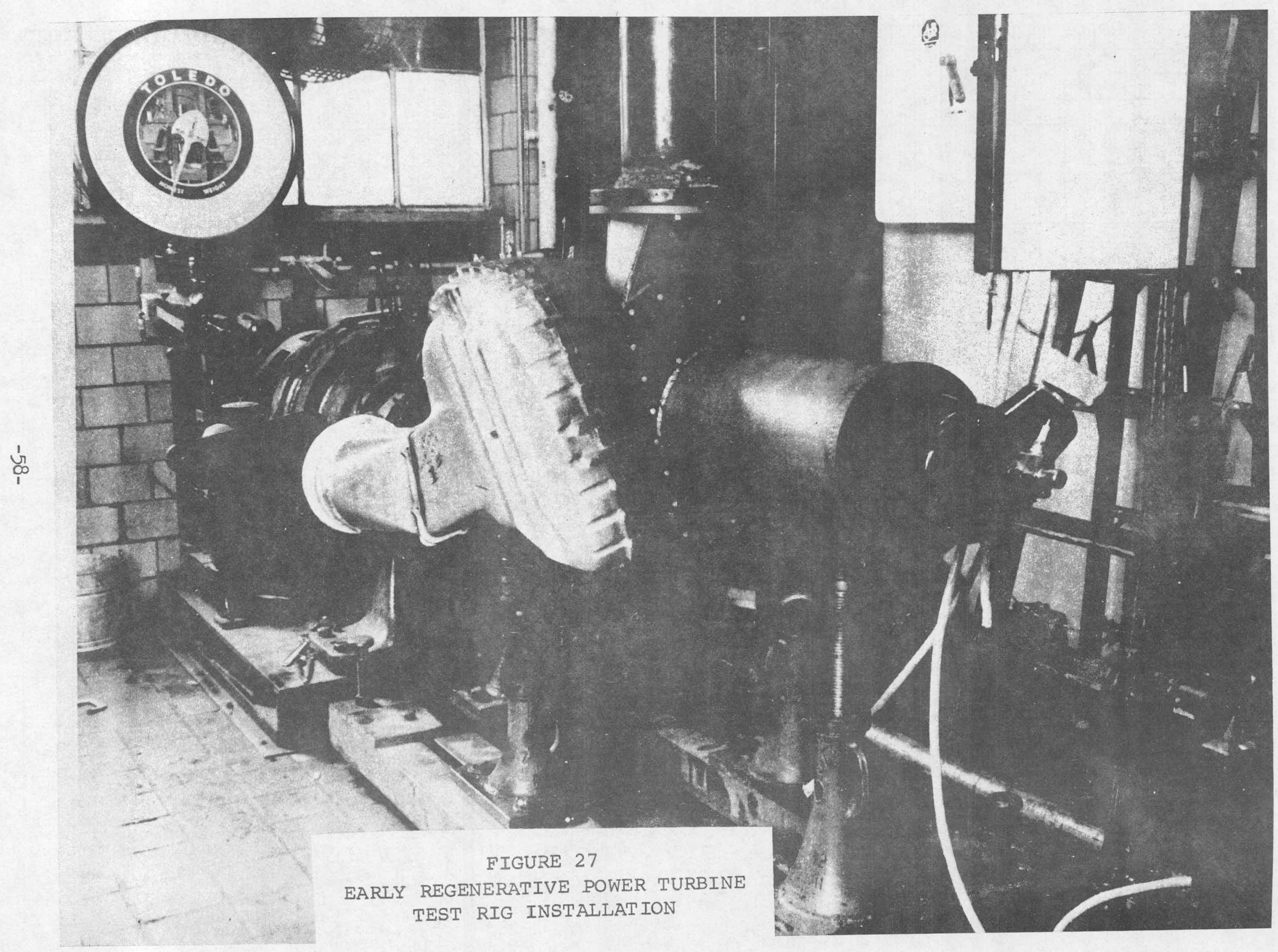




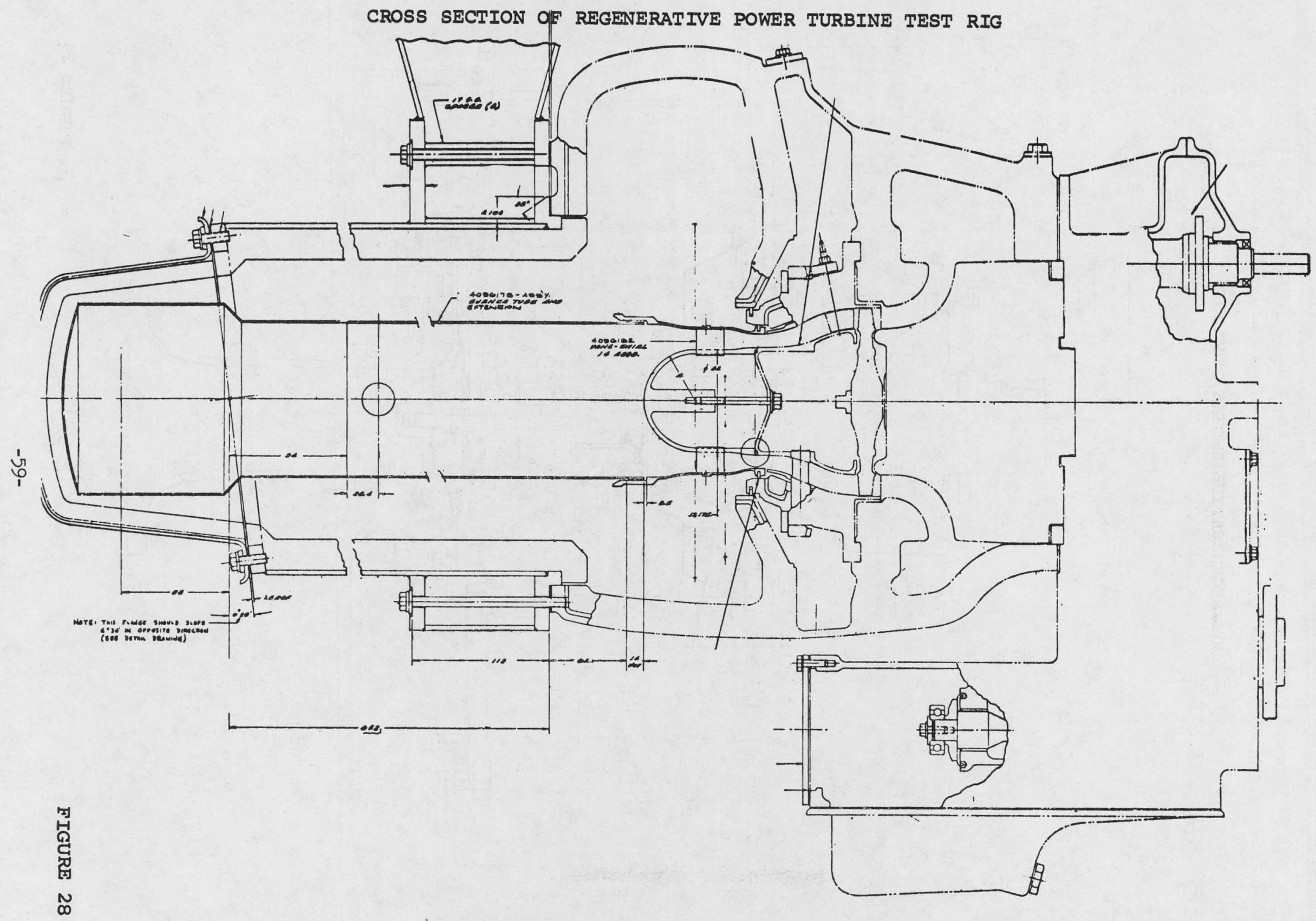


NON-REGENERATIVE ENGINE TEST RIG

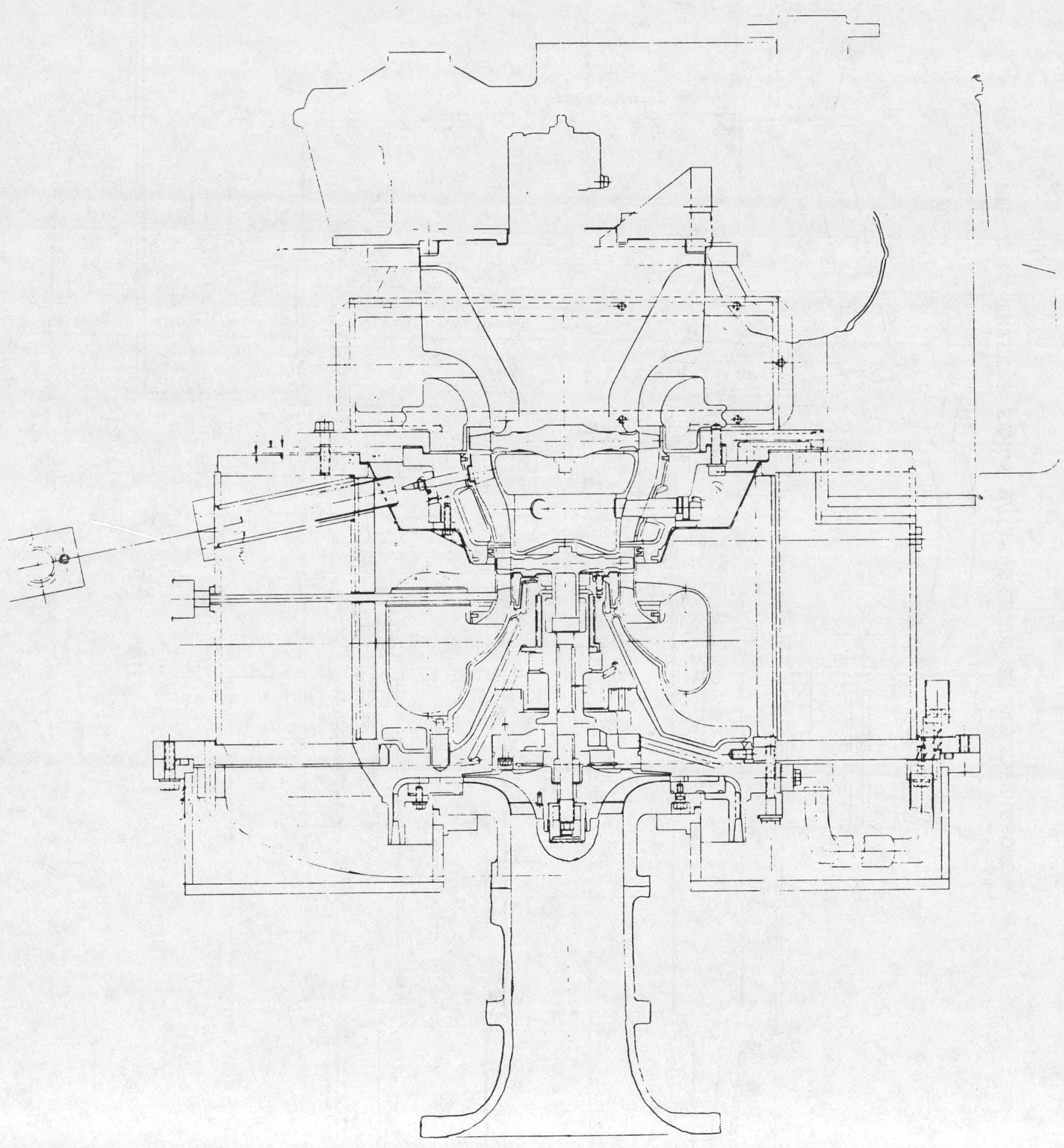




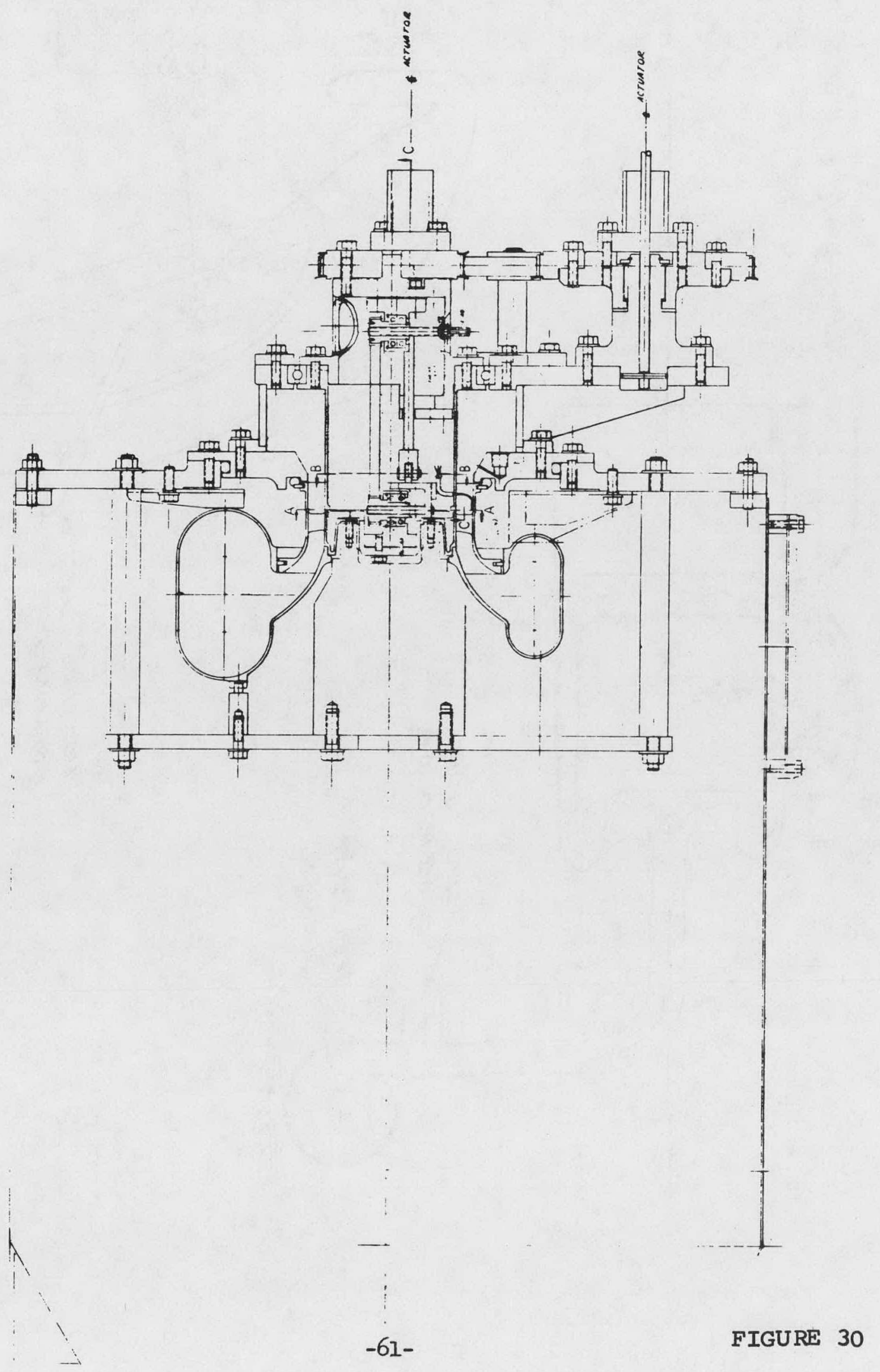




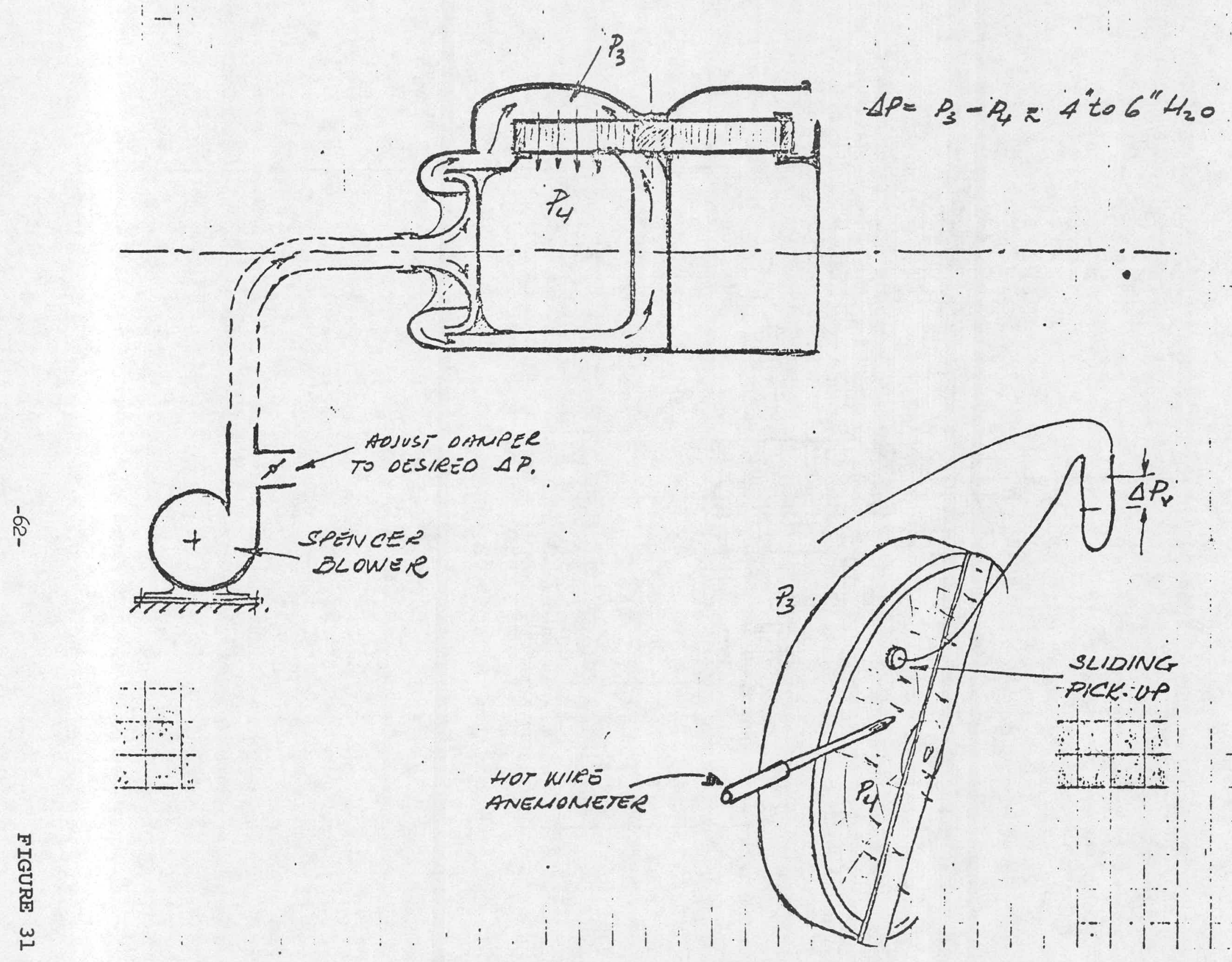

REGENERATOR FLOW DISTRIBUTION FIXTURE 


\section{UPGRADED ENGINE}

\section{LP REGENERATOR CORE \\ FLOW DISTRIBUTION}

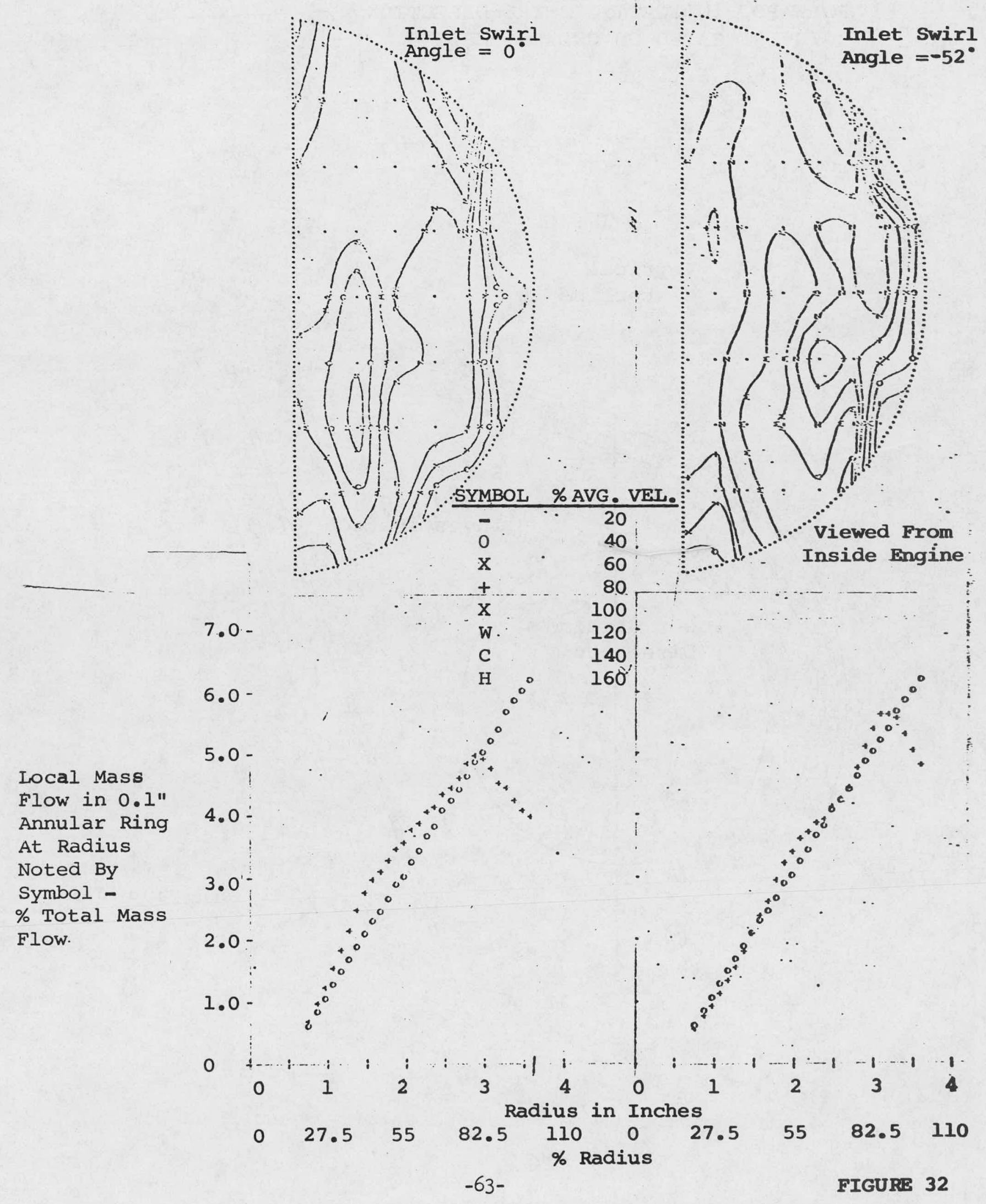


SECTION THROUGH EXHAUST COLLECTOR;

VIEW FROM REAR OF ENGINE LOOKING

FORWARD, INDICATING SWIRL DIRECTION

INVESTIGATED ON CREARE TESTING

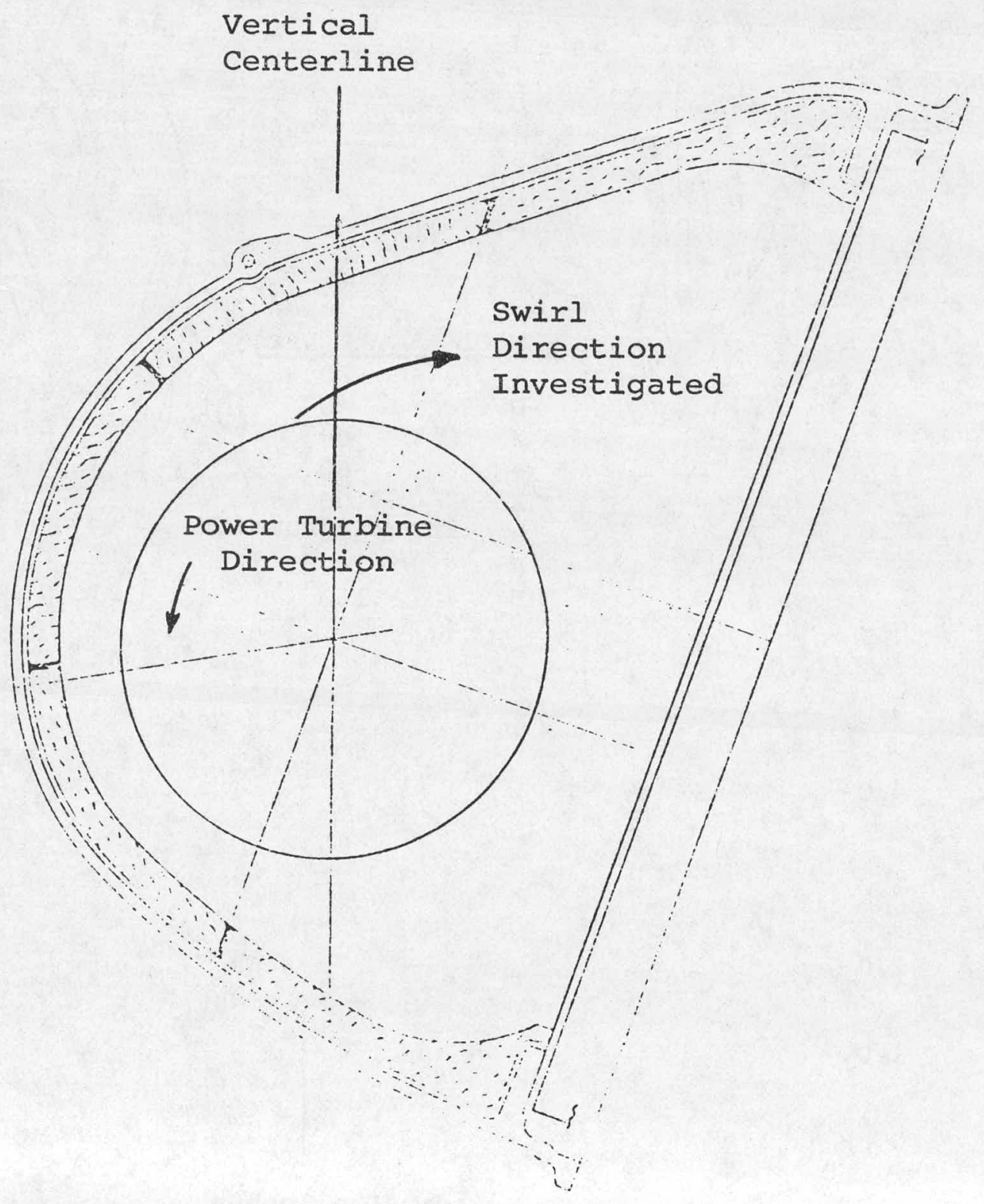




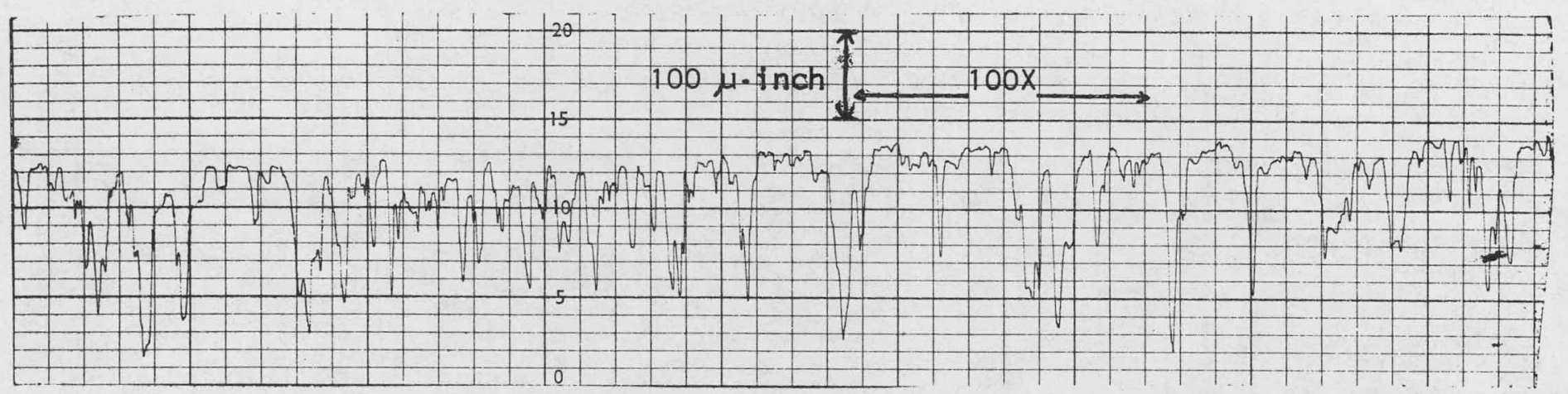

FIGURE (a): Vendor - Salerno Metal Spray; Microfinish - 22 to $30 \mu$ inch;

Part - Ground New Journal; Equipment - Metco 7M (80 KW)

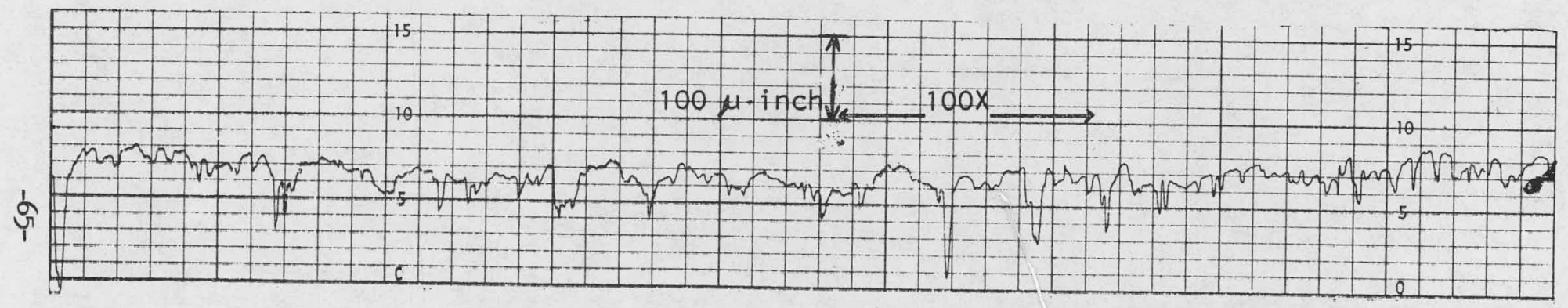

FIGURE (b): Vendor - Linde Div., Union Carbide; Microfinish - 14 to $15 \mu$ inch;

Part - Unworn section of used ground journal; Equipment - Detonation gun

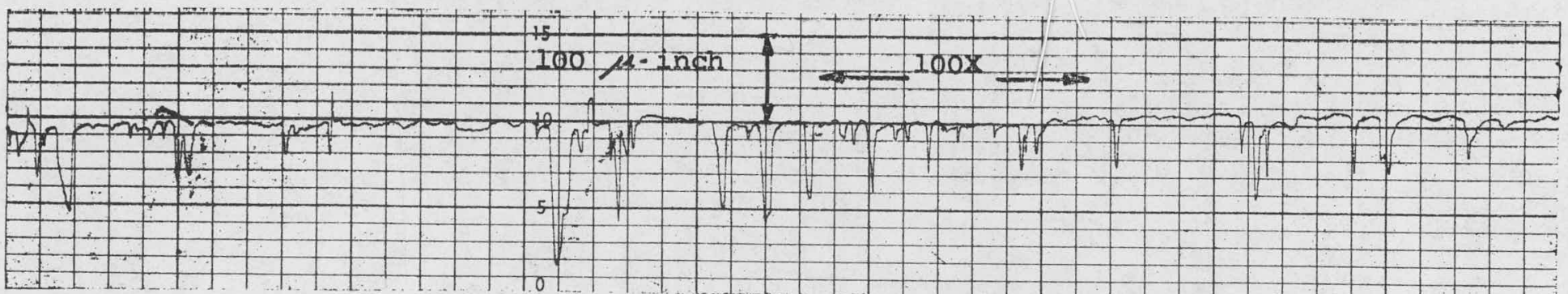

Source - Chrysler; Microfinish - 9 to $10 \mu$ inch;

Part - No. 3813804 - 10 (chg. B); reworned, ground journal;

Equipment - Plasmadyne SG-1B (4.0 KW) 

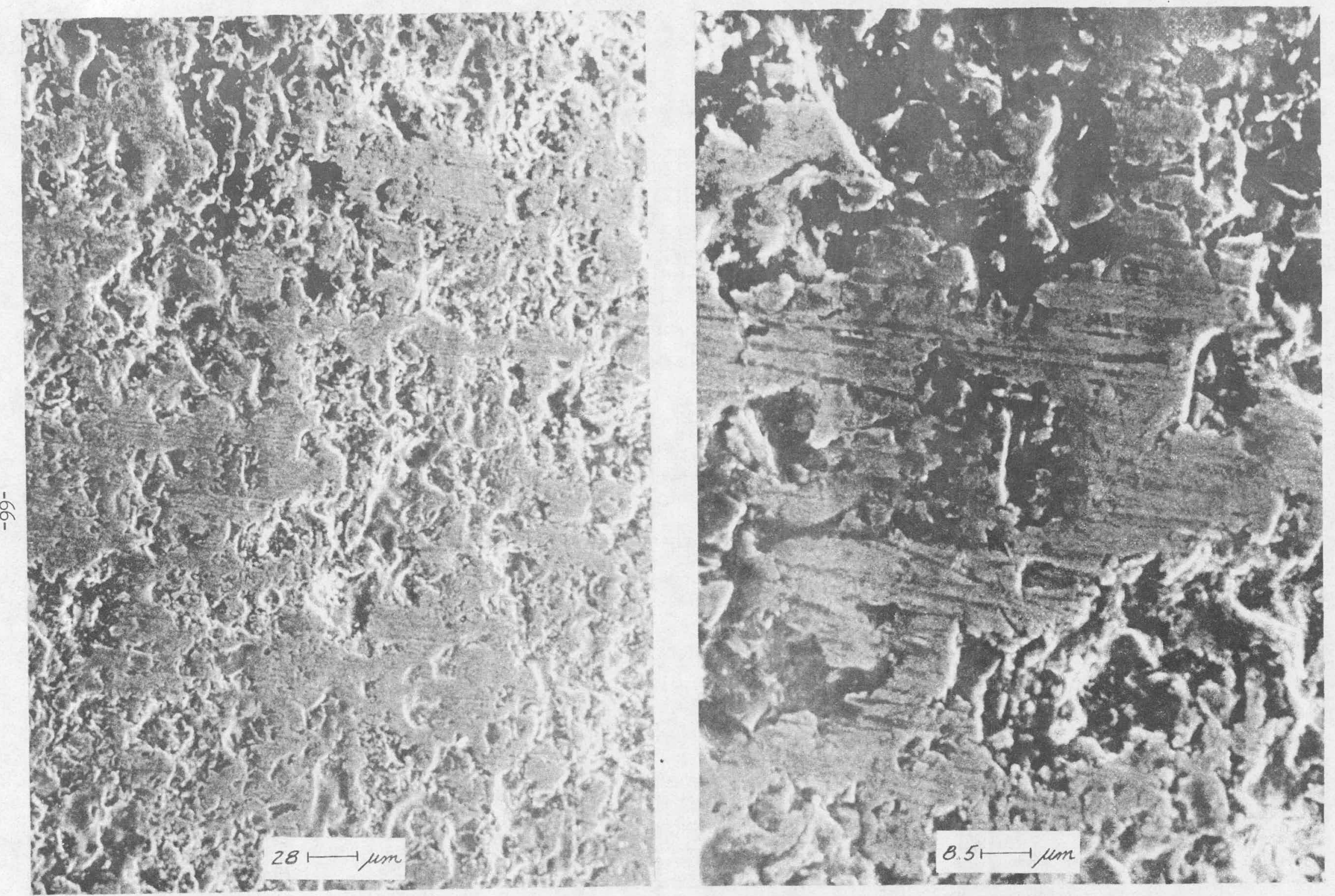

FIGURE 35

GAS BEARING JOURNAL SURFACE

SOURCE: CHRYSLER VENDOR; MICROFINISH: 22 TO $30 \mu$-INCH

PART: GROUND NEW JOURNAL; EQUIPMENT: METCO 7M (80 KW) 

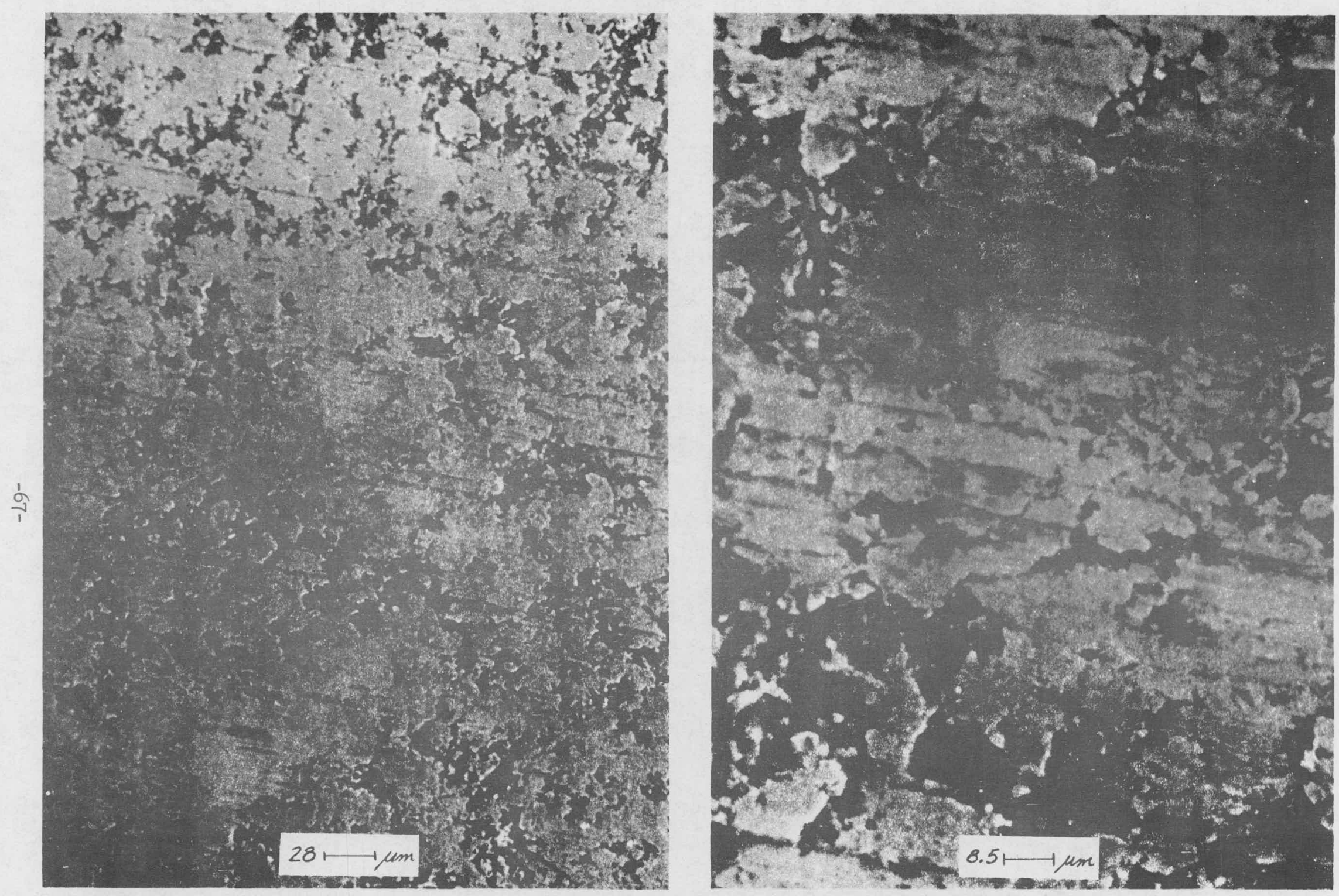

FIGURE 36

GAS BEARING JOURNAI SURFACE

SOURCE: MTI VENDOR; MICROFINISH: 14 TO $15 \mu$-INCH

PART: UNWORN SECTION OF USED GROUND JOURNAL; EQUIPMENT: DETONATION GUN 

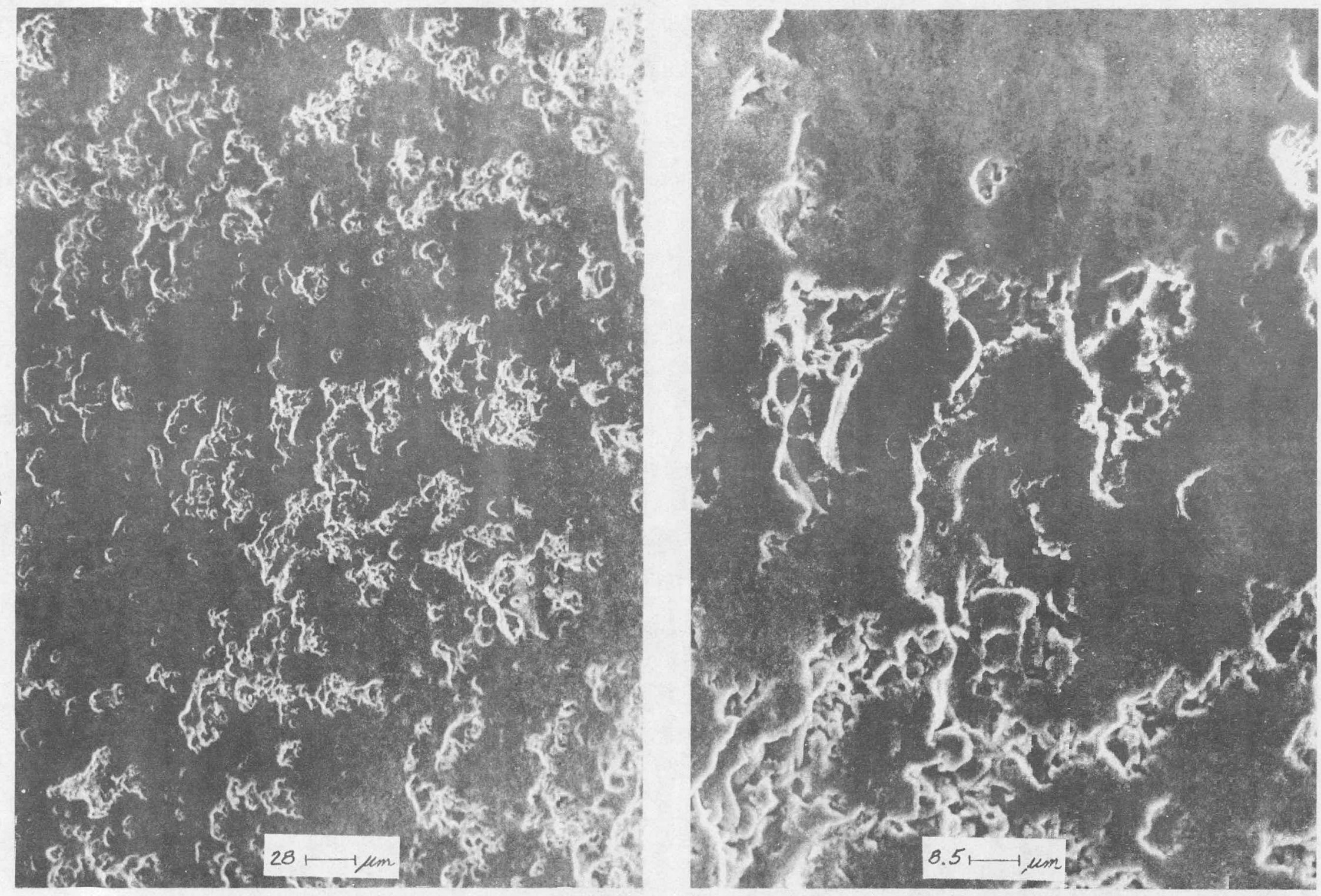

FIGURE 37

GAS BEARTNG JOURNAI SJRTACE

SOURCE: CHRYSLER; MICROFINISH: 9 TO $14 \mu$-INCH

PART: SAMPLE GROUND ON 600 GRIT SIC PAPER; EOUIPMENT: PLASMADYNE SG-1B (40 kiW) NEW 


\begin{tabular}{|c|c|c|c|c|c|c|c|c|c|c|c|c|c|c|c|c|}
\hline \multirow{2}{*}{ TASK/DESCRIPTION } & \multicolumn{8}{|c|}{1977} & \multicolumn{6}{|c|}{1978} & \multicolumn{2}{|c|}{ NOTE $\%$} \\
\hline & A & \multirow[t]{2}{*}{$\mathrm{J}$} & $\mathrm{J}$ & A & \multirow{2}{*}{$s$} & \multirow[t]{2}{*}{0} & \multirow[t]{2}{*}{$\mathrm{N}$} & \multirow{2}{*}{$\mathrm{D}$} & \multirow[t]{2}{*}{$\mathrm{J}$} & \multirow{2}{*}{ F } & \multirow{2}{*}{ M } & A & M & $\mathrm{J}$ & \# & $\operatorname{COMF}$ \\
\hline & & & & & & & & & & & & & & & & \\
\hline Task 1 Furnish 7 Baseline Engines & & & & & & & & & & & & & & & & 100 \\
\hline & & & & & & & & & & & & & & & & \\
\hline & & & & & & & & & & & & & & & & \\
\hline Task 2 Furnish 3 Turbine Powered Vehicles & & & & & & & & & & & & & & & & 100 \\
\hline & & & & & & & & & & & & & & & & \\
\hline & & & & & & & & & & & & & & & & \\
\hline Task 3 Provide Service \& Material Suppor $f$ & fof $\mathrm{Pr}$ & nogran & $m$ & & & & & & & & & & & & & 86 \\
\hline & & & & & & & & & & & & & & & & \\
\hline Task 3.1 Support to ERDA & 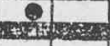 & & & & & 2 & & - & & & & & & + & 1 & 87 \\
\hline & & & & & & & & & & & & & & & & \\
\hline Task 3.2 a NASA Baseline Engine Support & & & & & & & & & & & & & & & & 100 \\
\hline & & & & & & & & & & & & & & & & \\
\hline Task $3.2 \mathrm{~b}$ NASA Upgraded Engine Support & & & & & & & & & $\square$ & & $\longrightarrow$ & 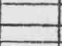 & 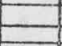 & $\$$ & & 32 \\
\hline & & & & & & & & & & & & & & & & \\
\hline & & & & & & & & & & & & & & & & \\
\hline Task 4 Baseline Engine Endurance Tests & & & & & & & & & & & & & & & & 100 \\
\hline & & & & & & & & & & & & & & & & \\
\hline & & & & & & & & & & & & & & & & \\
\hline Task 5 Component Development \& Evaluation & & & & & & & & & & & & & & & & 99 \\
\hline & & & & & & & & & & & & & & & & \\
\hline Task 5.1 through $5.7 \mathrm{a}$ and Task 5.8 through & 5.12 & & & & & & & & & & & & & & & 100 \\
\hline & & & & & & & & & & & & & & & & \\
\hline Task $5.7 \mathrm{~b}$ Continuously Variable Hydrome & tahica & $1 \mathrm{~T}$ & & & ion & & & & & & & & & & & 90 \\
\hline - Hydraulic Pump and Motor Design & & & & & & & & & & & & . & & & & 100 \\
\hline - Procure and Assemble & & & & & & & & & & & & & & & & 100 \\
\hline - Evaluate Hydraulic Unit at MTI & & & & & & & & & & & & & & & & 100 \\
\hline - Chrysler Evaluation and Transmission & Defin & gition & $\mathrm{n}_{3}$ & $\bar{f}$ & $\bar{P}$ & & & & & & & & & & & 80 \\
\hline - Transmission Analysis and Report & 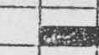 & 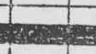 & & & & $\square$ & & & & & & & & & & 30 \\
\hline & & & & & & & & & & & & & & & & \\
\hline & & & & & & & & & & & & & & & & \\
\hline Task 6 Verify Task 5 Improvements in Vehi & icles & & & & & & & & & & & & & & & 100 \\
\hline & & & & & & & & & & & $:$ & & & & & \\
\hline & & & & & & & & & & & & & & & & \\
\hline Task 7 Furnish Upgraded Engines & & & & & & & & & & & & & & & & 77 \\
\hline & & & & & & & & & & & & & & & & \\
\hline Task 7.1 Design and Specify Upgraded Engir & ine & & & & & & & & & & & & & & & 100 \\
\hline & & & & & & & & & & & & & & & & \\
\hline Task 7.2-- Build and Checkout 10 Upgraded & d Engi & nes & & & & & & & & & & & & & & 83 \\
\hline - Frocure and Inspect Parts & ger & & & 8 & - & $\Rightarrow$ & & & & & & $\square$ & - & & & 90 \\
\hline - Build 10 Engines & 政 & & & & - & $\square$ & & & $\square$ & & & $\square$ & 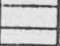 & $P$ & & 60 \\
\hline - Conduct Reference Tests & & & & & & & & & & 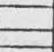 & & $\square$ & 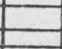 & & & 30 \\
\hline & & & & & & & & & & & & & & & & \\
\hline & & & & & & & & & & & & & & & & \\
\hline & & & & & & & & & & & & & & & & \\
\hline$\# 10=$ Major shows & & & & & & & & & & & & & & & & \\
\hline & & & & & & & & & & & & & & & & \\
\hline & & & & & & & & & & & & & & & & \\
\hline & & & & & & & & & & & & & & & & \\
\hline
\end{tabular}


BASELINE GAS TURBINE DEVEIOPMENT PROGRAM PLAN

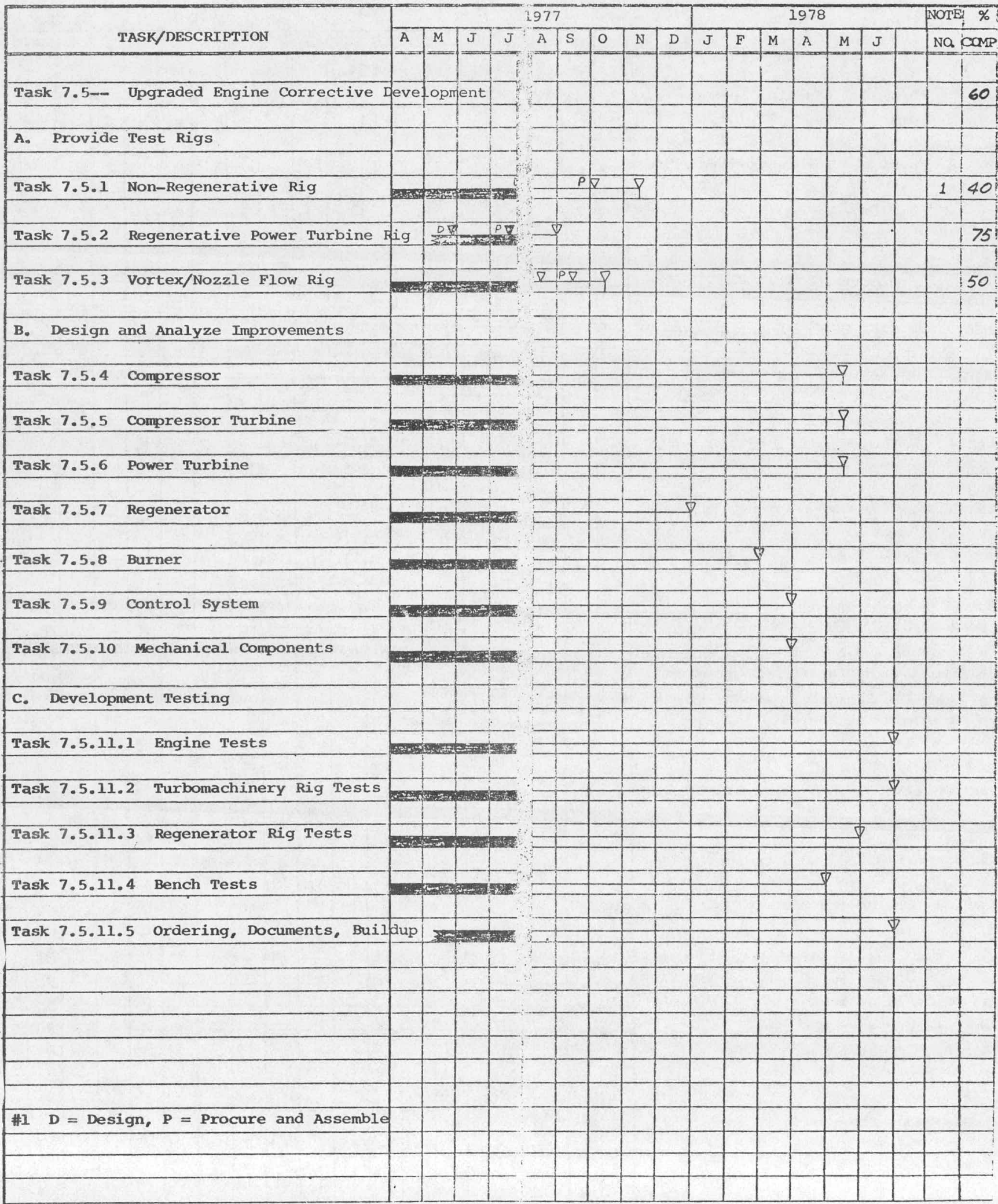


BASELINE GAS TURBINE DEV: OPMENT PROGRAM PLAN

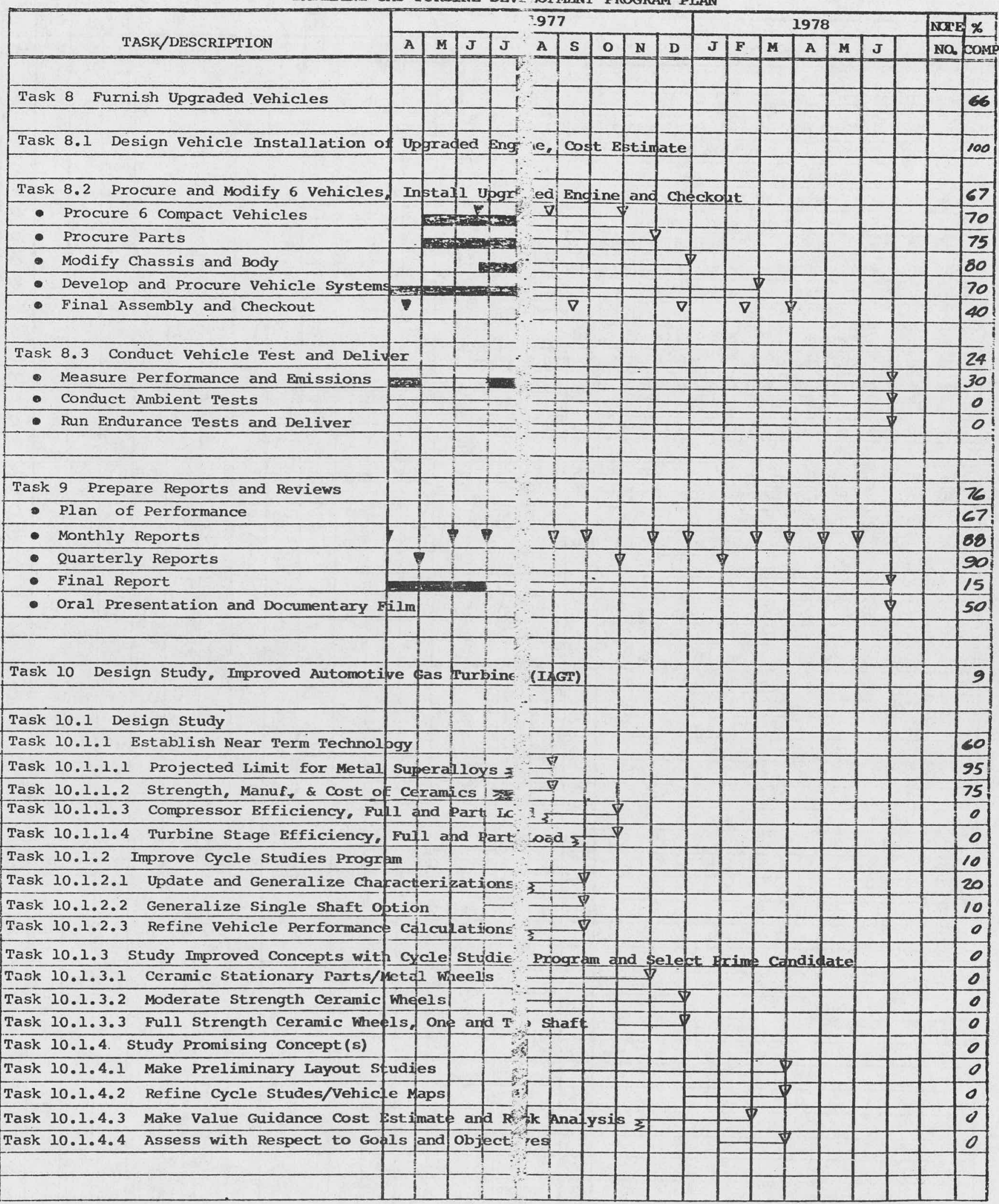


BASELINE GAS TURBINF, DEVELOPMENT PROGRAM PLAN

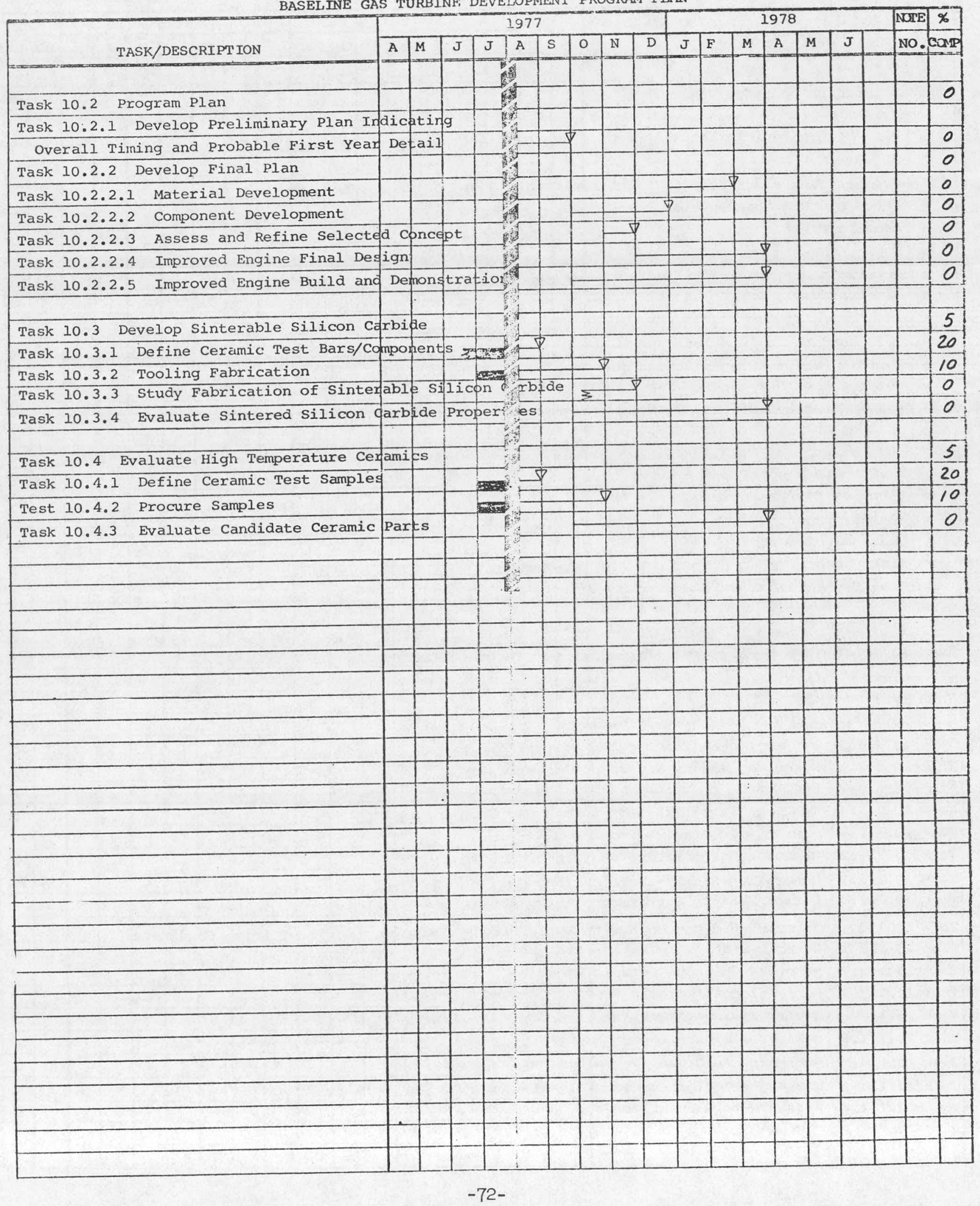

